UNIVERSIDADE de SÃO PAULO

Faculdade de Filosofia, Letras e Ciências Humanas

\title{
GIAMBATTISTA VICO:
}

sua proposta sobre o começo das civilizações e os

comentários rabínicos sobre o dilúvio universal.

Maria Angela Marini Esposito

Orientação: Profa. Dra. Vilma de K. Barreto de Souza

São Paulo

2007 


\section{Maria Angela Marini Esposito}

\section{GIAMBATTISTA VICO:}

sua proposta sobre o começo das civilizações e os

comentários rabínicos sobre o dilúvio universal.

Dissertação apresentada ao Programa de Pós- Graduação em Língua e Literatura Italiana do departamento de Letras Modernas da Faculdade de Filosofia, Letras e Ciências Humanas da Universidade de São Paulo, para obtenção do título de mestre em Letras. 


\section{Agradecimentos}

À Profa. Dout. Vilma de Katinszky Barreto de Souza que me aceitou como mestranda e, com muito tato e inteligência, indicou-me o caminho para que minhas idéias e aspirações se transformassem num trabalho acadêmico. E por ter me ensinado a amar a obra de Giambattista Vico.

Ao Prof. Dout. Moacir Amâncio por ter acreditado no meu projeto, acompanhando-me e auxiliando-me nas pesquisas sobre literatura judaica.

À querida amiga e colega Rosa Caporrino, pela doçura e pelas indicações precisas e úteis nos momentos de crise.

À querida amiga Adriana Buarque que, no momento certo e com visão prática e didática, posicionou-me para que eu não me perdesse em idéias e divagações.

À aluna e amiga Renata Bulgheroni, pelo precioso auxílio de revisão, que me ajudou a não cometer tantos “italianismos”.

Aos meus pais pelo incentivo, por terem me ensinado a levar a sério todo tipo de trabalho e pelo precioso auxílio na administração familiar.

Ao meu irmão por me achar mais competente do que realmente sou, fazendo-me acreditar que valeria a pena seguir em frente.

Às minhas amadas filhas, Gianna, Giulia e a pequena Luisa, pelo companheirismo, pela ajuda e porque souberam ser pacientes e incentivadoras, respeitando minha ausência e meu confinamento durante o tempo de pesquisa.

E Àquele, a quem Vico reverenciou em seu trabalho acadêmico e a quem os judeus reverenciam em suas vidas. 


\section{RESUMO}

Esta pesquisa visa evidenciar as semelhanças existentes entre a proposta de Giambattista Vico sobre o começo das civilizações gentílicas e as argumentações rabínicas relativas ao episódio do Dilúvio Universal, narrado em Gênesis 6 e considerado um documento conservado pelas tradições orais e verbais judaicas. Buscamos os fundamentos da literatura grego-romana e judaica que levaram Vico a intuir um método para a verificação das ciências humanas. Tal método difere do método dedutivo, aclamado pelos intelectuais de sua época, pois o filósofo italiano acredita que a religião está presente na base do processo civilizatório e coloca a linguagem como o fenômeno que organiza o mundo. Levantamos - nos postulados viquianos e nas argumentações rabínicas relativas aos primeiros capítulos de Gênesis - as observações que apresentam as características intrínsecas que condicionam os homens a instituir os três princípios eternos (religião, casamentos e sepulturas), identificáveis na formação de todos os povos; situamos as três fases viquianas (divina, heróica e humana) nos textos judaicos e evidenciamos, na visão rabínica de mundo, os fundamentos usados como base para a formação do conceito viquiano sobre a graça; tal conceito é responsável pela divisão da humanidade entre hebreus e gentios e dá margem às conjecturas relativas à existência de gigantes no tempo do dilúvio.

Palavras chave: $\quad$ Vico - Dilúvio - argumentações rabínicas - processo civilizatório Judeus 


\section{GIAMBATTISTA VICO: its proposal of the civilization beginning and the rabbinical arguments about the Universal Flood.}

\section{ABSTRACT}

This research aims to evidence the existing similarities between the proposal of Giambattista Vico about the beginning of the heathen civilization and rabbinic arguments about the episode of the Flood, in Genesis 6, considered a document conserved for Jewish oral and verbal traditions. We searched for the beddings of literature Jewish and Greek-Roman that allowed Vico to intuit a method for the verification of human beings sciences. Such method differs from the deductive method, acclaimed for the intellectuals of its time: the Italian philosopher believes that the religion is present in the base of the civilization process and places the language as the phenomenon that organizes the world. We showed - in the vichian postulates and the rabbinic arguments about the first chapters of Genesis - the comments that focus the intrinsic characteristics which induce the men to institute the three perpetual principles (religion, marriages and sepultures), identifiable in the formation of the nations everywhere; we pointed the three vichian phases (divine, heroic and human being) in the Jewish texts and we evidence, in the rabbinic view of world, the beddings used as base for the elaboration of the vichian concept about the favour; such concept is responsible for the division of the humanity between heathen and Hebrews allowing conjectures about the existence of giants in the time of the Flood.

Keywords: Vico - Flood - rabbinic arguments - civilization process - Jewish 


\section{CAPÍTULO I}

Fundamentos teóricos da teoria viquiana: a religião e a fantasia criadora na base do processo civilizatório.

$\begin{array}{lll}\text { I. } 1 \text { A metafísica de Vico } & 15\end{array}$

I. 2 O Dicionário Mental e os Poetas Teólogos 23

I. 3 A poesia e a religião: a teoria da graça e o sentimento do trágico

\section{CAPÍTULO II}

Os pressupostos viquianos e a literatura judaica: o modelo

Judaico de aculturação

II. 1 Um princípio civilizatório comum identificado na mitologia dos povos

II. 2 Do resíduo de textos sagrados 39

II. 3 A literatura judaica e as tradições Jawista e Elohista 41

II. 3.1 Da história da literatura e da cultura judaica 42

II. 3.2 Torá, Talmude, Midrash $\quad 45$

II. 3.3 O Midrash do dilúvio 48

\section{CAPÍTULO III}

A proposta viquiana sobre o começo das civilizações e os comnetários rabínicos sobre o dilúvio universal

III.1 O homem se relaciona com a divindade

III.2 Os pressupostos eternos ou características intrínsecas que conduzem o homem a empreender um começo civilizatório por meio da religião

III. 2.1 A capacidade de se comunicar, o caráter sociável, o livre-arbítrio e o senso comum

III.3 As civilizações se estabelecem a partir dos três princípios universais e eternos (religião,casamentos, sepulturas)

III. 4 A história se desenvolve por fases

III.5 A linguagem é o fenômeno que organiza o mundo 75 
ANEXO A

G.Vico - La Scienza Nuova - “Idea dell’opera” - pg 13/14/15

ANEXO B

Bíblia Sagrada - Gênesis 6: 1-12 59

84

ANEXO C

Midrash Rabá - Bereshit (Genesis) XXVI: 6:1

85

BIBLIOGRAFIA

86 


\section{Giambattista Vico: sua proposta sobre o começo das civilizações e os comentários rabínicos sobre o dilúvio universal}

\section{INTRODUÇÃO}

Giambattista Vico $^{1}$ é reconhecido como um dos nomes mais representativos da italianidade; sua obra máxima, $A$ Ciência $\mathrm{Nova}^{2}$, é o resultado de um trabalho pioneiro que vincula conceitos filosóficos, filológicos, religiosos e jurídicos em função da história. Vico investiu na pesquisa de documentos antigos, contrariando a expectativa de seu tempo, fortemente voltada para as comprovações científicas de tipo matemático: partindo de pressupostos metafísicos e adotando critérios próprios para a validação das ciências humanas, Vico propõe inúmeros temas que hoje são investigados e discutidos. ${ }^{3}$

Nosso campo de atuação tem sido o ensino da língua, arte e cultura italiana e Giambattista Vico sempre foi um dos nossos objetivos de estudo. Nossa modesta experiência limitava-se ao conhecimento de alguns aspectos da teoria viquiana e, ao ingressarmos no curso de Pós-Graduação, sem ter ainda um projeto de pesquisa, optamos por mergulhar no universo intelectual do filósofo napolitano. Estudar Vico leva a uma reflexão abrangente que contempla diferentes frentes de trabalho ${ }^{4}$; o filósofo e filólogo napolitano entrelaça teorias e conceitos importantes, diretamente voltados aos nossos focos de interesse.

\footnotetext{
${ }^{1}$ Giambattista Vico, filósofo, jurista e lingüista do séc. XVII/XVIII. Sua obra principal, $A$ Ciência Nova, elabora um começo para a história da humanidade que caminha em direção oposta ao cientificismo de sua época. Usaremos para indicá-lo, daqui por diante, a sigla GV ou simplesmente Vico.

2 Utilizaremos as citações viquianas do livro "La Scienza Nuova" - giusta ed. Del 1744 - Ed.Laterza - 1974. Fizemos as traduções e colocamos os trechos originais nas notas de rodapé.

${ }^{3}$ Acessando a Internet, podemos encontrar os Centros de estudos viquianos, espalhados pelas capitais do mundo.

${ }^{4}$ Durante o curso de especialização (1981/82) com o Professor Carlo Ludovico Ragghianti (1910-1987 Professor e crítico de Arte, fundador da U.I.A. - Universitá Internazionale dell'Arte em Florença) fomos motivados a conhecer as posições viquianas relativas à estética, sem, contudo visualizarmos o universo da Ciência Nova como um todo. As perguntas e incertezas desse período juvenil encontram respaldo nos dias de hoje, à medida que aprofundamos nossos conhecimentos sobre história da arte, sobre a Bíblia e sobre língua e cultura italiana.
} 
Durante o curso "A História e o mito na poética de Giambattista Vico" 5 chamou-nos a atenção o fato de Vico colocar o mito e a palavra no cerne do fato histórico, elegendo, dentre as obras de Platão, Aristóteles, Santo Agostinho e outros, a Bíblia como documento fundamental para explicar o início das civilizações. O filósofo aceita o pressuposto de que na terra paradisíaca de Adão nunca chovera ${ }^{6}$ até que as águas torrenciais da catástrofe diluviana inundaram a terra, ocasionando o aparecimento do raio, que Vico explica como "materie ignite, in aria, a ingenerarvisi i fulmini" " 7 . O mito criado em torno do fenômeno elétrico teria dado origem aos inúmeros Joves ${ }^{8}$, presentes nas fábulas de diferentes povos antigos; para Vico, a existência de tantas fábulas antigas a respeito do dilúvio não só demonstra que os povos registram sua história física como atestam que as águas teriam coberto toda a face da terra. O relato bíblico da catástrofe seria mais um dentre tantos registros, e nele Vico situa um começo para os gentios e uma continuação para os hebreus.

Vico acredita que todas as histórias gentílicas têm "favolosi principi” e que o povo hebreu teria sido o único a não ter inventado com "le favole" - isto é, com as fábulas - seu início histórico.

"[...] e para contemplar com razões também humanas todo o crivel cristão, que parte do seguinte princípio: que o primeiro povo do mundo foi o hebreu e seu príncipe foi Adão, o qual foi criado pelo Deus verdadeiro." 9

\footnotetext{
${ }^{5}$ Pós-graduação - Letras Modernas - Língua e Literatura italiana - USP - 2002 - ministrado pela Profa. Dout. Vilma de K.B. de Souza.

${ }^{6}$ Gen 2:5: "... porque ainda o Senhor não tinha feito chover sobre a terra... um vapor, porém, subia da terra... ”ALMEIDA, João Ferreira de - "Bíblia Sagrada” - Florida, Ed. Vida, 1990. Utilizaremos as citações bíblicas dessa edição.

${ }^{7}$ Isto é, material advindo de exalações secas que pudessem gerar o fenômeno ígnio do raio, que B.Franklin, em 1752 explicaria como descarga elétrica. - La Scienza Nuova - Lib. I - Sez II - Degli Elementi - pag. 109

8 "175 Varrão teve a diligência de recolher trinta mil nomes de deuses (e outros tantos foram encontrados entre os gregos) nomeados de acordo com cada necessidade da vida natural, moral, economica ou civil dos primeiros tempos”- La Scienza Nuova - Livro I. Sez. II- Degli Elementi - pag. 105.

9 “51 [...] e per assistere con ragioni anco umane a tutto il credibile cristiano, il quale tutto incomincia da cio: che 'l primo popolo del mondo fu egli l'ebreo, di cui fu principe Adamo, il quale fu creato dal vero Dio con la criazione del mondo. “ - La Scienza Nuova - Lib. I - Sez. I - Annotazioni alla tavola cronologica nelle quali si fa l'apparecchio delle materie - pag. 51
} 
Na teoria viquiana, a criação da terra e da humanidade está vinculada à existência de um Deus verdadeiro, identificado na Torá, o livro sagrado dos judeus.

"Estas são as origens dos céus e da terra, quando foram criados; no dia em que o Senhor Deus fez a terra e os céus, e soprou em suas narinas o fôlego da vida; e o homem foi feito alma vivente.

"E plantou o Senhor Deus um jardim no Éden, do lado oriental; e pôs ali o homem que tinha formado." 10

Vico situa nos capítulos anteriores ao Gênesis 6 os pressupostos universais e eternos com os quais Deus teria capacitado a humanidade representada em Adão: a habilidade de se comunicar e de se relacionar com a divindade por meio de leis são requisitos do primeiro homem e a história dos inícios, contada no relato bíblico mediante "caracteres poéticos", serve de base para que o filósofo elabore sua teoria sobre a "graça" ${ }^{11}$, na qual o Deus da criação não é um mito ou um deus inventado; na história das civilizações gentílicas, que aparecem depois do dilúvio, a escolha dos descendentes de Noé de viverem num esquema “fora da graça” dá início a novas religiões: no exercício do livre arbítrio (um dos pressupostos eternos e universais da teoria viquiana ${ }^{12}$ os homens puderam optar por uma organização diferente daquela proposta pelo Deus de Adão:

"[...] num longo espaço de anos as raças impias dos três filhos de Noé prosseguiram num estado ferino e divagando se afastaram e espalharam-se pela grande selva da

\footnotetext{
${ }^{10}$ Gênesis 2 : 7-8 - Bíblia Sagrada .

11 Durante sua estadia em Vatolla, Vico aprofunda seus conhecimentos sobre leis e direito canônico, relacionando-os à graça; a meditação viquiana relativa aos conceitos filosóficos e teológicos em torno da graça divina o conduz a desenvolver uma suspeita, porém admirável, pesquisa filológica, que culmina com a elaboração de sua teoria sobre o direito natural das gentes. Seus estudos tomam por base a teoria da graça meditada sobre o texto de Gênesis, possivelmente enriquecida com análises rabínicas e midrashicas.

${ }^{12}$ No capítulo I deste trabalho falaremos dos pressupostos eternos a que se refere GV.
} 
terra, e com a educação ferina (selvagem) puderam desenvolver-se, tornando-se gigantes, no tempo em que o primeiro raio fulminou o céu depois do dilúvio." 13

O capítulo 6 do Gênesis contém o relato do dilúvio universal e apresenta os efeitos da escolha de uma vida dentro e fora da graça num ambiente pré-diluviano:

"Viu o Senhor que a maldade do homem se multiplicara sobre a terra, e que toda a imaginação dos pensamentos de seu coração era má continuamente”. Então o Senhor arrependeu-se de haver feito o homem sobre a terra e isso lhe pesou no coração.

Disse o Senhor: Destruirei de sobre a face da terra o homem que criei, tanto o homem como o animal, os répteis e as aves do céu; pois me arrependo de havê-los feito.

Noé porém achou graça aos olhos o Senhor." 14

GV considera diferentes princípios que incluem o sobrenatural, a natureza física e o universo de pensamentos e crenças que povoam a mente dos homens em todos os tempos - e os reúne num único princípio: o "verum et factum convertutur "15; com ele, Vico cria um vínculo inexorável entre a verdade dos fatos - que produzem a história - e a criação de Deus que se faz continuamente. Deus é onisciente e onipotente enquanto criador do ser, mas a história é objeto de conhecimento do homem porque é ele quem a faz ${ }^{16}$; e a faz com idéias, registros e palavras. É assim que a Ciência Nova aparece como a primeira ciência a garantir a autoridade da filosofia com a filologia e vice-versa.

\footnotetext{
13 “195 [...] dentro tal lunghissimo corso d'anni le razze empie degli tre figliuoli di Noé fussero andate in uno stato ferino, e con un ferino divagamento si fussero sparse e disperse per la gran selva della terra, e con l'educazione ferina vi fussero provenuti e ritruovati giganti nel tempo che la prima volta ful minò il cielo dopo il diluvio.” - La Scienza Nuova - Livro I. Sez. II- Degli Elementi - pag. 109.

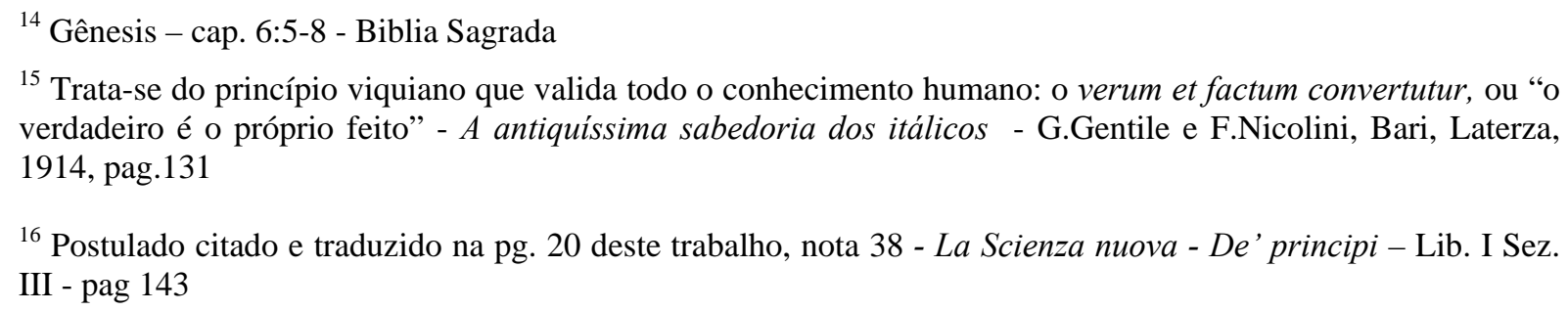
verdadeiro é o próprio feito” - A antiquíssima sabedoria dos itálicos - G.Gentile e F.Nicolini, Bari, Laterza, 1914, pag.131

${ }^{16}$ Postulado citado e traduzido na pg. 20 deste trabalho, nota 38 - La Scienza nuova - De’ principi - Lib. I Sez. III - pag 143 
"A filosofia contempla a razão, de onde vem a ciência do verdadeiro (do que realmente aconteceu); a filologia observa a autoridade do arbitrio humano, de onde verificação do certo... Este mesmo axioma demonstra que aos filósofos faltou uma metade de conhecimento por não terem se certificado com a autoridade dos filólogos assim como os filólogos não tiveram o cuidado de tornar verdadeiras as suas colocações com a razão dos filósofos; e se ambos o tivessem feito teriam sido mais úteis às republicas e seríamos poupados de meditar esta Ciência." 17

Vico recolhe e digere as informações obtidas empreendendo um estudo aprofundado de lendas e fábulas, num tipo de trabalho que combina hermenêutica e filologia; essas ferramentas, nas mãos de exegetas da qualidade de GV, permitem que se imprima um nível de atenção à leitura que mais tarde poderá ser equiparado ao dos tradutores de textos considerados sagrados. O mesmo nível de atenção é encontrado nas argumentações rabínicas em torno da Torá, um dos livros sagrados ao qual Vico atribuiu valor de documento. Sua obra revela o esforço em visualizar a dinâmica dos fatos num período atemporal e, nesse tipo de trabalho, enxergamos uma semelhança com o modo de argumentar dos rabinos. Os comentários viquianos e rabínicos relativos à catástrofe diluviana (objeto de dissertação do capítulo III deste trabalho) apresentam um modo de investigar que parte de um exercício de ciência pura: as palavras criam o contexto filosófico e físico, fazendo com que as idéias fluam de modo a ampliar os conceitos que consideram apenas os princípios naturais para explicar os inícios da humanidade. As informações contidas no Midrash Rabá ${ }^{18}$ capítulo XXVI, que comenta o episódio bíblico do dilúvio, permitem supor que Vico, assim como os rabinos, adotou o livro sagrado como uma fonte inesgotável de discussão: temas mitológicos, literários, históricos, jurídicos e religiosos são abordados, harmonizados e interpretados de

\footnotetext{
17 "138 La filosofia contempla la ragione, onde viene la scienza del vero; la filologia osserva l'autorità dell'umano arbitrio, onde viene la comienza del certo.....Questa medesima degnità dimostra aver mancato per metà cosí i filosofi che non accertarono le loro ragioni con l'autorià de' filologi, come il filologi che non curarono d'avverare le loro autorità con la ragio de' filosofi; lo che se avessero fato, sarebbero stati piú utili alle reppubliche e ci avvrebbero prevenuto nel meditare questa Scienza”. - Scienza Nuova - Livro I. Sez.II Degli Elementi - pag. 95

${ }^{18} \mathrm{O}$ capítulo II deste trabalho fornece os dados de nossa pesquisa sobre literatura judaica, estudados durante os cursos: "Introdução à visão talmúdica do mundo", ministrado para a Pós-Graduação USP pelo prof. Dout. Moacir Amâncio e "História dos tempos bíblicos", ministrado pela prof dout. Ruth Leftel (Letras Orientais 2003 e 2006).
} 
modo a corroborar o texto bíblico. Vico e os mestres da literatura rabínica não se concentram no fato, mas em como ocorre o fato e, para tanto, procuram "il vero" (a verdade) na filosofia e "il certo" (a certeza) que o processo lingüístico pode fornecer através da pesquisa filológica.

Neste trabalho apresentaremos nossa pesquisa referente aos critérios usados por Giambattista Vico para eleger o capítulo 6 do Gênesis como o marco que dá início às civilizações gentílicas. Evidenciaremos a postura metafísica e científica de Vico com relação à religião e aos registros lendários conservados desde os tempos por ele considerados "obscuros" e avaliaremos a história e os mecanismos de conservação da memória do povo hebreu que, de acordo com Vico, possui a mais antiga das tradições e uma teofania privilegiada com relação à dos outros povos. Nossa pesquisa levanta as colocações viquianas e rabínicas que apresentam a religião e a linguagem como fatores de aculturação e evidencia a semelhança entre o método de argumentação do filósofo italiano e o método perpetuado pelos mestres da literatura rabínica, apresentando também a semelhança de conteúdo existente entre os postulados viquianos e talmúdicos, relativos à formação das civilizações, à existência de um Deus revelado e à criação de deuses inventados.

O filósofo avalia, ao longo de sua obra, a origem das religiões, das falas e das leis, considerando a fase adâmica e estabelecendo, a partir daí, as diferenças entre a visão judaica e a gentílica, que se formaria numa fase pós-diluviana. Vico vincula o judaísmo a um tipo de visão de mundo que se apóia na "graça" e nas leis da Torá, enquanto a cultura ocidental seria plasmada por um tipo de visão fatalista: no início das civilizações que se formariam a partir de Sem, Cam e Jafet, o filósofo identifica os princípios fisiológicos e metafísicos que regem a humanidade desde sempre e os princípios religiosos e jurídicos que separam o povo hebreu dos demais povos que se formaram na terra. Ao adotar livros sagrados como documento, identificando nos mitos e nas lendas o fundo de verdade no qual se apóia o fato histórico, Vico traz à luz os critérios de estudo que seriam adotados para as disciplinas humanas que fariam parte do universo de matérias tais como as conhecemos hoje. 


\section{A distribuição do trabalho}

Dispomos nosso trabalho em três capítulos, procurando evidenciar os pontos do pensamento viquiano e rabínico que revelam afinidades, no que se refere à proposta sobre o início da humanidade e o início das civilizações.

O capítulo I terá como tema principal os fundamentos da teoria viquiana que situam a religião e o fenômeno lingüístico na base do processo civilizatório, focalizando o aspecto metafísico de sua proposta e a importância que as tradições orais e verbais judaicas exerceram na formação do pensamento viquiano. Citaremos as colocações de Umberto Eco ${ }^{19}$ e Walter Benjamin $^{20}$ para a base teórica que explica o criacionismo científico de Vico e a função da linguagem no processo civilizatório da humanidade desde a fase adâmica, na qual o filósofo identifica a "sabedoria poética e a lógica poética”. Apresentaremos os postulados viquianos referentes à formação da linguagem dos homens nas diferentes idades (divina, heróica e humana) e sua teoria sobre o aparecimento dos poetas teólogos, para relacioná-los com os registros históricos que revelam o mais antigo método de conservação da memória fundado pelos hebreus. Focalizaremos as visões judaica e trágica do mundo sob a ótica de George Steiner $^{21}$, vinculando-as ao conceito viquiano e rabínico de "graça” - que estabelece a diferença fundamental entre a civilização hebraica e a gentílica.

No capítulo II deste trabalho o tema fundamental versará sobre os aspectos da literatura judaica, que identificam a Torá e o Talmude como seus livros fundamentais e o Midrash como a expressão poética ou espiritual do pensamento judaico. Apresentaremos nossa pesquisa relativa ao método de conservação da memória, consagrado pelos judeus ${ }^{22}$, cujos registros (relativos à catástrofe diluviana), avaliados sob a ótica histórica e midrashica,

\footnotetext{
19 Umberto Eco ( 1932- ). Doutor em semiótica, a estética medieval, a comunicação de massa, a lingüística e a filosofia. - Consideraremos as citações do livro “Teorie contemporanee della traduzione” - Siri Nergaard,1995

${ }^{20}$ Walter Benjamin (Berlim 1892 -1940). Filósofo crítico das técnicas de reprodução em massa da obra de arte. Consideraremos as citações do livro “Teorie contemporanee della traduzione” - Siri Nergaard,1995

${ }^{21}$ George Steiner (1929 - ～）, atualmente professor de literatura comparativa ( Oxford); ensinou em Harvard e Cambridge. Consideraremos as citações do livro “A morte da tragédia” - Faber e Faber, 1961.

${ }^{22}$ Para essa pesquisa nos servimos dos conceitos e da bibliografia fornecida durante os cursos feitos junto ao Centro de estudos judaicos da USP.
} 
serviram de base para que Vico adotasse o episódio como um marco para o início da civilização gentílica. Apresentaremos os critérios lingüísticos para a verificação científica de textos antigos e sagrados, avaliando as teorias de Eugène Nida ${ }^{23}$ sobre o outro cultural e resíduo da mensagem que se preserva no tempo. Falaremos do "modus operandi" de Vico,

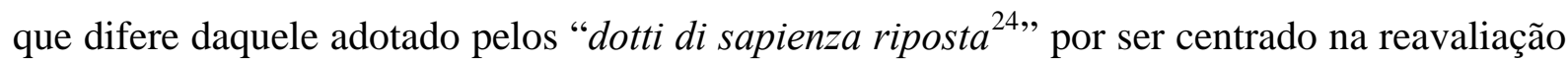
da mensagem residual de textos antigos e na adoção da filologia como instrumento de certificação, com o qual rabinos e tradutores de textos sagrados e antigos também trabalharam.

No capítulo III apresentaremos como tema fundamental as evidências que encontramos na proposta de Vico para o início da humanidade e as análises rabínicas presentes no Midrash Rabá XXVI relativas ao Gênesis 6: 1-11. Indicaremos as colocações metafísicas de Vico, que apresentam semelhanças com o conteúdo cosmogológico judaico, expresso nos textos da Torá e nos comentários talmúdicos ${ }^{25}$. Confrontaremos os postulados viquianos que falam das características intrínsecas do homem, que culminam com a proposta da divisão da humanidade entre hebreus e gentios; de tais características (que Vico chama de pressupostos) surgem os princípios que conduzem o homem a empreender um começo civilizatório por meio da religião. Situaremos os princípios viquianos (religião, matrimônios e sepulturas) e as fases viquianas (divina, heróica e humana) nos textos judaicos, evidenciando a importância da linguagem como fenômeno desencadeante da história.

Tendo como base as colocações viquianas relativas ao início das civilizações, o relato bíblico que narra a catástrofe diluviana em Gênesis 6 e as relativas interpretações midrashicas, levantaremos algumas evidências que mostram as afinidades existentes entre a filosofia de Giambattista Vico e a visão talmúdica de mundo.

\footnotetext{
23 Eugène Nida - lingüista-antropólogo-missionário-tradutólogo dos anos 50. Consideraremos a bibliografia sugerida durante o curso de “Teoria da tradução” - Pós-Gradução USP - 2002 - ministrado pela Prof. Dout. Lucia Watagin.

${ }^{24}$ Expressão viquiana usada para classificar os “doutos de sabedoria re-elaborada”.

${ }^{25}$ Confrontaremos os postulados viquianos com alguns versículos do Gênesis e as relativas citações do Midrash Habbad. Nossos comentários serão enriquecidos com artigos e estudos pesquisados, tais como a metodologia de Bacon e artigos de especialistas como a Prof. Dout. Tiziana Portera.
} 


\section{CAPÍTULO I}

\section{Fundamentos teóricos da teoria viquiana: a religião e a \\ fantasia criadora na base do processo civilizatório.}

\section{1 A metafísica de Vico}

O interesse de GV por conceitos universais aparece desde sua juventude ${ }^{26}$ e sua obra como um todo se reveste de metafísica. A metafísica de Vico convive com um tipo de racionalismo diferente daquele pregado por seus contemporâneos: dos estudos filosóficos, religiosos e mitológicos, extrai o comportamento padrão do ser humano frente à divindade e intui uma "metafísica della mente”, presente nos homens de todos os tempos e todas as raças.

"Para encontrar tais naturezas das coisas (primitivas) procede esta Ciência com uma séria análise dos pensamentos humanos referentes às necessidades humanas ou utilidades desta vida, que são duas fontes perenes do direito natural das gentes, como já se disse nos axiomas. Portanto, outro principal aspecto desta Ciência é ser uma história das idéias humanas sobre a qual deve proceder a metafísica da mente humana." 27

Vico acredita que, desde aquilo que ele próprio chama de primeira barbárie - um momento em que o ser humano vive num ambiente selvagem e num estágio “incivilizado”- o homem seja induzido a se comunicar com a divindade; assim sendo, conhecer a "metafisica della mente" significa ter acesso às idéias desses homens. O filósofo afirma que a religião estaria à base do processo civilizatório, não sendo, portanto, um fenômeno presente apenas nas sociedades desenvolvidas. Para Vico, todos os povos apresentam um começo civilizatório e nele existe a concepção de uma divindade: essa é a base ontológica que conduz o filósofo a definir sua ciência como uma “teologia civile ragionata della provvedenza divina":

\footnotetext{
26 “Opere” - revisão de Fausto Nicolini - Milão, 1953 - páginas iniciais da Autobiografia .

27 "347 Per andar a truovare tali nature di cose umane procede questa Scienza con una severa analisi de' pensieri umani d'intorno all'umane necessità o utilità della vita socievole, che sono i due fonti perenni del diritto natural delle genti, come pure nelle Degnità si è avvisato. Onde, per quest'altro principale suo aspetto, questa Scienza è una storia dell'umane idee, sulla quale sembra dover procedere la metafisica della mente umana.”La Scienza Nuova - Lib. I - Sez. VI - Del método - lib I . sez. IV - pág 150
} 
"Portanto esta Ciência, por um de seus aspectos principais, deve ser uma teologia civil raciocinada da providência divina, a qual parece ter faltado até agora, porque os filósofos ou a desconheciam, como os estóicos e epicuristas que dizem ser um concurso cego de átomos ou uma cadeia de causas e efeitos que conduzem as atitudes dos homens, considerando assim somente a ordem natural das coisas, onde "teologia natural" eles chamam de metafisica e com ela contemplam os atributos de Deus, confirmando-as com somente a ordem fisica..." 28

GV acredita que, movido por uma curiosidade inata, o homem procura entender os fenômenos circunstantes e, no anseio de comunicar as imagens e sensações que povoam sua mente, põe em ato a provvedenza divina - que procede do verbo divinare ou adivinhar. $\mathrm{O}$ processo mental - desprezado pelos naturalistas - só se concretiza quando o ser humano se expressa, e quando o faz deixa indícios ou sinais sensíveis, que comprovam sua capacidade de pensar "falando". Vico elabora seu estudo científico avaliando as marcas deixadas pelos homens e identifica pressupostos eternos e universais num ser ferino que se relaciona com as entidades que mitifica; os seres humanos, interagindo com seus mitos, dão seus primeiros passos em direção a algum tipo de organização social e é por essa razão que o filósofo define sua teologia como "teologia civil". Empreendendo o caminho oposto ao de seus contemporâneos - basicamente estóicos e epicuristas, que encaravam, sobretudo, o aspecto "natural" da teologia - a nova arte crítica, a Ciência Nova, passa a ser a própria história, que vem à luz a partir do estudo exegético de livros sagrados e antigos. Os fatos reais - embutidos na maneira com a qual os homens deram forma às suas idéias falando - podem ser extraídos nas lendas e mitos da antiguidade e, no mais antigo dos relatos - a Torá -, o filósofo encontra o momento no qual Adão teria se expressado pela primeira vez num tipo de comunicação espiritual que não necessita de sinais sensíveis, conhecido como linguagem santa:

\footnotetext{
28 “342 Perciò questa Scienza, per uno de' suoi principali aspetti, dev'essere una teologia civile ragionata della provvedenza divina. La quale sembra aver mancato finora, perché i filosofi o l'hanno sconosciuta affatto, come gli stoici e gli epicurei, de' quali questi dicono che un concorso cieco d'atomi agita, quelli che una sorda catena di cagioni e d'effetti strascina le faccende degli uomini; o l'hanno considerata solamente sull'ordine delle naturali cose, onde «teologia naturale» essi chiamano la metafisica, nella quale contemplano questo attributo di Dio, e 'l confermano con l'ordine fisico[...]'.'La Scienza Nuova - Lib. I - Sez. I - Annotazioni alla tavola cronologica nelle quali si fa l'apparecchio delle materie - pág 150
} 
" 'Lógica' que deriva de logos e que antes e apropriadamente significou "fábula", que deu origem à palavra "favella" no italiano (que significa falar) - e a fábula para os gregos diz-se também mûthos, que para os latinos é " mutus “- tal lógica nos tempos iniciais, quando a linguagem era muda, nasceu mental...em que logos significa tanto "idéia" como "palavra"[...] e essa primeira forma de falar dos poetas teólogos não foi segundo a natureza das coisas (como deve ter sido a língua santa de Adão, a quem Deus concedeu a divina onomathesia, isto é, a imposição de nomes às coisas segundo a natureza de cada uma) mas foi um falar fantástico (fantasiado) por substâncias animadas, a maior parte delas imaginadas divinas". ${ }^{29}$

Para Vico, o ato de se comunicar teve um começo adâmico sobrenatural, no qual as coisas não precisavam ser imaginadas divinas; no momento seguinte, em que o homem tenta adivinhar, a comunicação é considerada natural, porque se baseia na formulação das idéias e começa com gestos - à maneira dos mudos, desenhos - na forma de ideogramas - e gemidos isto é, cantando ${ }^{30}$ :

"Os mudos se explicam por atos do corpo que possuem relações naturais com as idéias que querem significar.

Esta dignidade (axioma) ${ }^{31}$ é o principio dos hieróglifos e verificou-se que todas as nações os usaram para falar na sua primeira barbárie.

"Este é o princípio do falar natural que conjetural Platão no Crátilo em depois dele Giamblico, De mysteriis aegyptiorum ter-se falado no mundo." 32

\footnotetext{
29 "Logica vien detta dalla voce lógos, che prima e propiamente significò "favola", che si trasportò in italiano "favella" - e la favola da' greci si disse anco mûthos, onde vien a' latini "mutus", - la quale ne' tempi mutoli nacque mentale ..... onde lógos significa e "idea" e "parola"......perché cotal primo parlare, che fu de' poeti teologi, non fu un parlare secondo la natura di esse cose (quale dovett'esser la lingua santa ritruovata da Adamo, a cui Iddio concedette la divina onomathesia ovvero imposizione de' nomi alle cose secondo la natura di ciascheduna), ma fu un parlare fantastico per sostanze animate, la maggior parte immaginate divine.”- La Scienza nuova - Libro Secondo - Cap I - Lógica poética - pag 188

30 "230 Estes dois supostos axiomas (fazem suspeitar) que os autores das nações gentílicas, uma vez que foram levados a um estado ferino de selvagens mudos e privos de lógica, foram empurrados por violentas paixões e assim formaram as suas primeiras linguas cantando".- La Scienza nuova - Lib.I Sez II - Degli Elementi - pag 116
}

${ }^{31}$ Vico chama seus postulados de "degnità" ( dignidade ); para maior compreensão, usaremos axioma ou postulado para as "degnità" viquianas. 
As idéias e as imagens que nascem num momento infantil ( fanciullo $^{33}$ ) da humanidade tendem a ser mitificadas e é por meio da linguagem que o homem procura entender o mundo à sua volta: o fenômeno religioso aparece então como fator desencadeante de cultura. $\mathrm{Na}$ "metafísica della mente", o mito é responsável pelo eclodir de um tipo de sabedoria - a sapienza poetica - que acontece numa linguagem muta (muda) e se utiliza de gestos, imagens e gritos.

Vico apresenta um ser humano que, mesmo "bárbaro”, cultua, buscando entender os auspícios da divindade que o atemoriza; de acordo com sua teoria, o homem passa por diferentes etapas, não só no arco de sua própria vida como também no curso da história e em cada uma delas apresenta diferentes modos de expressão; numa primeira fase, através da fantasia criadora, a poesia - ou a linguagem comovida - se faz mediante gestos e sons representativos de emoções que anseiam revelar o mito. Numa segunda etapa, há um registro poético “fantástico" e finalmente, em tempos de reflexão, os registros serão feitos numa linguagem articulada.

"Os homens primeiro sentem sem se aperceber, depois se apercebem com espirito perturbado e comovido e finalmente refletem com mente pura." 34

As características potenciais do ser humano aparecem desde a fase adâmica e compõem aquilo que na teoria viquiana é chamado de "metafisica della mente": na mente dos seres humanos há um depósito de idéias e reside um universo de expressões que Vico define como "vocabolario mentale":

\footnotetext{
32 "225 I mutoli si spiegano per atti di corpo c'hanno naturali rapporti all'idee ch'essi vogliono significare . 226 Questa degnitá è 'l principio de' geroglifici, co' quali si truovano aver parlato tutte lê nazioni nella loro prima barbárie. 227 Quest'istessa è 'l principio del parlar naturale, che congetturò Platone nel Cratilo, e, dopo di lui, Giamblico, De mysteriis aegyptiorum, essersi una volta parlato nel mondo". - Vico faz referência a Cratilo; o filósofo grego pregava que não se deveria nem mesmo falar, devido à impossibilidade de se nominar as coisas: no momento em que o fazemos já são outra coisa e, na impossibilidade de nominá-las, é melhor mover apenas o dedo. (Metafisica, IV 5, 1010A). - La Scienza nuova - Lib. II - Cap I - Lógica poética - pag 188

33 “187 Esta dignidade filológico-filosofica prova que os homens do mundo infantil, por natureza, foram sublimes poetas.” - La Scienza nuova - Lib. I Sez.II - Degli elementi-pag107

34 “218 Gli uomini prima sentono senz'avvertire, dappoi avvertiscono con animo perturbato e commosso, finalmente riflettono con mente pura.” - La Scienza Nuova - Libro I Sez.II Degli elementi - pag114
} 
"É necessário que exista, na natureza das coisas humanas, uma língua mental, comum a todas as nações, a qual, de maneira uniforme, contenha a substância das coisas e atos da vida humana em sociedade, e a explique com diferentes modificações de acordo com os diversos aspectos das coisas; é assim que experimentamos serem verdadeiros os provérbios, que são máximas de sabedoria popular que utilizam aspectos significantes diferentes para expressar a mesma substância, e possuem o mesmo significado entendido por todas as nações, sejam elas antigas ou modernas." 35

Na concepção de Vico, o homem pré-histórico (ou o selvagem de tribos extintas ou ainda existentes) apresenta características comuns - no que se refere ao universo de idéias -, podendo manifestá-las, expressá-las e classificá-las de maneiras diferentes. O filósofo afirma ainda que todos os idiomas desenvolvem-se, apresentando estágios de evolução; ou seja, as falas vão se adaptando às fases vividas pelo homem e cada fase indica um estágio de apreensão e compreensão do mundo à sua volta. À medida que o espírito se torna menos perturbado, a criatividade, que é “proporcionalmente maior quanto menor for o raciocínio ${ }^{36}$, vai dando lugar à razão; nesse processo de desenvolvimento mental, a linguagem assume um papel de "facilitadora" e as fases evolutivas podem ser identificadas no modo como os homens se expressaram. Vico classifica, então, a passagem da linguagem emocionada para a articulada em três fases ou idades que acontecem no momento seguinte ao da linguagem santa; no relato da criação (registrado no livro de Gênesis da Torá), ao lado das noções e leis prescritas por Deus, o filósofo teria encontrado as tais características comuns ou os pressupostos universais e eternos, um dos quais aponta para a capacidade de comunicação, que acompanhará os homens nas fases divina, heróica e humana.

No início sem tempo, o relato mosaico sugere que o Criador teria estabelecido um padrão eterno de comportamento humano, que na metafísica viquiana parece como “ordens da

\footnotetext{
35“161 E' necessario che vi sia nella natura delle cose umane una lingua mentale comune a tutte le nazioni, la quale uniformemente intenda la sostanza delle cose agibili nell'umana vita socievole, e la spieghi con tante diverse modificazioni per quanti diversi aspetti possan aver esse cose; siccome lo sperimentiamo vero ne' proverbi, che sono massime di sapienza volgare, l'istesse in sostanza intese da tutte le nazioni antiche e moderne, quante elleno sono, per tanti diversi aspetti significate". - La Scienza Nuova - Libro I Sez.II Degli elementi- pag 101

36 "185 La fantasia tanto è più robusta quanto è più debole il raziocinio" - La Scienza Nuova - Libro I Sez.II Degli elementi - pag107
} 
providência”:

"Onde tal ciência deve ser uma demonstração, por assim dizer, de fato histórico da providência, porque deve ser uma história das ordens que ela (a providência), sem tomar discernimento e conselho e muitas vezes contra as proposições humanas, deu a todo o gênero humano e, mesmo que este mundo tenha sido criado em tempo e situações diferentes, as ordens que a providência colocou são universais e eternas." 37

Vico situa os “pressupostos eternos e universais", sugeridos na Torá, nos relatos mitológicos que deram origem à civilização ocidental; no relato bíblico estão expressos os pressupostos ou características intrínsecas do ser humano na figura de Adão e GV analisa de que forma o povo hebraico estabeleceu suas noções e leis a partir das prescrições divinas adâmicas. O livro do Gênesis expõe a criação do universo como um ato divino e a instituição das leis como uma decorrência de usos e costumes humanos. A Torá passa a ser, então, o documento oficial, no qual Vico localiza não só a divindade que dá origem e capacita o homem, como também a humanidade que é responsável pela criação e cristalização dos costumes que fazem a história.

“[...] este mundo civil foi certamente feito pelos homens, onde podem e devem ser encontrados os princípios dentro das modificações da nossa própria mente humana. Assim sendo, qualquer um que reflita sobre isso, ficará maravilhado como todos os filósofos estudaram seriamente para conseguir ter a ciência deste mundo natural, que por ter sido feito por Deus, só Ele possui a ciência." 38

Vico acredita que desde a gênese da humanidade exista um padrão, derivado de um

\footnotetext{
37 "342 Laonde cotale Scienza dee essere una dimostrazione, per così dire, di fatto istorico della provvedenza, perché dee essere una storia degli ordini che quella, senza verun umano scorgimento o consiglio, e sovente contro essi proponi-menti degli uomini, ha dato a questa gran città del gener umano, ché, quantunque questo mondo sia stato criato in tempo e particolare, però gli ordini ch'ella v'ha posto sono universali ed eterni".La scienza nuova - Lib. I Sez. IV -Del método - pág 150

38 "331[...] questo mondo civile egli certamente è stato fatto dagli uomini, onde se ne possono, perché se ne debbono, ritruovare i principi dentro le modificazioni della nostra medesima mente umana. Lo che, a chiunque vi rifletta, dee recar maraviglia come tutti i filosofi seriosamente si studiarono di conseguire la scienza di questo mondo naturale, del quale, perché Iddio egli il fece, esso solo ne ha la scienza"- La Scienza nuova - De’ principi - Lib. I Sez. III - pag 143
} 
fenômeno que engloba a religião, a linguagem e as leis, do qual não escapam Adão e o “bestione” pós-diluviano, pois ambos apresentam um esquema mental que os conduz a um relacionamento com a divindade. Tanto o homem adâmico como o bestione teriam passado por uma fase que Vico chama de "divina”, na qual a origem de uma civilização vincula-se à criação de mitos e deuses ${ }^{39}$; a fase seguinte desenvolve a anterior, enriquecendo-a de conceitos morais; por fim, o homem - na sua plena humanidade - explora suas capacidades e vive um momento mais elaborado.

"[...] os egípcios reduziam todo o tempo do mundo passado em três idades, que foram a idade dos deuses, idade dos heróis e idade dos homens. [...] e nelas falaram-se três linguas, que foram: a língua hieroglifica ou sagrada, a língua simbólica ou por semelhanças que é a heróica e a epistolar ou popular, expressa por sinais convencionados, para que se realizasse a comunicação necessária às necessidades da vida" 40

A fase divina do homem pós-diluviano é descrita na Ciência Nova como um período solitário e errante, impregnado de fábulas, mitos e poesia; esse prelúdio barbárico prepara as bases para a fase heróica, em que vemos a formação das cidades e das instituições; o terceiro e último período, progressista e intelectual, prepara um novo começo. Os “corsi e ricorsi” são a proposta viquiana para a continuidade da história, que recomeça sempre com as características da primeira fase divina, mas carrega consigo os germes do ciclo que se extinguiu. A cada recomeço, o homem apresenta um momento divinatório que parece querer resgatar a atmosfera poética perdida: nesse novo "corso" histórico, aparecem novos mitos que precisam ser revelados, dando origem a novos "poetas-teólogos" ${ }^{41}$, com as mesmas características do poeta teólogo adâmico; mas as novas fases são elevadas a um plano mais

\footnotetext{
${ }^{39}$ Toda vez que aparece uma fase divinatória no decurso da história, Vico a define como "barbárie ricorsa”, ou barbárie retomada.

40 " 173 Ci sono pur giunti due gran rottami dell'egiziache antichità, che si sono sopra osservati. De' quali uno è che gli egizi riducevano tutto il tempo del mondo scorso loro dinanzi a tre età, che furono : età degli dèi, età degli eroi ed età degli uomini. L'altro, che per tutte queste tre età si fussero parlate tre lingue, nell'ordine corrispondenti a dette tre età, che furono: la lingua geroglifica ovvero sagra, la lingua simbolica o per somiglianze, qual è l'eroica, e la pistolare o sia volgare degli uomini, per segni convenuti da comunicare le volgari bisogne della lor vita”.- La Scienza Nuova - Lib. I Sez II - Degli Elementi - pág 104

${ }^{41}$ Assunto do próximo item deste capítulo.
} 
alto porque se beneficiam das conquistas das fases anteriores.

Vico acredita num Deus Criador que teria idealizado um padrão humano, identificado em cada uma das idades metafísica ou divina, heróica e humana. O “espírito idealizador” que, na opinião do filósofo, concebe uma "história ideal eterna" ${ }^{42}$, pode ser verificado também na visão talmúdica de mundo: Vico e os rabinos encontram na Torá, escrita ou comentada, os fundamentos que imprimiram o caráter de todos os seres humanos de todas as épocas; nos pressupostos universais e eternos do ser humano e da natureza imperam as leis divinas, mas os usos e costumes geram as leis que governam a história.

Na visão talmúdica de mundo, cada palavra da Torá esconde um conceito que deriva de um princípio legislador que rege o universo; na visão viquiana, o mesmo princípio legislador dita o comportamento que leva o homem a se relacionar com a divindade inventada ou não - numa fase primitiva que Vico chama de “ferina”. A concepção talmúdica e a viquiana não se apóiam numa organização a partir do caos: as observações de caráter naturalístico não excluem a mente e as idéias dos seres humanos desde os tempos mais remotos, que só podem ser resgatados pelo estudo das mais antigas tradições registradas nas fábulas e lendas. Vico considera um momento barbárico diferente daquele que apresenta um possível ancestral simiesco: o bestione viquiano é um descendente de Noé, que por sua vez é um descendente de Adão. Tais proposições são colocadas na Ciência Nova, obedecendo a um critério de análise crítica das tradições literárias (verbal e escrita) antigas e clássicas e abrem espaço para uma suspeita, porém intrigante imagem do que teria sido o homem primitivo. E porque partem de pressupostos menos "exatos", revestem de importância os estudos lingüísticos e literários.

\footnotetext{
42 "245E este axioma com o precedente compõem uma parte da historia ideal eterna, sobre a qual correm em tempo todas as nações nos seus surgimentos, progressos, estados, decadências e fins." - La Scienza Nuova Lib. I Sez II - Degli Elementi - pág 119
} 


\section{2 O Dicionário Mental e os Poetas Teólogos}

Na Ciência Nova, a história civil dos hebreus e dos gentios se dá a partir de um fenômeno religioso, no qual o homem se relaciona com a divindade, mas a discussão filosófica e filológica, proposta por Vico, vai além das costumeiras especulações religiosas ${ }^{43}$ referentes às origens da humanidade: ao bater de frente com as teorias naturalistas de seus contemporâneos, o filósofo italiano estabelece uma linha de investigação em que a expressão - que dá forma às idéias embrionárias dos seres ferinos que povoavam a selva pós-diluviana assume um papel preponderante no processo civilizatório da humanidade e coloca em evidência um tipo de sabedoria que prepara o raciocínio e a reflexão. Sua empresa, no sentido de atribuir valor de documento aos relatos sagrados e antigos (até então considerados apenas como lendas) fornece um elemento novo e catalisador, que imprime um caráter inédito e indiscutível à fantasia criadora.

"O trabalho mais sublime da poesia é dar sentido e paixão às coisas insensatas." 44

A fantasia criadora que busca revelar o mito - o desconhecido - é, para Vico, decorrente do caráter sociável e religioso do homem. Vico acredita que antes mesmo de viver em comunidade, o homem - que quer se comunicar - capta a divindade; a religião é o primeiro princípio da sua ciência e os matrimônios solenes e o sepultamento dos mortos completam os três princípios sobre os quais o filósofo elabora um estudo filosófico e filológico.

\footnotetext{
${ }^{43}$ Os estudos sobre a origem da humanidade sempre deram margem a especulações, pois tudo o que se deseja investigar e teorizar a respeito de tempos longínquos tende a orientar-se segundo possíveis evidências que nem sempre podem beneficiar-se de documentos historiográficos ou epigráficos. Uma possível evidência passa a ser avaliada de acordo com propostas e sugestões que se apóiam em dois pólos divergentes: um de caráter evolucionista e outro de caráter criacionista. Contudo, embora ambos permaneçam até hoje no âmbito da teoria, as investigações a respeto das origens oferecem dados importantes para a análise do comportamento humano de todos os tempos, em todos os aspectos. É nesse contexto que a obra de Vico aparece, não como uma simples análise ou conjectura relativa à origem da humanidade, porque apresenta uma incontestável contribuição para o progresso do pensamento científico ao estabelecer o conceito de história e estética a partir da expressão humana fundamental que é a palavra.
}

44 “186 Il più sublime lavoro della poesia è alle cose insensate dare senso e passione”- La Scienza Nuova - Lib. I Sez II - Degli Elementi - pag 107 
"Concluímos tudo o que se expôs com relação ao estabelecimento dos princípios desta ciência, que são providencia divina, moderação das paixões com matrimônios e imortalidade das almas com as sepulturas; e os homens praticam isso como regra de vida social; e nisso concordam os legistas e os estudiosos, isto é, que esses são os confins da razão humana e todos que acham que podem ficar fora disso, correm o risco de não serem considerados humanos." 45

As tradições históricas se desenvolvem baseadas nesses três princípios, provando que o caráter social do homem é uma constante e se faz por meio do uso da linguagem. No relato bíblico, o livro de Gênesis apresenta o relacionamento entre Adão e Deus:

\section{"[...] ouviram a voz do Senhor Deus, que andava no jardim pela viração do dia" 46}

O texto sugere um tipo de relacionamento ideal com a divindade e coloca o momento em que é dado a Adão o dom da onomathesia:

"Havendo pois o Senhor Deus formado da terra e todo o animal do campo, e toda a ave dos céus, os trouxe a Adão, para este ver como lhes chamaria; e tudo o que Adão chamou a toda a alma vivente, isso foi o seu nome." 47

O poeta ainda não nascera, pois não existia nada a ser revelado; o poeta só nasce quando existe algo a ser captado e nasce, portanto, quando morre a linguagem pura que nomeava as coisas segundo a natureza de cada uma; "o trabalho da poesia de dar sentido e paixão às coisas insensatas" viria num momento seguinte.

\footnotetext{
45 “360 Conchiudiamo tutto ciò che generalmente si è divisato d'intorno allo stabilimento de' princìpi di questa Scienza: che, poiché i di lei principi sono provvedenza divina, moderazione di passioni co' matrimoni e immortalità dell'anime umane con le seppolture; e 'I criterio che usa è che ciò che si sente giusto da tutti o la maggior par te degli uomini debba essere la regola della vita socievole (ne' quali principi e criterio conviene la sapienza volgare di tutti i legislatori e la sapienza riposta degli più riputati filosofi): questi deon esser i confini dell'umana ragione. E chiunque se ne voglia trar fuori, egli veda di non trarsi fuori da tutta l'umanità - La Scienza nuova - .Lib.I Sez.IV - Del Método - pag 157

${ }^{46}$ Gen 3:8 - Bíblia Sagrada

${ }^{47}$ Gen 2:19 - Bíblia Sagrada
} 
"porque tal primeiro falar, que foi o dos poetas teólogos, não foi um falar segundo a natureza dessas coisas (como deve ter sido a língua sagrada criada por Adão, a quem Deus concedeu a divina onomathesia, ou seja, a imposição dos nomes às coisas, segundo a natureza de cada uma)" 48

A idéia de uma linguagem adâmica foi compartilhada pelo jesuíta Ludovico Bertoni ${ }^{49}$ que com a obra publicada em 1603, a "Arte de lengua Aymara", descreve "uma língua ainda falada hoje na região limitrofe entre a Bolívia e o Peru; trata-se de um idioma de imensa flexibilidade, capaz de uma incrível vitalidade para se criar neologismos, particularmente adequado a expressar abstrações, a ponto de levantar suspeitas de que se trate do efeito de um artifício”. Emeterio Villamil de Rada ${ }^{50}$, já no séc. IX, fala de uma língua adâmica, “expressão daquele parentesco natural entre as palavras e as coisas", em que existiria "uma idéia anterior à formação da língua", fundamentada nas "idéias necessárias e imutáveis”, a que Vico chamaria de pensamento universal que só pode ser transmitido por caracteres poéticos.

“[...] as crianças, com idéias e nomes de homens, mulheres e coisas que olham pela primeira vez, aprendem e chamam todos os homens, mulheres, coisas que aparecem em seguida, com nomes que têm com as primeiras alguma semelhança ou relação - e esta é a primeira fonte dos caracteres poéticos, com os quais naturalmente pensaram os primeiros povos." 51

\footnotetext{
${ }^{48}$ La Scienza nuova - Lib.II Sez.II. Cap I - Logica Poetica - pág 189

49 “Teorie contemporanee della traduzione” - Siri Nergaard, 1995 - (Nossa tradução). Ludovico Bertoni: "Vocabulario de la lengua aimara" - Teubner, Leipzig,1879 .

${ }^{50}$ Villamil de Rada - em 1860 - pode ter se baseado na obra do linguista alemao Schlegel (quem, em 1808, publicou seu "Uber die Sprache und Weisheit der Inder" ("Sobre a linguagem e sabedoria hindu"), um livro que revolucionou as teorias linguisticas. Karl Wilhelm Friedrich von Schlegel ( 1772 - 1829.Linguista, crítico literario, filósofo, especializado em língua espanhola e poeta alemao, um dos fundadores do Romantismo, irmão também do filólogo August Wilhelm Schlegel. Valendo-se das observações de Sir William Jones (1746-1794) sobre as semelhanças entre o sanscrito e as outras línguas - latim, grego e persa - Schlegel afirmou que a India era o berço da civilização ocidental. - Disponível em: www.aymara.org/biblio/igr/igr1.html. Acesso out/2006.

51 "412[...] i fanciulli con l'idee e nomi d'uomini, femmine, cose, c'hanno la prima volta vedute, apprendono ed appellano tutti gli uomini, femmine, cose appresso, c'hanno con le prime alcuna simiglianza o rapporto", e che questo era il naturale gran fonte de' caratteri poetici, co' quali naturalmente pensarono e parlarono i primi popoli”. - La scienza Nuova - lib II.sez II. Ap. I - Logica poética - pág 196
} 
Essa idéia anterior à formação da língua é outra versão para aquilo que Vico chama de dizionário mentale. Por meio de complicadas tramas de gramática histórica e de filologia, Vico explica a origem de certos termos que conhecemos e consolidamos hoje e que teriam partido dos "grunhidos" gerados pelas emoções do homem pós-diluviano na tentativa de conhecer o mundo à sua volta. Vico justifica suas teorias estabelecendo uma "lógica poética", que será o fundamento teórico-científico para a elaboração de seu pensamento estéticofilosófico.

GV apresenta o "dizionario mentale” como um depósito de idéias no qual reside a língua perfeita. Umberto $\mathrm{Eco}^{52}$, nas suas "Reflexões teórico-práticas sobre a tradução", nos revela o segredo para uma análise de textos desta natureza : "encontrar não digo a intenção do autor, mas a intenção do texto, aquilo que o texto diz com relação à língua com a qual foi expresso e com relação ao contexto cultural no qual nasceu." Eco intuiu uma "lingua perfetta":

“Talvez exista um senso que vive além da obra. E se existe - e de alguma maneira o tradutor deverá presumi-lo - teria de ser expresso numa terceira linguagem que constitui o parâmetro com o qual se adequam ou tentam se adequar tanto a lingua de partida como a lingua de chegada. Essa terceria língua pode ser equiparada à lingua perfeita da mente, isto é, a lingua Pura, uma lingua que ninguém jamais falou ou talvez somente Deus e os Anjos a tenham falado, mas que pode ser atingível no esforço da tradução." 53

O esforço de Vico e dos tradutores pode ser tomado como uma tentativa de decifrar a essência da mensagem que, na verdade, é o próprio dicionário mental viquiano. No mesmo texto, Eco coloca o parecer de Walter Benjamim ${ }^{54}$ :

“ Sendo impossivel reproduzir na língua de chegada os significados da língua de

\footnotetext{
${ }^{52}$ Umberto Eco ( 1932- ) Doutor em semiótica, a estética medieval, a comunicação de massa, lingüística e filosofia.

53 "Teorie contemporanee della traduzione” - Siri Nergaard,1995 - (Nossa tradução).

${ }^{54}$ Walter Benjamin (Berlim 1892 -1940). Filósofo crítico das técnicas de reprodução em massa da obra de arte.
} 
partida, é necessário confiar no sentido de convergência entre todas as línguas, enquanto em cada uma delas - tomada como um todo - entende-se uma única coisa que todavia não é acessivel a nenhuma delas em particular, mas só na totalidade da intenção de todas, que se complementam: a lingua Pura. Mas essa "reine Sprache" ou essência da linguagem não é uma língua. Se considerarmos as fontes cabalísticas do pensamento de Benjamim, podemos captar aquilo que se conhece como línguas santas - algo semelhante ao uso, muito cabivel, das línguas pentecostais e da Língua dos pássaros - de que devaneava Cyrano di Bergerac; a tradução ou o desejo de tradução não é possivel sem essa correspondência com o pensamento de Deus.. " 55

Portanto, a língua pura, a língua adâmica e o "vocabolario mentale" de Vico, seriam a fonte das línguas articuladas. De tal vocabulário (ou dizionario), os diversos povos e tribos teriam extraído, de maneira mais ou menos semelhante, cá e acolá, em diferentes tempos históricos, os conceitos de religião, filosofia, economia, direito etc. que fizeram e fazem a história. Dessa mesma fonte Moisés também teria bebido para escrever os textos da Torá. “As verdades histórico-sociológicas, psico-antropológicas, sacro-filosóficas da Torá são captadas por Moisés, que aparece como o compilador dos resíduos comunicados pelas gerações anteriores; nas atividades e no repertório de Adão - e assim para os” bestioni” pós-diluvianos - estavam implícitos os conceitos universais que geram cultura. Tais conceitos são fruto do esforço criativo do homem que quer comunicar o conteúdo do dicionário mental.

O primeiro homem, ao longo do processo de diluição da linguagem santa - uma forma pura e ideal de comunicação - teria iniciado um momento no qual a comunicação se dá por imagens. Àquilo que conduz Adão a exercitar sua capacidade expressiva, o filósofo chama de sabedoria poética, de onde deriva a "lógica poética "que dá forma ao mundo visível e intelectual da humanidade. ${ }^{56}$

Tanto a fase adâmica como a diluviana referem-se a um período atemporal que não pode se beneficiar de indícios ou documentos epigráficos; contudo, a tradição judaica repassa a idéia de que Noé e seu filho Sem teriam perpetuado os ensinamentos passados pelo poeta-

\footnotetext{
55 “Teorie contemporanee della traduzione” - Siri Nergaard,1995 - “La lingua perfetta” - pag 134

${ }^{56}$ No livro II - Cap I "Della sapienza generalmente”, Vico define o homem como mente e alma, isto é, intelecto e vontade; com a "poética", isto é, com a capacidade de se expressar, o homem consegue pensar e definir o mundo. O livro II, como um todo, mostra como o homem foi definindo as diferentes áreas da vida "falando".
} 
teólogo Adão. Os hebreus aparecem como os autores de uma civilização baseada nos registros das tradições que deram origem ao relato mosaico. Flavio Josefo, escritor judeu do séc. I, diz no seu livro "A história dos hebreus":

"Seria demasiado longo falar de todos os filhos de Adão; contentar-me-ei em dizer alguma coisa de um deles, de nome Sete. Foi educado junto de seu pai e deu-se com afeto à virtude [...]. Deve-se ao seu espírito e ao seu trabalho a ciência dos astros. Como eles tinham sabido de Adão que o mundo pereceria pela água e pelo fogo, o medo que tiveram de que essa ciência se perdesse - antes que os homens a aprendesse - levou-os a construir duas colunas, uma de tijolos outra de pedras, sobre as quais gravaram os conhecimentos que possuiam, a fim de que, se acontecesse que um dilúvio destruísse a coluna de tijolos ficasse a de pedra, para conservar a posteridade a memória daquilo que eles tinham escrito. Sua previdência deu bom resultado e afirma-se que essa coluna de pedras pode ser vista ainda hoje na Síria." 57

Josefo escreveu, tomando por base a Torá e provavelmente tudo o que sempre ouviu nas sinagogas, acedendo, portanto, à metafísica della mente de seus antepassados. Vico registra um período atemporal, tomando por base a Torá e outros livros antigos, inferindo a existência de uma metafísica da mente humana que contém as especificações que redundarão num comportamento padrão, que é notadamente religioso, numa primeira fase civilizatória. Na Torá estão registradas as idéias do povo hebreu com relação ao seu Deus, que Vico coloca como “Ottimo Massimo" 58 e nas outras tradições, os registros apontam para deuses inventados; mas o começo divinatório é o mesmo.

No começo, que Vico classifica como divinatório, há sempre a presença de uma divindade que o homem almeja conhecer; na Torá, a ordem divina de não comer da árvore do conhecimento do bem e do mal ilustra uma forma de relacionamento entre a criatura e seu criador e os primeiros conceitos jurídicos são estabelecidos a partir de uma ordem, um delito e uma sentença:

\footnotetext{
${ }^{57}$ JOSEFO, Flavio - "História dos hebreus” - pág. 16

${ }^{58}$ A expressão viquiana “Ottimo Massimo” significa “o mais forte, o maior”, embora Vico se refira ao Deus dos hebreus como "verdadeiro".
} 
"De toda árvore do jardim comerás livremente, mas da árvore do conhecimento do bem e do mal, dela não comerás; porque no dia em que dela comeres, certamente morrerás." 59

No texto, Adão escolhe conhecer o bem e o mal, exercitando seu livre-arbítrio - um pressuposto eterno e universal - sem a interferência divina e a transgressão o condiciona a viver debaixo da sentença de morte. Porém, mesmo vivendo numa contingência de morte física, a salvação (para a morte espiritual) acontecerá mediante um novo relacionamento que inaugura a cosmogonia judaico-cristã e prevê uma dramática tentativa de conhecer o bem e o mal "interpretando" os auspícios divinos, o que não aconteceria mais por meio da vera narratio $^{60}$. A comunicação entre a criatura e o criador, inicialmente íntima e espiritual, agora se servirá de códigos e sinais, isto é, será feita por caracteres poéticos (sinais que os estudiosos reconhecem analisando os substratos da Torá, isto é, as tradições Elohista e Jawista - de que falaremos no próximo capítulo). A descendência de Adão pôde desfrutar da condição santa de viver debaixo da graça, que se traduz pela crença e obediência ao Deus verdadeiro, descrito na Torá. Na fase pós-diluviana, o fenômeno da fala - que acontece como uma explosão poética do homem primitivo diante do deus de quem quer entender os auspícios - é explicado por Vico por meio do vocábulo “ius”.

"Com o nascimento dos caracteres poéticos e das línguas, nasceu a gius, ou dito ious para os latinos, e para os gregos diaión - que mais adiante poderá ser explicado como "celeste", ou dito de Diós;... Porque universalmente, por todas as nações gentílicas o céu foi observado da mesma maneira, ou seja, com o aspecto de Jove de quem se recebem as leis e comandos, tidos como auspícios; o que demonstra que todas as nações nasceram sobre a persuasão da divina providência." 61

\footnotetext{
${ }^{59}$ Genesis 2: 16-17 - Bíblia Sagrada

60 "e mûthos chegou-nos como "vera narratio", ou seja "falar verdadeiro", que foi o "falar natural" que antes Platão e depois Giamblico disseram que ter-se falado no passado". Nossa tradução - La Scienza nuova - Lib.II - Sez. II Cap I - Lógica poética - pag 188

61 "473 Con tal primo nascere de' caratteri e delle lingue nacque il gius, detto "ious" da' latini, e dagli antichi greci diaión - che noi sopra spiegammo "celeste", detto da Diós; onde a' latini vennero "sub dio" egualmente e "sub Iove" per dir "a ciel aperto" - e, come dice Platone nel Cratilo, che poi per leggiadria di favella fu detto dikaion. Perché universalmente da tutte le nazioni gentili fu osservato il cielo con l'aspetto di Giove, per
} 
A ius, segundo Vico, surge do deslumbramento do homem, disperso pela selva verdejante e exuberante em decorrência da umidade provocada pela inundação catastrófica: ao deparar-se com o raio - um fenômeno até então desconhecido - esse bárbaro e solitário ser humano se expressa de maneira instintiva, emitindo grunhidos e, também de maneira instintiva, cria um mito, a partir de um fenômeno da natureza. De acordo com a teoria viquiana, o monossílabo ius seria a exclamação emocionada, e, portanto poética, do homem perante o raio; ius personifica Júpiter, presente na mitologia de diferentes povos e é, de acordo com Vico, a criação de um poeta-teólogo “ferino” que se expressa na língua latina.

Exclamações semelhantes teriam dado origem a outras línguas e outros mitos; o “germe desencadeador e criador do mito”, porém, é universal, pois provém da psique humana. A uma primeira aproximação deslumbrada com o mito criado segue-se a tentativa, instintiva, de captar os auspícios divinos, de onde deriva a manifestação jurídica primitiva que processa alguns conceitos normativos. As sociedades se formam livremente, no decorrer do desenvolvimento das faculdades e manifestações do homem; o mundo social, porém, só existe por obra e vontade de uma Inteligência Superior que Vico chama de Dio Ottimo Massimo ou Provvedenza, a qual não força os homens com leis, mas os governa por meio das leis geradas a partir dos seus usos e costumes. Assim como a religião e a poesia, o direito não é resultado de um processo civilizatório: é uma manifestação primária da qual deriva a civilização.

E, na distinção que Vico faz entre Direito Talmúdico (presente nas leis da Tora) e Direito natural das gentes (que dará origem ao Direito Romano), está implícita a qualidade do deus do qual derivam os auspícios:

"Este mesmo postulado estabelece a diferença entre direto natural dos hebreus e direito natural das gentes e direito natural dos filósofos. Porque as gentes (de gentios) tiveram somente a ajuda ordinária da providência; os hebreus tiveram também ajudas extraordinárias do Deus verdadeiro e por isso, o mundo das nações era dividido entre hebreus e gentes." 62

\footnotetext{
riceverne le leggi ne' di lui divini avvisi o comandi, che credevan esser gli auspici; lo che dimostra tutte le nazioni esser nate sulla persuasione della provvedenza divina" - La Scienza Nuova - Lib II Sez.II Cap VI Logica poetica - pag 234

62 "313 Questa stessa stabilisce la differenza del diritto natural degli ebrei, del diritto natural delle genti e diritto natural de' filosofi. Perché le genti n'ebbero i soli ordinari aiuti dalla provvedenza; gli ebrei n'ebbero anco aiuti estraordinari dal vero Dio, per lo che tutto, il mondo delle nazioni era da essi diviso tra ebrei e genti;"'- La Scienza Nuova - Lib.I Sez.II - Degli Elementi - pag 137
} 
De acordo com Vico as religiões que advêm do judaísmo podem usufruir da ajuda extraordinária de Deus, desde que se atenham às prescrições divinas: a figura de Noé como precursor da tradição do Deus verdadeiro só pode ser entendida a partir de um começo adâmico no qual o conhecimento do bem e do mal ${ }^{63}$ e a noção de transgressão já teriam sido, de alguma maneira, transmitidos. Após a transgressão ou desobediência (o pecado original), Adão também teria passado por uma fase na qual a poesia se presta a desvendar o mito e, por meio da poesia, os homens adâmicos teriam deixado suas marcas e sinais. É pela poesia que as emoções encontram o canal para descobrir o desconhecido; à medida que aprende a falar, o homem vai, aos poucos, articulando as idéias que o ajudarão - num momento seguinte - a refletir com mente pura.

\section{3 A poesia e a religião: a teoria da graça e o sentimento do trágico}

"E aconteceu ao cabo de dia que Caim trouxe dos frutos da terra uma oferta ao Senhor. E Abel também trouxe dos primogênitos das suas ovelhas e da sua gordura." 64

O relato bíblico apresenta os filhos de Adão cultuando e aspirando comunicar-se com a divindade; seus descendentes desenvolvem suas falas poéticas - ferramentas para revelar o mito num ambiente não mais paradisíaco. Os filhos de Adão e Eva teriam aprendido com seus pais a oferecer sacrifícios e puderam exercitar o livre-arbítrio, escolhendo entre o bem e o mal. Com a morte de Abel, Set, o terceiro filho de Adão e Eva, gera Enos e, com ele, inicia-se um tempo civilizatório pleno, no qual a atitude de cultuar é evidente por um de seus aspectos lingüísticos principais: a invocação.

"então se começou a invocar o Senhor" 65

\footnotetext{
63 “ Os poetas teólogos, ou "sábios que se entendiam do falar dos deuses advindo dos auspícios de Jove, foram chamados de divinos no sentido de adivinhadores ou aqueles que podiam pré-dizer ou profetizar. Dai Omero definir a "musa", como a ciencia do conhecimento do bem e do mal e sobre essa ciência Deus colocou a proibição a Adão. “- La Scienza Nuova - Lib.II. Cap.I - Della Sapienza generalmente - pag 163

${ }^{64}$ Gênesis 4: 3,4 - Bíblia Sagrada

${ }^{65}$ Gênesis 4:26 - Bíblia Sagrada
} 
Os descendentes de Adão iniciam uma civilização baseada nas prescrições divinas: a verdadeira religião e o culto ao Deus verdadeiro, segundo Vico, são uma herança adâmica que subsiste após o dilúvio através de Sem. O recomeço a partir do dilúvio teria determinado dois caminhos distintos para a humanidade: a história do povo hebreu e a história dos outros povos. De acordo com a teoria viquiana, os hebreus, descendentes de Sem, possuem um início e uma história ligados à verdadeira religião. Os gentios - descendentes de Cam e Jafet, filhos ímpios de Noé - instituem novas religiões e uma continuidade histórica em que os mitos são desvendados num ambiente em que o caso e a fatalidade predominam.

Vico considera os judeus salvos das peripécias do destino, pois podem usufruir da graça divina, na medida em que obedecem e plasmam suas vidas dentro de uma sociedade teocrática; por outro lado, os descendentes de Cam e Jafet teriam apostado em suas próprias convicções, adotando um comportamento considerado idólatra e humanista, ao qual se deve a formação da cultura ocidental, alimentada por um sentimento do trágico que pode ser entendido como uma visão de mundo fora da graça.

George Steiner ${ }^{66}$ afirma que "todos os homens têm consciência da tragédia da vida" e parece concordar com Vico quando diz que a tragédia é "alheia ao sentido judaico do mundo". Por meio da redenção, da compensação e da justiça divina, o judeu acredita que a ordem do universo e da condição humana é acessível à razão e se traduz num comportamento de obediência e temor a Deus. No sentido judaico da vida, não há nenhum tipo de germe ou herança que pressuponha a fatalidade, o destino e a tragédia; os sentimentos, as emoções e os fatos estão subordinados a Deus. Na gentilidade, de onde deriva a cultura ocidental, os fatos estão sujeitos aos sentimentos e às emoções, gerando um desequilíbrio no qual se instala a tragédia. Vico toma o conceito de pecado ou transgressão e de graça divina do relato de Gênesis e empreende um caminho semelhante àquele percorrido pelos que condenam a hybris $^{67}$; porém vincula a linguagem e o decorrente processo civilizatório à transgressão cometida contra o Deus verdadeiro dos hebreus.

\footnotetext{
${ }^{66}$ George Steiner - “A morte da tragédia” - pág 9

67 “Hybris, conhecida como o sentimento de orgulho desmedido que leva os heróis da tragédia a perpetrar uma violação à ordem estabelecida, através de uma ação que se constitui como um desafio aos poderes e ordem divinos. Incorre num erro, hamartia, que provoca a némesis, indignação divina que se consubstancia numa
} 
Segundo o texto do Gênesis $2^{68}$, Adão transgride ao querer conhecer o bem e o mal sem a interferência divina e é exatamente a tendência intelectual que insiste em rejeitar a fonte de vida (o próprio Deus) que gera a morte; inaugura-se então a história. Num tempo eterno,ou num início sem tempo e sem morte, a linguagem é santa; na cronologia do tempo, a linguagem se servirá de códigos e sinais. A tradição judaica sustenta o comando que proíbe a adivinhação, fazendo com que a comunicação com Deus seja o mais próximo possível daquela santa dos inícios.

Na fase adâmica, encontramos um momento “sem história”, no qual a fala ideal e a eternidade não abrem espaço para a poesia e a história. O pai comum - Adão - não pertence a nenhuma idade viquiana “ainda” e só funda a primeira fase “divinatória” após a queda: com ela, entra em cena a graça e o tempo cronológico que gera a história ideal eterna. Adão, assim como o "bestione” da idade ferina, passa também a captar os auspícios divinos numa língua nascente e profana, que Vico definiria como pré-poética: a poesia é a ferramenta com a qual o homem expressará suas emoções e angústias num mundo hostil não paradisíaco.

O livro do Gênesis transcreve a trágica herança poética de Adão, que teria sido transmitida oralmente aos primeiros homens que povoaram a terra; e as tradições geradas até a compilação do relato mosaico serviram-se de poetas-teólogos desconhecidos até que, em Moisés, identificamos um poeta-teólogo que conhece o nome da divindade - o "Eu sou" ${ }^{69}$, por meio de um fenômeno conhecido como "sarça ardente”. Moisés recolhe, numa linguagem articulada e certamente imbuído de conhecimentos re-elaborados, os resíduos da mensagem transmitida de geração em geração e reúne, no Pentateuco, aquilo que pode ser considerada a cartilha da tradição judaico-cristã. Os rabinos acedem ao texto compilado da Torá comportando-se como os tradutores de textos sagrados que pretendem resgatar a história original, buscando os elementos que deram corpo ao dicionário mental dos homens que geraram as tradições e lendas mais antigas. Vico adota um comportamento semelhante ao apresentar a mitologia grega como o resultado escrito da história do começo gentílico, em que

punição ou desgraça que sobre eles se abate”. - Disponível em: faroldasletras.no.sapo.pt/glossario.htm.Acesso em mar 2006

68 “De toda árvore do jardim comerás livremente, mas da árvore do conhecimento do bem e do mal, dela não comerás; porque no dia em que dela comeres, certamente morrerás”. - Genesis 2: 16-17 -Bíblia Sagrada

69 “Eu sou” é uma versão para o tetragrama YWTH, impronunciável para os judeus. - Êxodo 3 - Bíblia Sagrada. 
o modelo mitológico grego faz parte de um proceder universal que teria começado com os hebreus.

O conjunto das tradições é analisado na Ciência Nova como o resultado escrito das tradições orais dos povos antigos, em que Moisés e Homero são ”caracteres poéticos”- figuras que podem não ter existido e que aparecem como autores de uma história residual. Do mesmo modo, as lendas e fábulas dos gentios, teriam sido transmitidas e transcritas seguindo o modelo judaico, utilizando a poesia como ferramenta para desvendar o mito. As sucessivas descendências, que prosseguiram por meio de um peregrinar ferino desviado da graça, obedecem aos seus próprios sentimentos e paixões e exercitam a ”poiesy “70 de múltiplas formas, também escritas. A essas descendências devemos a existência de registros e documentos - imagens palpáveis e escritos decodificáveis que compõem o acervo históricoartístico da humanidade. Recorremos a eles para aceder , de maneira um pouco mais segura, ao universo de idéias do homem. Vico pretendeu resgatar o passado sem registros, apoiandose nas imagens da Torá e em outros livros sagrados e antigos; decifrando a história embutida no” falar fantástico” (fantasioso), os mitos vão sendo revelados e a história antiga toma forma.

Para o filósofo, a poesia que traduz as imagens e conceitos do homem que vive numa fase divinatória, revela a capacidade de um "bestione” que cria antes mesmo de pensar: o universo de idéias e sensações que constituem o dicionário mental faz parte da essência humana e opera antes do cógito ${ }^{71}$. Vico considera o homem dotado da capacidade de pensar “falando" e coloca a linguagem no centro de suas especulações de caráter metafísico, que oferecem argumentos diferentes daqueles propostos pela teoria da evolução: a existência de uma mente legisladora e de uma metafísica della mente define o caráter criacionista da teoria viquiana sobre o início das civilizações, em que sentimentos, falas e leis constituem a matéria prima que dá forma à história da humanidade; com eles, Vico e os rabinos fazem ciência.

\footnotetext{
${ }^{70}$ Vico adota o conceito aristotélico: “[...] os primeiros homens das nações gentílicas, como crianças do gênero humano[...] .de sua idéias criavam as coisas [...] fingindo, criavam-nas, razão pela qual foram chamados poetas, que o mesmo em grego soa como criadores" - A Ciência Nova -trad. Marco Lucchesi - A metafísica poética pag. 154.

${ }^{71}$ Enquanto Descartes coloca a existência humana no ato de cogitar, Vico apresenta a fantasia criadora como a primeira forma de sabedoria com a qual o homem aprende a refletir.
} 


\section{CAPÍTULO II}

\section{Os pressupostos viquianos e a literatura judaica: o modelo judaico de aculturação}

\section{1 Um princípio civilizatório comum identificado na mitologia dos povos}

Para Vico, cada povo, guiado por um instinto natural, cria seus próprios deuses e fábulas, em tempos e lugares diferentes, poesia e religião são manifestações de uma fase primitiva da humanidade. Para raciocinar o mundo à sua volta, o homem advinha falando e a desenvolve com a voz a capacidade de “divinare", isto é, a capacidade de "entender o que está escondido aos homens, o porvir, ou aquilo que está escondido dentro de sua própria consciência". ${ }^{72}$ No "incominciamento" ${ }^{73}$, o homem vive um momento divino, no qual a expressão humana se faz pela poesia.

"Primeiro que, sobre as coisas que meditaremos, convêm às nossas mitologias, não forçadas ou distorcidas, mas diretas, fáceis e naturais, e se demonstrará que são historias civis dos primeiros povos que, como se pode verificar por toda a parte, foram poetas.", 74

Considerar a mitologia como a real história civil dos primeiros povos é mérito de

\footnotetext{
72 "[...] E também sobre a economia das coisas civis deviam raciocinar com toda a propriedade da voz, com a qual a providência foi chamada "divindade", que provém de "divinari, "advinhar", isto é entender aquilo que está escondido aos homens, que é o porvir, o escondido dos homens, que é a consciência " - La scienza nuova Lib.I.Sez IV - Del Método - pag 151

${ }^{73}$ Com a palavra "incominciamento" Vico se refere ao começo da humanidade e das civilizações Vico. O vocábulo não traz referência direta às diversas teorias a respeito da formação do universo e do aparecimento do homem na terra, embora Vico, católico convicto, compartilhe da teoria da criação. Do mesmo modo, Vico relaciona o vocábulo divino com divinare - algo muito mais próximo da capacidade de falar, sem alusão a conceitos místicos ou religiosos.

74 “352 Primo, che sulle cose le quali si meditano vi convengono le nostre mitologie, non isforzate e contorte, ma diritte, facili e naturali, che si vedranno essere istorie civili de' primi popoli, i quali si truovano dappertutto essere stati naturalmente poeti." - La Scienza Nuova - Lib.I Sez. IV- Del método - pag. 156
} 
Vico. Os acontecimentos reais do passado longínquo foram classificados como mitologias e lendas devido às convenções e parâmetros criados pelas sociedades que refletem “com mente pura”. As imagens, tidas como fábulas, foram retratadas poeticamente numa linguagem que usa caracteres próprios e nascentes. A atitude de Vico, ao analisar o mito e a história que o cerca, pode ser comparada à dos tradutores que, procurando abster-se de visões etnocêntricas, estabelecem o vínculo real existente entre a linguagem e a cultura, mantendo-se vigilantes para não se comportarem como os doutos de sabedoria re-elaborada. ${ }^{75}$

Vico considera a dinâmica da linguagem no tempo (a filologia), procurando visualizar a prática civil dos povos antigos e constata que a religião, os matrimônios solenes e o sepultamento dos mortos são práticas comuns, tanto em povos bárbaros como desenvolvidos; analisando a mitologia dos povos, Vico propõe que, na mente do ser humano, tenha sido ditado um senso comum, isto é, algo de “instintivo e consensual”:

"Observamos que todas as nações, sejam bárbaras ou humanas (desenvolvidas), por longos periodos de tempo e distantes entre si, fundadas isoladamente, adotam estes três costumes: todas têm alguma religião, todas contraem matrimônios solenes e todas sepultam seus mortos; entre as nações, as mais selvagens ou "cruas", celebram com solenidades até mais ricas e detalhadas as religiões, os matrimônios e as sepulturas. Portanto, o postulado "idéias uniformes nascidas entre povos desconhecidos entre si, devem ter um principio comum de verdade" deve ter sido ditado a todas (as nações); dessas três coisas começou toda a humanidade e acabam sendo preservadas e mantidas por todas como coisas santas, a fim de que o mundo não se torne selvagem de novo. Sendo assim, destacamos os três costumes eternos e universais como sendo os três principios desta Ciência." ${ }^{76}$

\footnotetext{
75 “363 E por todo este livro se mostrará que muito cedo os poetas sentiram e manifestaram sua sabedoria popular para que depois entendessem de fato os filósofos com sua sabedoria re-elaborada ( riposta); e pode-se dizer que os primeiros foram o senso e os segundos o intelecto do gênero humano.” - La Scienza Nuova - Lib. II -Della sapienza poetica - Prolegomeni. - pág 162
}

76 “333 Osserviamo tutte le nazioni cosi barbare come umane, quantunque, per immensi spazi di luoghi e tempi tra loro lontane, divisamente fondate, custodire questi tre umani costumi: che tutte hanno qualche religione, tutte contraggono matrimoni solenni, tutte seppelliscono i loro morti; né tra nazioni, quantunque selvagge e crude, si celebrano azioni umane con più ricercate cerimonie e più consagrate solennità che religioni, matrimoni e seppolture. Ché, per la degnità che «idee uniformi nate tra popoli sconosciuti tra loro, debbon aver un principio comune di vero», dee essere stato dettato a tutte: che da queste tre cose incominciò appo tutte 
Vico apresenta as características intrínsecas (fisiológicas e metafísicas) do ser humano como pressupostos eternos, uma espécie de “instinto natural” responsável pelo estabelecimento de ulteriores princípios eternos que ditam os usos e costumes. Pressupostos como o livre arbitrio, que caminha lado a lado com o bom senso, operam na mente coletiva dos povos e definem as escolhas que, por sua vez, definem os usos e costumes dos povos. Embora variem na forma - apresentando linguagens e rituais específicos - os princípios que geram as civilizações derivam de características comuns. À medida que práticas recorrentes vão sendo verificadas nas lendas e relatos dos povos da antiguidade, Vico emite seus postulados relativos aos pressupostos eternos e sua pesquisa, obviamente, começa pela Bíblia, já que os judeus registraram suas memórias desde o princípio.

No caso da memória dos latinos, por exemplo, o resgate de fatos perdidos (ou mal interpretados ao longo do tempo) praticamente dependeu do trabalho de Vico. Os judeus mantiveram e mantêm suas memórias e a prova disso é a existência da Torá e o incansável trabalho literário gerado a partir dela. A Ciência Nova surge do trabalho de Vico como a compilação "rabínica” daquilo que fora um amontoado de lendas: em apenas vinte anos, o filósofo italiano empreende um esforço que aproxima seu trabalho acadêmico ao trabalho intelectual e espiritual dos rabinos. Partindo da Torá, Vico analisa e estuda a relação do homem adâmico com Deus e a formação da nação judaica em função da conservação de suas tradições orais e escritas e admite a existência de um modelo de aculturação judaico que será constatado em outros povos; as atitudes humanas confirmam os pressupostos eternos, que brotam da metafísica della mente humana, responsável também pela construção do vocabulario mental. É nessa ótica que o mito funciona como um "gabarito", com o qual o filósofo napolitano funda um método de investigação que acaba definindo os parâmetros para os estudos históricos.

Vico não se concentra no dogma, mas penetra fundo na metafísica do mito e da linguagem; a abordagem viquiana pretende ampliar alguns conceitos costumeiramente tidos como religiosos, identificando - no comportamento do ser humano - características que se

l'umanità, e per ciò si debbano santissimamente custodire da tutte perché 'l mondo non s'infierisca e si rinselvi di nuovo. Perciò abbiamo presi questi tre costumi eterni ed universali per tre primi principi di questa Scienza." La Scienza Nuova - Lib.I - Sez.III - De’ Principi - pág .143 
prestam à investigação científica. Sua preocupação em "colocar no mundo das letras” uma teoria que pudesse imprimir o caráter científico à história das línguas e à história das “coisas” encontra na filologia - típica ferramenta rabínica - uma razão de ser que se afina com o racionalismo contemplador italiano; com esse modo de argumentar, Vico traça a linha divisória entre as ciências exatas e humanas ${ }^{77}$.

"E com desejo de usar ( a Ciência) em beneficio da religião católica, Vico verificou não existir no mundo das letras um sistema que juntasse a melhor filosofia - a platônica , subordinada à religião cristã - e a filologia, com a qual a história das linguas e a história das "coisas" passam a ser consideradas ciências; pela história se comprova a história das línguas de tal forma que o sistema proposto faz conviver amigavelmente tanto as máximas dos sábios das academias como as práticas dos sábios das repúblicas." 78

Os métodos e critérios identificados pelo filósofo italiano para a validação das ciências humanas hoje são consagrados e usados pelas ciências que, na linguagem viquiana, subsistem como ciências filológicas. Para o estudo das ciências humanas, as letras são mais úteis do que os números; lendas e relatos antigos, trabalhados filologicamente, revelam tempos anteriores à própria palavra escrita, porque sugerem um universo de idéias que povoavam as mentes dos nossos antepassados mais longínquos. A filologia ${ }^{79}$ é a ferramenta de certificação com a qual Vico empreende sua busca por pressupostos universais e eternos presentes na cultura dos

77 G. Villa analisa o racionalismo contemplador de Vico, que é diametralmente oposto ao racionalismo construtor, típico da cultura anglo-saxonica. - VILLA, G. - "La filosofia del Mito secondo G.Vico” - Cap.VII: "Vico e la storia” - Pag 178

\footnotetext{
78 "E con desiderio di piegargli in uso della cattolica religione, Vico intese non esservi ancora nel mondo delle lettere um sistema, in cui accordasse la miglior filosofia, qual é la platônica subordinata allá cristiana religione, con la filologia che portasse necessita di scienza in entrambi le sue parti, che sono le due storie, una delle lingue, l'altra delle cose; e dalla storia si accertasse quella delle lingue, di tal condotta che si di fatto sistema componesse amichevolmente e le massime de' sapienti dell'academie e le pratiche de' sapienti delle reppubliche”. -"Vita di Giovanbattista Vico scritta da se medesimo” - VICO, Giambattista - “ Opere” - revisão de Fausto Nicolini

${ }^{79}$ O método filológico é consagrado pelos rabinos: a paixão pela língua e pela literatura os impulsiona a buscar na palavra, as justificativas filológicas. Contestadas ou não, as palavras decifradas constroem um tipo de pensamento que não pode ser considerado aleatório, assim como não podem ser descartadas como "nãocientíficas" ou simplesmente "fantasiosas" as argumentações rabínicas, uma vez que se revestem de autoridade crítica e buscam, na evolução das ciências, razões e teorias para corroborar o texto bíblico.
} 
povos da antiguidade e, em todos os casos investigados por Vico, a religião aparece como um fator desencadeante de cultura. A história da antiguidade, de maneira geral, em todos os tempos e em diferentes lugares, toma forma quando são estabelecidas as relações ente os homens e seus deuses e mitos.

\section{2 Do resíduo de textos sagrados}

As teorias sobre linguagem e religião, que segundo Vico são geradoras de cultura e não geradas por ela, podem ser analisadas à luz do trabalho de Eugène Nida ${ }^{80}$. Nas suas observações referentes às técnicas tradutórias, encontramos uma advertência quanto ao perigo da visão etnocêntrica por parte do mundo ocidental que impede a compreensão do outro cultural; no caso especifico de Nida, seu empenho em traduzir a Bíblia para mais de duzentos idiomas, inclusive línguas indígenas, acabou por definir o papel real da linguagem na sociedade e sua relação com a cultura. Nos cursos de técnicas tradutórias, seu trabalho aparece como referência e sua contribuição não pode ser ofuscada.

Nida defende a idéia de que é necessário procurar significados fixos ou essências em textos, a fim de garantir a fidelidade da mensagem autoral a ser transmitida de uma língua para a outra. A procura de significados fixos garante a preservação de um "resíduo”, com o qual podemos aceder às informações originais. Desde que sejam mantidos alguns critérios de "fidelidade" - que incluem uma visão despretensiosa do outro cultural -, o "resíduo" é responsável pela transmissão do conteúdo do texto de partida, mesmo que se perca boa parte da mensagem autoral.

No caso de textos considerados sagrados, o "resíduo" advém de um autor cuja origem é divina e, para a maioria dos tradutores, captá-lo torna-se uma empresa impossível. Eugène Nida, ao traduzir a Bíblia para centenas de idiomas, decidindo abraçar as dificuldades que toda transmissão de imagens e signos de uma língua para outra pode acarretar, tornou-se uma referência para os estudos de técnica tradutória ${ }^{81}$ e nos coloca diante da problemática da

\footnotetext{
${ }^{80}$ Eugène Nida (1914 - ) - E.U.A - Lingüista-antropólogo-missionário-tradutólogo

81 É claro que desde as primeiras traduções da Bíblia - a partir das tradições orais traduzidas para o hebraico, depois para o latim e desse para as inúmeras línguas existentes hoje, ocorreu uma impregnação de vocábulos
} 
conservação da memória judaica, registrada na Torá. Para os judeus - que preservaram suas memórias desde o princípio - o "resíduo" é aquilo que lhes confere a identidade de povo. Para a história dos gentios, Vico enfrentou a dificuldade de ter de recolher o material - até então considerado como lenda e fábula - buscando "traduzir“ a história que estava sendo contada por meio desses textos.

Avaliando o modo de argumentar de Vico que, assim como o dos rabinos, observa casos particulares, explorando as idéias sugeridas no texto, compreenderemos o pioneirismo desse grande filósofo, evidenciado nesta afirmação de Alfredo Bosi:

"Vico percebeu o caráter específico do discurso histórico que procede observando casos individuais e situações prováveis e infere tendências por meio de tópicos (topoi), em vez de obedecer a critérios de evidência e a regras dedutivas como as da Geometria fixadas desde e para sempre." 82

O discurso histórico possui um caráter específico que foi revelado na Ciência Nova. O pensamento metafísico de Vico (que se apóia na existência de um Deus criador e na separação dos povos entre hebreus e gentios), aliado à filologia (ferramenta de certificação da veracidade do fato), lança a teoria viquiana para além das especulações religiosas: observações de caráter mitológico, literário, histórico, jurídico, dão corpo às imagens aparentemente lendárias dos relatos "fabulosos". A atitude, pouco etnocêntrica e bastante especulativa de Vico ao interpretar o texto de Gênesis 6, (e os capítulos anteriores também) o conduz a uma concepção da história obscura do início adâmico e do recomeço gentílico que complementa ou oferece um novo aspecto além do naturalístico; assim fazendo, Vico dita as regras para o estudo da história e consegue faze-lo porque considera o modelo de aculturação judaico, que será verificado nas outras civilizações.

O historiador Flavio Josefo compila a história do povo judeu levando em consideração as tradições Jawista e Elohista $^{83}$; Vico re-compõe a história dos latinos

novos e, sem dúvida, boa parte da equivalência se perdeu. Acredita-se, porém, que o resíduo tenha sido preservado, tendo ou não sido ditado por "inspiração divina”. - “ Teorie contemporanee della traduzione”.

${ }^{82}$ A.Bosi - “O ser e o tempo da poesia”. Cap.: "Vico anti-Descartes”- pag.197

${ }^{83}$ As tradições Jawista e Elohista são as mais conhecidas popularmente. Durante as aulas da professora Ruth Leftel (USP/2006 - "História dos tempos bíblicos”), estudamos mais duas tradições: a do escritor de 
resgatando as tradições e textos antigos. A Torá foi contada, cantada e regularmente estudada nas sinagogas desde que se tem notícia da existência da comunidade judaica, e somente os conhecedores da língua santa puderam aceder à mensagem bíblica "residual” até que o Ocidente recebesse a tradução conhecida como Septuaginta (que Vico chama de "versione dei Settanta” ${ }^{84}$ ). Vico, embora não conhecesse outras línguas além do italiano e o latim ${ }^{85}$, entra em contato com a literatura judaica acessando as traduções e os comentários em circulação na sua época; acreditamos que o filósofo napoletano mantêve-se cuidadoso com relação ao seu interesse por textos e escritores condenados pela igreja católica. Podemos afirmar, no entanto, que o interesse de Vico pela história e pela literatura judaica ultrapassa o simples diletantismo e a busca por respostas às perguntas de caráter religioso: porque pretendia encontrar nos textos, sagrados ou não, o embasamento científico para seus postulados, GV empreende sua busca por pressupostos eternos e universais nas “mensagens residuais” dos relatos antigos; seu conhecimento eclético e filológico serão as ferramentas de base de seu trabalho, que naturalmente inicia-se pelo documento mais antigo: as memórias registradas pelo povo hebreu.

\section{3 A literatura judaica e as tradições Jawista e Elohista}

O "modus operandi" de Vico difere daquele adotado pelos "dotti di sapienza riposta ${ }^{86 ",}$, por ser centrado na reavaliação da mensagem residual e na adoção da filologia

Deuteronômio e a do relator . O ponto de partida, contudo, são as duas tradições mais antigas a que fazemos referência neste trabalho.

84 “94[...] Tudo isso cessa com a confissão pública dos hebreus, os quais com a versão dos Setenta..... quando saiu, houve três dias de trevas por todo o mundo, como foi observado nos livros rabinicos por Casaubuono em "Exercitações sobre os anais de Baronio", por Buxtorf em "Sinaghoga judaica e por Ottinger no Tesouro filológico”. - La Scienza Nuova - Lib.I.Sez.I -Annotazioni alla tavola cronológica - pág 75,76

${ }^{85}$ O historiador italiano Carlo Ginzburg, especialista na análise dos processos da Inquisição nos séculos XVI e XVII, Professor da Universidade de Bolonha e da Universidade da California em Los Angeles, esteve no Brasil, onde proferiu palestras a convite da USP, da Unicamp e do PPGAS do Museu Nacional (UFRJ) - Estudos Históricos; Rio de Janeiro, vol. 3, n. 6, 1990, p254 -263. Numa entrevista concedida a Alzira Alves de Abreu, Ângela de Castro Gomes e Lucia Lippi Oliveira, em setembro de 1989, o historiador Carlo Ginzburg cita Vico como uma exceção em sua época : “ Vico, por exemplo, não sabia francês, só sabia latim, viveu numa província longínqua e foi um grande gênio...”. - Disponível in: www.cpdoc.fgv.br/revista/arq/78 - Acesso em Dez/2006

${ }^{86}$ Isto é, “doutos de sabedoria re-elaborada”. 
como instrumento de certificação, com os quais rabinos e tradutores de textos sagrados e antigos também trabalham. A Ciência Nova debate temas referentes à história da civilização (conhecida como ocidental) tomando por base a história da formação da sociedade judaica, registrada na Torá e esclarecida no Talmude; ao discutir e esclarecer as Escrituras, o Talmude permanece como um instrumento de conservação da memória judaica e nesse tesouro infindável Vico pode ter mergulhado, pois os conceitos universais a respeito da formação dos povos e o estilo dialético dos rabinos parecem estar presentes na Ciência Nova.

Ao eleger a catástrofe diluviana como o marco que dá início às civilizações gentílicas, Vico se apóia no fundo de verdade “residual” extraído de lendas originárias de diferentes povos antigos, mas acreditamos que o relato do capítulo 6 da Gênesis, por fazer parte das tradições judaicas preservadas desde o princípio, ofereceu-lhe um ponto de apoio fundamental. Dentre todas as obras revalorizadas durante o fervilhar das idéias e teorias da Europa pós-renascentista, a literatura judaica certamente mereceu uma atenção particular para os estudos de Vico. Na verdade, a história dos judeus se confunde com sua literatura e, conhecer uma ou outra, nos leva a conhecer o modo de aculturação desse povo.

\section{3.1 Da história da literatura e da cultura judaica}

A língua e a cultura judaicas passaram por muitos momentos de crise: nos séculos VI e VII a.C., quando do retorno dos exilados judeus do Cativeiro da Babilônia para a terra de Israel, ocorre um primeiro renascimento; o segundo renascimento ocorreu na Idade Media na Espanha, na Itália e na Provença. Por volta de 900, descobriu-se que todas as comunidades judaicas usavam o hebraico como língua útil para a comunicação escrita - em livros, documentos jurídicos e cartas particulares, e houve também uma importante produção de obras na forma de poesia, prosa narrativa e escritos de caráter científico e filosófico. Dentre os mestres mais importantes, citamos Rabi Moshê Ben-Maimon (Espanha - séc. XI), símbolo do judaísmo sefardita, que influenciou grandes figuras do rabinato e Isaac Abravanel (século XVI). O grande filósofo judeu Abravanel defendeu o pensamento hebraico nos difíceis tempos da caçada da Espanha, assimilando os conhecimentos de Ben-Maimon e absorvendo 
também conceitos aristotélicos. Em meados do séc. XVII, com o movimento nascido na Alemanha e conhecido como Haskalah, os escritores promoveram a derradeira renovação do judaísmo e alguns nomes repercutiram também na Itália ${ }^{87}$; podemos citar Moisés Chayyim Luzzato, de Pádua (1707-47), e um dos modelos favoritos dos poetas do século XVIII em toda a Europa, Pastor Fido de Guarini, de quem Luzzato absorveu as características literárias e temáticas ${ }^{88}$.

Muito contribuiu para que crescesse o interesse pela cultura judaica a primeira tradução da Bíblia para a língua alemã: Martinho Lutero dá o passo inicial para que estudiosos ocidentais iniciassem pesquisas interessantes, uma vez que a veracidade de textos sagrados sempre foi alvo de especulação. Em 1753 o médico francês Jean Astruc ${ }^{89}$ financia e publica um livro, resultado de uma longa pesquisa, no qual são feitas "Conjecturas sobre as memórias das quais onde Moisés pode ter extraído as bases para escrever a Gênesis”. Astruc nota que, no primeiro livro do Pentateuco, ao lado das páginas em que Deus era chamado com o termo específico bíblico de Yaveth (impronunciável para os hebreus), existiam outras, nas quais Deus era chamado de Elohim, termo esse oriental e mais genérico. Desde então, estudiosos no assunto, fazendo uso de instrumentação sofisticada, submeteram os rolos do Pentateuco a uma radiografia literária, quase microscópica, procurando as várias camadas e fontes.

Descobriu-se que no folclore das vilas, nas catequeses, nas assembléias litúrgicas, no ensino dos pais aos filhos, as origens de Israel foram transmitidas e expostas ao conhecimento e à meditação das novas gerações mediante típicos procedimentos semíticos destinados a estimular e favorecer a memória.

O texto sagrado fora escrito primeiramente com apenas consoantes que indicavam a idéia a ser passada. As vogais eram adicionadas no momento em que o texto era ensinado às novas gerações, preferivelmente de pais para filhos, priorizando o contato físico no

\footnotetext{
${ }^{87}$ Uma pesquisa específica sobre o insediamento hebraico na Itália foi feita em 2002 pelo Prof.Dr. Michele Luzzati da Universidade de Pisa e revela que os estados italianos foram invadidos por centenas de insediamentos hebraicos entre 1200 e 1500. A maciça presença hebraica foi foco de numerosas pesquisas no século XIX. Revista cultura 200 - História judaica -Disponível em: culturajudaica.org.br. Acesso mar/2006.

${ }^{88}$ Conhecimento Judaico - Nathan Aurubel

${ }^{89}$ La Bibbia - Introduzione generale -
} 
aprendizado, que só poderia ser feito, portanto, verbalmente. Dessas correntes vivas de palavras, de imagens e de eventos aparecem dois tipos de tradição: a Jahvista e a Elohista. Dos escritos de Moisés e dos ensinamentos na memória coral do povo, guiado e iluminado por Deus - os hebreus - nasce, por volta do séc. X a.C., a primeira sistematização teológica dos textos orais, conhecida como tradição Jahvista - basicamente verbal e coral, cantada em versos, nos moldes da tradição da Lei das XII tábuas. A tradição Elohista aparece em IX-VIII a.C., mais rigorosa e sóbria, com características de documento escrito.

A definição de Astruc sobre a linguagem da tradição Jahvista nos faz pensar nas características que, de acordo com Vico, são típicas das fases divina e poética; e a tradição Elohista parece fazer parte da linguagem que Vico chama de articulada, fruto de uma sabedoria sedimentada, vulgar (do vulgo - povo) e divulgada - isto é, decorrente de outra sabedoria espontânea que a precede. Os hebreus se formaram como “povo” repassando suas memórias e contando suas histórias, com linguagens espontâneas que evoluíram no tempo. Vico deduz que todas as civilizações - que necessariamente vieram depois desse povo considerado o mais antigo - se formaram da mesma maneira, não por terem aprendido com os judeus, mas por ser esse o modo de aculturação característico da humanidade.

Apesar de não ter lido os originais, não nos é difícil deduzir que o filósofo italiano empreendeu uma análise sobre os textos bíblicos servindo-se de informações acadêmicas: na Ciência Nova, aparecem diversos nomes ligados à cultura judaica (que podem ser objeto de pesquisa posterior): Bochardt, Capistro, Marcus, Zoli, Botturi, Buxtorf, Ottinger, Casaubuono, Píer Cuneo, Lattanzio, Demetrio, Joseph Athias, Filon, Flavio Josefo e Judá Abravanel, conhecido na Europa como Leon Hebreo. Lemos ainda, num adendo à Autobiografia, sobre a amizade entre o filósofo italiano e o judeu Giuseppe Athias, um intelectual reputado e conhecedor da língua santa (o hebraico). Vico atribui a Giuseppe Athias a edição e explicação de um Velho Testamento em Amsterdã, obra famosa entre os acadêmicos e, embora o historiador italiano Arnaldo Momigliano ${ }^{90}$ conteste tal afirmação, dizendo que o velho testamento em questão teria sido editado por outro Joseph Athias (por volta de 1661), a discussão nos dá uma idéia da importância que se dava aos estudos

\footnotetext{
${ }^{90}$ Arnaldo Momigliano em Vico's Scienza nuova: Roman "Bestioni" and Roman "Eroi". History and Theory, Vol. 5, pag 9 - No. 1 (1966), pp. 3-23
} 
judaicos. ${ }^{91} \mathrm{O}$ judeu em questão - o livreiro Giuseppe Athias - é citado também num texto de outro historiador italiano, Salvatore Rotta; esse texto, que avalia a proximidade entre o pensamento de Vico e Montesquieu ${ }^{92}$, revela que a mansão de Athias em Livorno era frequentada por intelectuais como o filósofo francês.

Vico parece preferir os autores que, ligados ou não à cultura judaica, sustentam um mesmo tipo de pensamento no que se refere à crença em um Criador. Embora nenhum deles tenha unido a ciência divina e a ciência humana, as teorias de Tácito, Platão, Groz e Bacon, no julgamento do filósofo napolitano, se aproximam das teorias “divinas”; o esforço de Vico em vincular o divino ao humano define sua própria metafísica que dará forma e conteúdo a uma ciência nova: a história.

\section{II.3.2 Torá, Talmude, Midrash}

“A religião hebraica foi fundada pelo verdadeiro Deus na proibição da divinação (adivinhar) baseada na qual surgiram todas as nações gentílicas." (A Ciência Nova, pg.100)

"[...] existe a providência divina, sendo uma mente legisladora, que das paixões dos homens, todos presos às suas privadas utilidades, pelas quais viveriam como ferozes animais dentro das solidões, criou as ordens civis para viverem numa humana sociedade." (A Ciência Nova - pg.93)

A elaboração desses pensamentos aceita a prerrogativa de que o povo judeu é o primeiro povo a criar história sobre a face da terra a partir da revelação da existência de um único Deus Criador; essa experiência separa o povo judeu das demais nações que surgiram depois do dilúvio universal e que teriam seguido sua trajetória, desligadas das prescrições

\footnotetext{
91 “Aggiunta fatta dal Vico alla sua Autobiografia -1734 - Vita di Giovambattista Vico scritta da se medesimo $(1725-28)$

${ }^{92}$ S. Rotta, "Montesquieu nel Settecento italiano: note e ricerche", in Scritti scelti di Salvatore Rotta, Eliohs ${ }^{\circledR}$, ottobre 2003 http://www.eliohs.unifi.it/testi/900/rotta/rotta_montesettit.html. Acesso jan/2007
} 
ditadas pela “mente legisladora” - a mesma mente que regula a Mishná até os dias de hoje. O pensamento metafísico de Vico admite, portanto, a existência de um Ser Supremo que, ao manifestar-se, teria transmitido suas Leis a um povo eleito; a vontade e as exigências desse Deus foram reveladas a Moisés no Monte Sinai e o relato dos eventos encontra-se na Torá.

Israel obteve e obtém a revelação da Sabedoria e da Justiça divinas através da Torá, o livro sagrado que incorpora as exigências morais de um Deus que quer se relacionar com o homem. Vico tomará como modelo o processo de aculturação dos judeus - fundamentado em prescrições jurídico-religiosas - e identificará um "proceder" universal nas formas de aculturação dos outros povos.

Na Torá, os fatos que construíram e mantém a nação judaica são acertados filosófica e filologicamente: a Palavra de Deus, a Lei, ao ser estudada e dissecada através dos séculos pelos sábios que viviam em Israel e na Babilônia, dá origem ao rico “corpus” escriturário que compõe a literatura rabínica: Mishnah, Tossefta, Talmude de Jerusalém, Talmude da Babilônia, Midrash e Choul' han arouk. ${ }^{93}$

A Mishnah (séc. II) surge da necessidade de registrar a tradição oral de forma escrita para que toda a riqueza dos ensinamentos da Torá, até então transmitida oralmente pelos rabinos, não se perdesse. As leis orais, reunidas na Mishnah, foram exaustivamente estudadas pelos sábios palestinos e babilônicos que desenvolveram (nos séculos seguintes) dois corpos de comentários denominados Guemará. O conjunto de Mishnah e Guemará constitui o Talmude (que pode ser de Jerusalém ou da Babilônia - de acordo com o local em que foi gerada a Guemará) ${ }^{94}$.

A paixão pelo ensino e pelo estudo constitui uma das leis fundamentais do judaísmo. Ao discutir, esclarecer e explicar, os rabinos constroem, por meio da lógica e do raciocínio, conceitos que não desprezam os mínimos detalhes; não só as palavras, mas cada letra carrega um significado. As mensagens embutidas no texto vão revelando a história dos tempos passados: por meio da hermenêutica, da filologia, do conhecimento e capacidade intelectual dos estudiosos, o relato sagrado adquire valor de documento.

\footnotetext{
93 AZRIA,Régine - O judaísmo - pg.67

${ }^{94}$ RAFFALOVITCH, Is. - “Breve História da Literatura Judaica” - Coleção Judaísmo
} 
Assim como o os rabinos, o pensamento metafísico de Vico apóia-se na existência de um Deus criador, na separação dos povos entre hebreus e gentios e na adoção da filologia como ferramenta de certificação da veracidade do fato; o filósofo harmoniza e interpreta as observações de caráter mitológico, literário, histórico, jurídico e religioso de modo a corroborar o texto aparentemente lendário. Vico e os rabinos não se concentram no fato, mas em como ocorre o fato e, para tanto, procuram o "vero" - a verdade - na filosofia e o "certo" - a certeza - que o processo lingüístico pode fornecer mediante uma pesquisa filológica.

"A filosofia contempla a razão, de onde vem a ciência do verdadeiro (do que realmente aconteceu); a filologia observa a autoridade do arbitrio humano, de onde vem a verificação do certo."

"Este mesmo axioma demonstra que aos filósofos faltou uma metade de conhecimento por não terem se certificado com a autoridade dos filólogos assim como os filólogos não tiveram o cuidado de tornar verdadeiras as suas colocações com a razão dos filósofos; e se ambos o tivessem feito teriam sido mais úteis às repúblicas e seríamos poupados de meditar esta Ciência." 95

O fato histórico, que surge da mitologia analisada por Vico, evidencia o caráter do discurso histórico; tal caráter não foi evidenciado pelos naturalistas e os métodos e critérios criados por Vico parecem ter surgido de sua visão criacionista. A teoria viquiana sobre o mito revela a existência de um ser ferino que já é “mente, corpo e fala” ${ }^{96}$ e aponta para alguém que possui a intenção de construir e contar sua história: a primeira humanidade construiu a primeira história com fábulas - do italiano “favola” - e os judeus fundaram a primeira nação a partir das tradições conservadas e mantidas vivas por meio do repasse e do estudo das escrituras.

\footnotetext{
95 "138 La filosofia contempla la ragione, onde viene la scienza del vero; la filologia osserva l'autorità dell'umano arbitrio, onde viene la comienza del certo. 139.....Questa medesima degnità dimostra aver mancato per metà cosí i filosofi che non accertarono le loro ragioni con l'autorià de' filologi, come i filologi che non curarono d'avverare le loro autorità con la ragio de' filosofi; lo che se avessero fato, sarebbero stati piú utili alle reppubliche e ci avvrebbero prevenuto nel meditare questa Scienza" - La Scienza Nuova - Lib I Sez II Pag.95

96 “[...] non essendo altro l'uomo, propiamente, che mente, coprpo e favella.” La Scienza Nuova - Della Logica Poetica - in Opere (F.Nicolini).Pág. 930
} 


\section{3.3 O Midrash do dilúvio}

Se para Chayim Nachman Bialik ${ }^{97}$, “a Agadá ${ }^{98}$ está para a poesia assim como o Halachá para a prosa”, a Agadá pode ser considerada uma das fontes de onde Vico extraiu o conceito de " favola": a fábula representa, para o filósofo, a lenda com fundo de verdade, transmitida pela tradição oral. Para Vico, o homem bárbaro vive a poesia quando se relaciona com o divino, numa linguagem emocionada e irracional; o relacionamento social é estabelecido num momento seguinte, quando o homem $f a z$ poesia: os costumes, crenças e leis vão sendo estabelecidos como decorrência daquele momento inicial “divinatório”. A primeira humanidade registrou poeticamente os fatos criando as tradições orais e verbais e o relato bíblico propriamente dito surge na época de Moisés, numa linguagem posterior e mais elaborada, constituindo a base a ser dissecada pelos talmudistas.

Ao lado do Talmude desenvolveu-se outra literatura, que pode ser chamada de expressão poética ou espiritual do pensamento judaico, o Midrash ${ }^{\mathbf{9 9}}$. A palavra Midrash tem raiz na palavra "Darash”, que significa inquirir, investigar. Há dois tipos de Midrash: o Midrash Halachá (do qual os rabinos derivam leis a partir da Torá escrita, por meio de uma metodologia exegética pré-estabelecida) e o Midrash Agadá.

Toda a literatura judaica serve para que a palavra seja sempre lembrada e para que as leis sejam cumpridas. Bereshit Rabá pertence aos Midrashim (plural), compostos entre os séc. I e V d.C.. O Grão-Rabino dos Israelitas do Brasil, Isaias Raffalovitch, em 1934, nos dá uma idéia da profundidade do trabalho midrashico:

"Trata-se de uma compilação de exposições homiléticas ou espirituais da Bíblia, penetrando sob a superficie do sentido singelo do texto bíblico. Enquanto o Talmude

\footnotetext{
${ }^{97}$ Chayim Nachman Bialik (1873 - 1934) - Poeta, tradutor, ensaísta, contador de histórias, editor, um dos maiores poetas judeus de todos os tempos. Bialik é considerado poeta nacional de Israel, embora não tenha vivido para testemunhar o nascimento do estado de Israel.

${ }^{98}$ Agadá é todo o material presente no Talmud e fora dele que versa sobre temas de caráter não legal (Halachá) e abordam temas diversos (medicina, passagens bíblicas, folclore, etiqueta, ética, filosofia, astronomia, sabedoria popular, estórias, provérbios, parábolas, etc.). - Apontamentos das aulas do prof. Moacir Amâncio - Curso "Introdução à visão talmúdica de mundo" - USP

${ }^{99}$ Apontamentos das aulas do prof. Moacir Amâncio - Curso de Pós-graduação - “Introdução à visão talmúdica de mundo" - USP.
} 
se dedica principalmente à explicação da letra, o Midrash revela o espírito da palavra e da Lei. Os primeiros vestígios da literatura midráshica podem ser encontrados numa época anterior à conclusão da Bíblia, mas a sua atividade estendeu-se até o décimo ou undécimo século. Até os nossos dias, o Midrash serviu de tesouro inesgotável aos pregadores e moralistas judeus, ofereceu-lhes uma vasta série de engenhosos e sutis comentários de passagens bíblicas, embelezados com provérbios, parábolas e lendas. O ideal que serve de esteio ao conjunto desta literatura é o aperfeiçoamento da moralidade, o enaltecimento do princípio ético da vida, o apelo para a imaginação e a apresentação do lado espiritual do judaísmo numa forma atraente. Um grande número de obras midráshicas existe ainda hoje e, a despeito da sua antigüidade, goza até agora de grande popularidade, contando inúmeras edições." 100

Assim como os rabinos abordam o tema do dilúvio universal no Midrash Rabá ${ }^{101}$ argumentando sobre o episódio de modo a ratificá-lo, Vico não considera o episódio apenas do ponto de vista sagrado (teológico), mas extrai do texto bíblico as verdades históricas escondidas na poesia, não considerando, porém, a Bíblia como a única referência para apresentar a catástrofe como um marco histórico.

Teorias a respeito do dilúvio repercutiram e repercutem até hoje: segundo alguns teólogos, a Bíblia reelabora miticamente uma catástrofe mesopotâmica que gerou poemas mitológicos orientais como a famosa epopéia de Gilgamesh ou o poema de Atrahasis. Essa trágica recordação referia-se talvez a uma calamidade antiga e terrível que permaneceu por fragmentos na memória coletiva: algo que ocorreu entre o Tigre e o Eufrates.

Os registros dos livros de história da arte apontam para uma catástrofe que abalou os povos pré-sumerianos, ocasionada pela inundação dos rios da Mesopotâmia, que os especialistas relacionam com o dilúvio universal. A partir dessa catástrofe, Vico imagina o homem errante, vagando pela selva exuberante que se formara no terreno fértil; as características desse homem que se afastou da tradição adâmica são semelhantes àquelas do primata darwiniano, embora a contagem de anos seja conflitante. Para Vico a história do povo

\footnotetext{
${ }^{100}$ RAFFALOVITCH, I - “Breve História da Literatura Judaica” - Coleção Judaísmo

${ }^{101}$ Bereshitt Rabá pertence aos Midrashim compostos entre o séc. I o V século d.C.
} 
hebreu, por estar diretamente ligada àquilo que ele chama de “verdadeira religião”, possui um recomeço (pós-diluviano) ligado à tradição adâmica e à religião instituída por Enos (Gênesis IV); as tribos e as nações que se formaram depois do dilúvio determinaram novas tradições.

"O dilúvio universal é demonstrado não só pelas provas filológicas de Martin Scoock que são muito fracas e nem pelas astrológicas de Píer cardeal de Alliac, seguido de Giampico della Mirandola, que são incertas ou até falsas, pois se refazem às tábuas afonsinas, rebatidas pelos hebreus e agora pelos cristãos que desaprovam o cálculo de Eusébio e de Beda e seguem hoje o de Filon judeu, mas demonstra-se com histórias fisicas observadas nas fábulas, como nos postulados se elucidará." 102

102 “169 Il diluvio universale si dimostra non già per le pruove filologiche di Martino Scoockio, le quali sono troppo leggieri; né per l'astrologiche di Piero cardinale d'Alliac, seguito da Giampico della Mirandola, le quali sono troppo incerte, anzi false, rigredendo sopra le Tavole alfonsine, confutate dagli ebrei ed ora da' cristiani, $i$ quali, disappruovato il calcolo d'Eusebio e di Beda, sieguon oggi quello di Filone giudeo: ma si dimostra con istorie fisiche osservate dentro le favole, come nelle degnità qui appresso si scorgerà “- La Scienza Nuova - Lib I Sez II - Degli Elementi - pag 103 


\section{Capítulo III}

\section{A proposta viquiana sobre o começo das civilizações e os comentários rabínicos sobre o dilúvio universal}

Depois da análise do documento considerado mais antigo (a Torá) e de outros textos antigos e sagrados, Vico afirma que tudo começa com a religião. A memória judaica contém as idéias embrionárias de uma fase divinatória em que a religião é um fenômeno que gera a civilização; o material fantástico, coletado no livro do Gênesis e magistralmente re-elaborado por Vico, será a base para que sejam reconhecidos os pressupostos universais e eternos nas outras tradições. O filósofo considera como verdadeira a storia sagra ${ }^{103}$ porque no relato estão contidos dados passíveis de verificação científica; da interpretação filosófica e filológica desses dados surgem os postulados que serão aplicados e verificados nos relatos e lendas da antiguidade (sagrados e profanos) e os dados coletados por Vico lhe darão subsídios para que seja definido o caráter específico do discurso histórico.

Embora vinculado a uma doutrina religiosa, o esforço viquiano evidencia uma teoria sobre o mito que tornará possível a elaboração da história das idéias humanas desde os inícios mais obscuros. A teoria sobre o mito descortina a idéia que o homem adâmico tinha de sua realidade e evidencia o papel da fantasia criadora e da linguagem no processo civilizatório da humanidade; suas colocações partem de uma especulação religiosa, mas acabam fornecendo dados científicos sobre o comportamento humano e sobre a história, em que a Torá, eleita como a compilação das tradições mais antigas, será o documento sobre o qual o filósofo italiano começará a confirmar seus postulados, aplicando o método de verificação científica baseado no verum factum converturtur.

\footnotetext{
${ }^{103}$ Vico, na pg 102 da Ciência Nova, diz: “ 165 La storia sagra è più antica di tutte le più antiche profane che ci son pervenute” “(GLI ALTRI COROLLARI LI QUALI SI SONO DA PRINCIPIO PROPOSTI) - Ao afirmar que a historia sagrada é a mais antiga dentre todas as histórias profanas que chegaram até nós, Vico se atém ao fato de os hebreus terem conservado suas memórias desde o principio, apresentando registros passíveis de investigação como as tradições Elohista e Jawista; os patriarcas das outras nações - que conviveram com os patriarcas hebreus - atribuem a si próprios uma antiguidade tal que não condiz com as datas propostas pela história dos judeus. A Torá, por apresentar uma continuidade, passa a servir de base para que sejam comparadas as outras histórias.
} 
O fato ou a verdade, contidos na lenda, só podem ser revelados mediante o trabalho “rabínico” de filósofos e exegetas da qualidade de GV. Os rabinos discutiram e discutem suas origens e a identidade de seu povo porque sempre tiveram em mãos - ou nos ouvidos - os relatos de suas memórias. Vico resgata a memória da civilização latina, apostando na linguagem e na religião como fatores de aculturação, empreendendo o admirável trabalho exegético que possibilitará a visualização do começo da história da civilização ocidental; no relato dos primeiros capítulos de Gênesis parecem estar estabelecidas as características intrínsecas (os pressupostos) que seguirão os homens em todos os tempos e que os conduzirão a criarem novas tradições.

Da análise dos primeiros capítulos do Gênesis, à luz das relativas argumentações rabínicas, levantamos algumas semelhanças com os postulados - presentes na Ciência Nova referentes aos pressupostos universais e eternos. Os textos viquianos e judaicos parecem afirmar que: $1^{\circ}$ ) o homem se relaciona com a divindade; $2^{\circ}$ ) existem pressupostos eternos ou características intrínsecas que conduzem os homens a empreender um começo civilizatório por meio da religião; $3^{\circ}$ ) as civilizações se estabelecem a partir de três princípios universais e eternos (religião, casamentos e sepulturas); $4^{\circ}$ ) a história se desenvolve por fases; $5^{\circ}$ ) $a$ linguagem é o fenômeno que organiza o mundo.

Vico, mesmo acreditando na existência de um Deus criador, não usa a fé como justificativa para explicar o comportamento dos seres humanos; os pressupostos universais $e$ eternos são características comprováveis que induzem a humanidade a criar e perpetuar convenções que dão origem e mantêm as nações:

“[...] uma vez que este mundo de nações foi feito pelos homens, podemos ver quais coisas foram perpetuadas através de convenções e ainda persistem, pois tais coisas poderão dar os princípios universais e eternos, como devem ser em cada ciência, sobre os quais todas (as nações) surgiram e todas se conservam como nações." 104

\footnotetext{
104 “332 Or, poiché questo mondo di nazioni egli è stato fatto dagli uomini, vediamo in quali cose hanno con perpetuità convenuto e tuttavia vi convengono tutti gli uomini, perché tali cose ne potranno dare i principi universali ed eterni, quali devon essere d'ogni scienza, sopra i quali tutte sursero e tutte vi si conservano in nazioni." - La Scienza Nuova - Lib. I Sez. III - De’ Principi - pag. 143
} 
Na teoria viquiana, os postulados surgem da re-elaboração de dados coletados e, dentre os inúmeros postulados tecidos, evidenciaremos neste capítulo, aqueles que se relacionam à teoria sobre a formação das civilizações humanas, que possuem estreita afinidade com a visão judaica de mundo (expressa nos comentários rabínicos dos primeiros capítulos de Gênesis). Colocando os trechos da Ciência Nova, os versículos da Torá e as argumentações rabínicas em confronto, procuraremos denunciar, desenvolvendo os cinco itens mencionados acima, as afinidades de conteúdo e narrativa neles existentes. A história dos tempos obscuros, contada na Bíblia e arrazoada pelos talmudistas, evidencia um modo de aculturação que se afina com a proposta viquiana, a qual, distanciando-se do pensamento naturalista de seu tempo, posiciona a linguagem e a religião como fatores primordiais para a formação das civilizações.

\section{1 O homem se relaciona com a divindade}

“[...] o primeiro povo do mundo foi o hebreu e seu príncipe foi Adão, o qual foi criado pelo Deus verdadeiro com a criação do mundo." 105

"Estas são as origens dos céus e da terra, quando foram criados; no dia em que o Senhor Deus fez a terra e os céus, e soprou em suas narinas o fôlego da vida; e o homem foi feito alma vivente. E plantou o Senhor Deus um jardim no Éden, do lado oriental; e pôs ali o homem que tinha formado". 106

“A Torá, em sua primeira porção, traz a idéia do ser humano a partir de sua maior qualidade: criado à imagem de Deus". ${ }^{107}$

\footnotetext{
105 "51 [...] che 'l primo popolo del mondo fu egli l'ebreo, di cui fu príncipe Adamo, il quale fu creato dal vero Dio con la criazione del mondo. " - La Scienza Nuova - Lib. I - Sez. I - Annotazioni alla tavola cronologica nelle quali si fa l'apparecchio delle materie - pag. 51

${ }^{106}$ Biblia Sagrada - Gênesis 2 -7-8

107 “O midrash da criação" - Disponível in: <htpp//www.str.com.br/Scientia/origem.htm> . Acesso set 2005. Utilizamos alguns sites judaicos por transcreverem as argumentações rabínicas em italiano ou em português.
} 
"O Midrash - livro de profundo misticismo disfarçado em histórias alegóricas explica que o Todo-Poderoso criou um universo fisico porque desejava ter uma Morada aqui em nossa realidade terrena." 108

Vico acredita que a natureza e o homem foram criados por Deus e que existem características no ser humano que podem ser investigadas pela ciência. Mesmo que a existência e o ato da criação se apresentem, para Vico, como um conceito primitivo e inquestionável, a relação que os homens estabelecem com a divindade - criada ou não - será investigada. O primeiro falar dos poetas teólogos, pela onomathesia ou por meio da fantasia criadora que dá forma às idéias, denuncia o anseio de comunicação do homem com o mundo; dessa forma a pesquisa viquiana revela que o relacionamento do homem com Deus é um pressuposto porque será constatado em todas as civilizações. E ainda que partam de uma proposta fundamentada em um pensamento criacionista e que se relacionem de maneira direta com o conteúdo do Gênesis, tanto a teoria viquiana quanto a visão talmúdica de mundo investigam, elucidam e apresentam questões que podem ser objeto de ciência.

O criacionismo científico de Vico é identificado pela distinção que o filósofo faz entre pressupostos e princípios eternos: dos primeiros - criados por Deus - derivam os seguintes criados pelos homens. Na Ciência Nova, o homem aparece como o artífice da história e o "Verum factum" 109 passa a ser o conceito filosófico que equaciona o que é verdadeiro com o que é produzido: Deus conhece o mundo porque o cria continuamente e o homem conduz seu próprio destino porque conhece a história que faz. O homem faz a história segundo as idéias de sua mente, idéias, que num momento "fanciullo", baseiam-se no mito e na poesia que o revela.

Mito e poesia contrapõem-se ao "penso logo existo" ${ }^{110}$ : o homem, exercitando a fala, reconhece as coisas e aprende a pensar, organizando o mundo à sua volta. Nesse processo,

\footnotetext{
108 TRADIÇÕES E COSTUMES por Schlesinger Erma C. Disponível em: <htpp//www.visaojudaica.com.br. Acesso em abril/2006.

${ }^{109}$ A antiquíssima sabedoria dos itálicos - Opere - F.Nicolini. Pág 131

110 "Verum factum” - Mito e poesia revelam que o homem existe antes de refletir com mente pura e uma vez que $o$ verdadeiro e o que se faz se convertem um no outro, só será verdadeiro aquilo que o homem pode conhecer. De acordo com a premissa metodológica do verum factum, o homem não pode conhecer-se a si mesmo, como
} 
deixa marcas e registros, que podem ser resgatados nos resíduos das mensagens poéticas que produz. Para Vico e para os rabinos, as mitologias são os registros antigos das idéias e da história humana: ambos acreditam que a primeira humanidade começou com Deus e ambos acreditam que, nas memórias e tradições, o fato histórico pode ser re-elaborado.

"Por tudo isso temos que começar por alguma concepção de Deus e dela os homens não podem se privar, ainda que selvagens, ferozes e atrozes. Demonstramos que a concepção é esta: que o homem, caído em desespero por não ser socorrido pela natureza, deseja algo de superior que possa salvá-lo. "111

Nos textos da Ciência Nova e do Talmude, a religião é o ponto de partida para investigações de toda natureza. Vico, além de acreditar que a primeira humanidade começou com Deus, professa que todas as civilizações, mesmo sem se conhecerem, também começam com algum conhecimento de Deus.

\section{2 Os pressupostos eternos ou características intrínsecas que conduzem o homem a empreender um começo civilizatório por meio da religião}

\section{2.1 A capacidade de se comunicar, o caráter sociável, o livre-arbítrio e o senso comum.}

“[...] porque tal primeiro falar, que foi o dos poetas teólogos, não foi um falar segundo a natureza dessas coisas (como deve ter sido a língua sagrada criada por

pretendeu Descartes. Vico acredita que o cógito é apenas a consciência do próprio ser e não a sua ciência. Consciência e ciência constituem coisas distintas. A primeira pode ser possuída pelo ignorante, mas a segunda não, pois se trata do conhecimento verdadeiro fundado sobre suas causas.

111 “339 Per tutto ciò dobbiamo cominciare da una qualche cognizione di Dio, della quale non sieno privi gli uomini, quantunque selvaggi, fieri ed immani” -La Scienza Nuova - Lib.I. Sez.IV - Del método - pág . 149. 
Adão, a quem Deus concedeu a divina onomathesia, ou seja, a imposição dos nomes às coisas, segundo a natureza de cada uma)" ${ }^{112}$

"Deus trouxe os animais que formara da terra para que o homem os nomeasse. Deu nome o homem a todos os animais domésticos, às aves dos céus e a todos os animais selvagens." 113

"A Parashát Bereshit (No Princípio) representa, entre outras coisas, um microcosmo da história originária do Homem. A Torá, em sua primeira porção, traz a idéia de ser humano a partir de sua maior qualidade: criado à imagem de Deus, com a habilidade de se comunicar com Ele." 114

Vico apresenta como característica intrínseca e primordial no homem a capacidade de se comunicar, que acontece num momento anterior à fala; tal capacidade está vinculada a outras características como o caráter sociável, o livre-arbitrio e o senso comum. O começo divinatório denuncia a ânsia do homem pelo conhecimento do mito, fenômeno que desencadeia a comunicação e a socialização, que se fazem mediante escolhas e consenso; há uma predisposição biológica e um padrão de comportamento que conduzem o homem a se relacionar e criar convenções.

No comentário rabínico encontramos a habilidade de se comunicar do homem como uma capacidade biológica que o auxilia a pensar e escolher:

“A Torá, em sua primeira porção, traz a idéia de ser humano partir de sua maior qualidade: criado à imagem de Deus, com a habilidade de se comunicar com Ele. Também retrata, logo no início, o seu maior defeito: desobedecer às ordens de Deus, até o ponto em que decide cometer delitos terriveis, como assassinato e idolatria." 115

\footnotetext{
${ }^{112}$ La Scienza Nuova - pág. 189 - Nota já citada anteriormente

${ }^{113}$ Gen 2:19- Bíblia Sagrada

114 As observações baseiam-se nos livros de rabinos como Rabbi Elie Munk, Yishai Rosh Chasidah Hashana, Rabbi Yaacov Culi (1689-1732) - Disponível in http://penei.org/vocab/vocab-yetzer.shtml . Acesso em set/2006

115 “O midrash da criação” - www.netjudaica.com.br. Acesso set/2006
} 
Vico e os rabinos enxergam no relacionamento da criatura com o criador o germe da primeira manifestação humana, que vincula o ato de falar ao anseio de se comunicar com a divindade. O relato bíblico não explica como a comunicação acontece, o que permite aos lingüistas, como Umberto Eco, suporem a existência de uma língua semelhante à dos pássaros ou falada pelos anjos, com a qual foi possível a recepção do preceito "não comerás do fruto da árvore do bem e do mal"; Adão nomeia os animais que Deus havia formado da terra, comunicando-se e organizando o mundo por meio da linguagem. A Adão é dada a oportunidade de escolher comer ou não da árvore do bem e do mal e, embora ainda não exista culto ou cultura, a captação do preceito caracteriza a existência de um esquema de ordem hierarquizado em que a criatura depende do criador e se comunica com Ele. O conhecimento do bem e do mal por conta própria (após a queda) dá início à cultura que será transmitida por caracteres poéticos, uma vez que, os homens, segundo Vico, começam naturalmente a pensar com os caracteres poéticos.

"[...] as crianças, com idéias e nomes de homens, mulheres ou coisas que olham pela primeira vez, aprendem ou dão nome, em seguida, a todos os homens, mulheres e coisas que possuem alguma semelhança ou relação com aquilo que viram pela primeira vez e esta é a primeira fonte dos caracteres poéticos, com os quais naturalmente pensaram os primeiros povos." 116

Josefo repassa a idéia de que seu povo conservou as memórias desde Adão servindo-se de colunas ${ }^{117}$; o Midrash deduz que o homem adâmico, além de verbalizar suas idéias, possuia a capacidade de registrar seus conhecimentos mediante um alfabeto, que pode ser considerado um tipo de registro feito através dos caracteres poéticos de que fala Vico.

\footnotetext{
116 “412[...].i fanciulli con l'idee e nomi d'uomini, femmine, cose, c'hanno la prima volta vedute, apprendono ed appellano tutti gli uomini, femmine, cose appresso, c'hanno con le prime alcuna simiglianza o rapporto", e che questo era il naturale gran fonte de' caratteri poetici, co' quali naturalmente pensarono e parlarono $i$ primi popoli”. - La Scienza Nuova - - Lib. II Sez II - Lógica Poética - pág. 196

${ }^{117}$ Na pág. 51 da Ciência Nova ( ponto 49 - Lib I. Sez.I ) Vemos que Vico conhece a passagem de Josefo que fala das colunas e parece não acreditar nelas, embora ele próprio admita que os homens , desde os inícios, devem ter utilizado caracteres ou signos para registrar suas memórias.
} 
"A Adão foi dada a habilidade de pensar e expressar seus sentimentos através da palavra. O Midrash conta que o primeiro homem, utilizando-se do alfabeto hebraico, deu nomes aos animais a ele mesmo e, finalmente, ao Todo-Poderoso." 118

Vico afirma que "os homens são naturalmente levados a conservar as memórias das leis e das ordens que os mantêm dentro das suas próprias sociedades" ${ }^{119}$; o filósofo enxerga o homem, ainda num estágio ferino ou primitivo, que quer falar ${ }^{120}$ e se relacionar, celebrando seu caráter sociável com algum tipo de comunicação. A capacidade de falar, registrar e repassar os fatos procede, na teoria viquiana, de uma programação mental religiosa, característica que estabelece a diferença biológica fundamental entre os humanos e os primatas em geral: Deus teria disposto as coisas humanas em função de capacidades biológicas e psíquicas que conduzem a criatura a agir, interagir, decidir e escolher em função de seu caráter social-religioso. Escolhas e decisões acontecem antes de qualquer ato reflexo, quando o “ânimo perturbado e comovido” prevalece e antecede a razão:

"Este mesmo axioma [...] prova que o homem possui livre arbitrio, porém, fraco, que faz das paixões virtudes; mas é ajudado naturalmente por Deus com a divina providência e sobrenaturalmente pela da divina graça." ${ }^{121}$

No ambiente paradisíaco do Gênesis, a impressão “perturbada e comovida” humana é identificada na alma feminina; a mulher é atraída pela busca por entendimento:

\footnotetext{
118 "O midrash da criação" - www.netjudaica.com.br - www.morasha.com.br - As observações baseiam-se nos livros de rabinos como Rabbi Elie Munk, YishaiRosh ChasidahHashana, Rabbi Yaacov Culi.Acesso set/2006.

119 "201 Os homens são naturalmente levados a conservar as memórias das leis e das ordens que os mantém dentro de suas sociedades. ” - La Scienza Nuova - Lib I Sez II - Degli Elemento - pag 111

${ }^{120}$ Vico cita na Ciência Nova a potencialidade de falar do homem ligada ao desenvolvimento das fibras vocais La Scienza nuova - ponto 231 Lib I Sez II egli Elementi - pag 116.

121 "136 Questa medesima degnità, congionta con la settima e 'l di lei corollario, pruova che l'uomo abbia libero arbitrio, però debole, di fare delle passioni virtù; ma che da Dio è aiutato naturalmente con la divina provvedenza, e soprannaturalmente dalla divina grazia."- La Scienza nuova - Lib I . - Sez II. - Degli Elementi - pág 95
} 
"Vendo a mulher que a árvore era boa para se comer, agradável aos olhos e árvore desejável para dar entendimento" 122

A explicação rabínica se aproxima da teoria viquiana relativa à metafisica della mente e chama de "tendência” aquilo que o filósofo italiano classifica como pressuposto:

(Bereshit) Também retrata, logo no início, o seu maior defeito: desobedecer às ordens de Deus, até o ponto em que decide cometer delitos terriveis, como assassinato e idolatria.

"Bereshit coloca em confronto, frente a frente, tanto o potencial humano em se elevar e fazer o que é Bom (Yétser Hatóv), até a nossa capacidade destrutiva, baseada em nossa tendência para o Mal (Yétser Hará)." 123

Os rabinos vinculam as tendências à doutrina da graça e Vico coloca o pressuposto do "livre arbítrio" vinculado às escolhas do período adâmico, fator que condicionará a humanidade a seguir seus destinos civilizatórios; nessa trajetória, os pressupostos acompanham os homens para que desenvolvam suas culturas e religiões. A idéia de graça como favor divino - expressa no projeto inicial do Gênesis - subsiste na era pós-diluviana em que os homens se orientarão com alguma referência divina, porém tateando para poder redirecionar suas vidas fora de um ambiente paradisíaco; vivendo solitários, como feras, os homens tiveram de encontrar um modo de conservar-se em sociedade, celebrando sua própria natureza sociável e desenvolvendo um tipo de direito "in natura”. No trecho abaixo podemos verificar o modo viquiano de conciliar a teoria antropológica com a religiosa:

"[...] os homens perdidos tornaram-se gigantes para que, no seu vaguear ferino, conseguissem suporta - sendo robusto - a inclemência do céu e das estações e para que pudessem, com força descomunal, penetrar na grande selva da terra, que pelo recente dilúvio devia ser serradíssima, pela qual [...] fugiam das feras e perseguiam

\footnotetext{
${ }^{122}$ Gen 3:6 - Bíblia Sagrada

${ }^{123}$ Disponível in: www.netjudaica.com.br e penei.org/vocab/vocab-yetzer.shtml . Acesso em set/2006.
} 
as esquivas mulheres, procurando pasto e água, dispersaram-se; mas em seguida começaram com suas mulheres a assentar-se, primeiro nas espeluncas, depois nas cavernas em seguida perto de fontes (...) e, por fim nos campos ao começarem a cultivá-los, quando a estatura foi se tornando menor e mais próxima da que conhecemos como humana." 124

Para Vico, e para os rabinos, as coisas teriam sido dispostas segundo um propósito eterno de forma que os povos pudessem confirmar aquilo que vem sendo constatado pela antropologia, isto é, que os homens saem de um estado ferino e errante, procurando assentarse, orientando-se e tomando suas decisões segundo um desenho funcional. O desenho funcional - os pressupostos universais e eternos ou características intrínsecas humanas - os conduz a criar seus deuses, suas ordens, leis e juízos. O Midrash do começo - que considera a Parashát Bereshit como uma representação de um microcosmo da história originária do Homem - sugere também um desenho funcional no qual vemos as tendências inerentes ao homem. O vocábulo Yetzer (inclinação) se desenvolve em duas categorias de desejos, com as quais o intelecto humano convive desde sempre e decide perder ou não o favor divino (a graça). As tendências acompanham os seres humanos e delas deriva a definição de pecado para os judeus:

\footnotetext{
"O termo rabínico mais comum para pecado é "averá" da raiz "avar" -

"sobrepassar"- e é interpretado como uma perda do favor divino. Os judeus

acreditam que o pecado é causado por uma inclinação para o mal (yetzer ha'rá), uma força que nos faz agir irresponsavelmente e sem medir as conseqüências. O ha'tov do yetzer, "a inclinação boa", é o oposto. ${ }^{125}$
}

\footnotetext{
124 “524 [...] gli uomini perduti provenissero giganti, acciocché nel loro ferino divagamento potessero con le robuste complessioni sopportare l'inclemenza del cielo e delle stagioni, e con le smisurate forze penetrare la gran selva della terra (che per lo recente diluvio doveva esser foltissima), per la quale (affinché si truovasse tutta popolata a suo tempo), fuggendo dalle fiere e seguitando le schive donne, e quindi sperduti, cercando pascolo ed acqua, si dispergessero; ma, dappoi che incominciarono con le loro donne a star fermi, prima nelle spelonche, poi ne' tuguri, presso le fontane perenni (come or ora diremo), e ne' campi, che, ridutti a coltura, davano loro il sostentamento della loro vita, per le cagioni ch'ora qui ragioniamo, degradassero alle giuste stature delle quali ora son gli uomini".- La Scienza Nuova - Lib II Sez IV Cap I - Iconomia poética - pag. 265

${ }^{125}$ Disponível in: www.netjudaica.com.br e penei.org/vocab/vocab-yetzer.shtml . Acesso em set/2006.
} 
Vico afirma que a mente maravilhada, ${ }^{126}$ ao observar coisas extraordinárias da natureza (como cometas ou estrelas ao meio dia), começa a indagar; a curiosidade que induziu Eva induzirá também o "bestione” a se perguntar sobre o fenômeno atemorizante do raio. Questionamentos e escolhas fazem parte da natureza humana e, na história dos hebreus, a escolha que dividirá a humanidade determinará dois rumos distintos para a história. A história que Vico diz mancare nei suoi principi, ou seja, a história dos inícios que faltava, é a história sagrada, na qual os hebreus explicaram detalhadamente suas necessidades e anseios. 127

“[...] como por toda esta obra será demonstrado que os começos (incominciamento) nasceram das necessidades públicas ou utilidades dos povos e depois, aplicando-se na reflexão dos particulares, os homens se aperfeiçoaram. E, portanto a história universal tem de ter um começo, que os doutos dizem faltar nos seus inícios." 128

Ao justificar a divisão do mundo antigo entre hebreus e gentios, Vico se apóia no fato contado na história sagrada e parte de um conceito metafísico, ligado à graça e ao livrearbítrio. A divisão, consolidada depois do dilúvio, já estava sendo delineada na era adâmica, com a classificação da humanidade entre pios e ímpios. Os nossos antepassados pósdiluvianos, representados pelos filhos de Noé, definem suas escolhas e crenças, orientados pela "piedade” ou pela "impiedade”: Cam e Jafet puderam exercitar o livre-arbítrio (yetzer), mas parecem ter preferido dispensar a ajuda sobrenatural divina. De acordo com as escolhas

\footnotetext{
${ }^{126}$ Um Midrash relata que a Serpente pega e come um pedaço da fruta da Árvore, sorri e diz à mulher: "Comi da fruta e D'us não me fulminou com a morte! Com certeza, tu também não morrerás". A Serpente insiste, tentando seduzir Eva a cometer o pecado, e diz: "No dia em que comeres o fruto desta árvore, teus olhos se abrirão. Serás como D'us". - www.netjudaica.com.br - www.morasha.com.br - O Anjo do Mal, incorporado na Serpente, apela para a curiosidade do ser humano, propriedade que não deixou de ser comentada por Vico: "A curiosidade, propriedade inata do homem e filha da ignorância, gera a ciência e, ao abrir a nossa mente, causa estupor”, (ou maravilha na linguagem viquiana). - La Scienza Nuova - Lib I Sez II - Degli Elementi - ponto 189 - pag. 107

127 “165 A história sagrada é a mais antiga de todas que chegaram até nós, porque tão explicadamente e por longo período de mais de 800 anos o estado da natureza na época dos patriarcas, ou seja, o estado das famílias” La Scienza Nuova Lib I Sez II - Degli Elementi - Pag.102

128 La Scienza Nuova - Lib I Sez I - “Annotazione alla tavola cronológica” - pag 53
} 
feitas num passado obscuro houve um lento distanciamento dos propósitos divinos, fazendo gerar as civilizações gentílicas. ${ }^{129}$

Vico coloca os hebreus como herdeiros da tradição gerada pelo Deus verdadeiro e, assim como a atitude de aceitação das prescrições divinas faz nascer a civilização judaica, a atitude de rebelião não possibilita a continuidade das tradições adâmicas depois do dilúvio e faz nascer as civilizações gentílicas. Com a palavra "incominciamento" Vico posiciona o início da civilização gentílica, assim como os rabinos identificam uma atitude de rebelião e mudança de comportamento no verbo "começar”. Para os judeus, o conceito de pecado ou transgressão é decorrente de uma atitude de rebelião e a interpretação rabínica do Midrash Rabá de Gênesis busca outros textos em que aparece o verbo começar:

"E aconteceu que, como os homens começaram a multiplicar-se sobre a face da terra (Gen 6,1) R. Simon disse: Em três lugares esse termo é usado no sentido de rebelião (contra Deus): E então se começou a invocar o nome de Deus (ib. 4,26; Ele (Nimrod) começou a ser poderoso na terra (ib. 10,8)). Uma objeção foi levantada: Mas isto está escrito. "E isto é o que começaram a fazer (ib.11,6)". Ele replicou: (Deus) destruiu a cabeça de Nimrod, exclamando "Esse é quem incitou - os a rebelar-se contra mim!" 130

O trecho do Midrash refere-se às três transgressões: a primeira acontece durante a geração de Enos (neto de Adão), quando se “começou a invocar o nome do Senhor”, numa alusão à adoção de cultos e ritos sacerdotais humanos; na segunda transgressão, a geração corrompida começa a multiplicar-se sobre a face da terra, sem o compromisso de matrimônio e na terceira - depois do dilúvio - o poderoso Nemrod que, depois de construir uma cidade, incita a rebelião contra o poder de Deus, gerando o episódio de Babel. A explicação rabínica

\footnotetext{
${ }^{129}$ A yezer há-ra é uma tendência que os rabinos identificaram desde o episódio no qual Adão e Eva têm a opção de aceitar ou não o mandamento de D’us. “O grande estudioso Judeu da Idade Média, Maimonides escreveu: "Todo homem tem potencial se de se tornar tão justo como Moisés, nosso professor, ou tão amaldiçoado como Jeroboão; sábio ou estupido; bondoso ou cruel; miserável ou generoso. O Judaísmo ensina que somos todos capazes de dirigir nossas próprias vidas, de escolher o caminho da retitude, ou seu oposto, o caminho do pecado ”- Disponível in: www.netjudaica.com.br . Acesso em set/2006
}

${ }^{130}$ Midrash Rabá - Gênesis (Bereshith) -cap XXVI- pg 211- ponto 4. Em hebraico o verbo começar possui analogia com o verbo rebelar-se. 
do trecho acima supõe, explicando a expressão "multiplicar-se sobre a face da terra”, o derramamento de sêmen sobre as árvores e pedras, ilustrando o comportamento de luxúria em contraposição ao previsto pelas leis divinas. O primeiro versículo do Gênesis 6 descreve o homem começando a multiplicar-se e com tal ato, interpretado pelos rabinos como um ato de rebeldia, começa a delinear-se aquilo que dará forma à civilização gentílica que, de acordo com a teoria viquiana, será registrada por caracteres poéticos distintos daqueles "santos”, usados pelos primeiros homens; as formas de registro ou representação passam a ser fruto da fantasia criadora do homem, que a Bíblia coloca como a imaginação dos seus pensamentos 131.

Vico põe o episódio do dilúvio como um começo para a humanidade gentílica que escolhe iniciar algo por conta própria ou pelo menos sem nenhum vínculo com as tradições adâmicas. Os gentios serão os descendentes de Cam e Jafet, que recomeçaram a vida depois do dilúvio sem levar em conta as leis adâmicas, fazendo com que as gerações seguissem seu rumo, dispersando-se pela floresta que começava a ser frondosíssima. Haverá um novo momento divinatório que conceberá a poesia que conta, por meio da mitologia, os fatos repassados pelas tradições orais; aparecerão os feitos heróicos e as epopéias e a imaginação caminhará distante do primeiro contato divinatório; os homens aprenderão a refletir e conduzirão suas vidas de acordo com suas convicções e modos de pensar; a linguagem se desenvolverá, articulando-se e articulando os pensamentos, que caminham para a abstração.

"Como os homens começaram a multiplicar-se sobre a terra, e lhes nasceram filhas, viram os filhos de Deus que as filhas dos homens eram formosas e tomaram para si mulheres de todas as que escolheram. Então disse o Senhor: não permanecerá o meu Espirito para sempre com o homem, pois este é mortal; os seus dias serão cento e vinte anos." 132

"MULTIPLICAR-SE SOBRE FACE DA TERRA - "ISso ensina que eles espalharam seu sêmen sobre as árvores e pedras"

\footnotetext{
${ }^{131}$ E viu o Senhor que a maldade do homem se multiplicara sobre a terra e que toda a imaginação dos seus pensamentos de seu coração era só má continuamente. - Gênesis 6:5 - Bíblia sagrada

${ }^{132}$ Gênesis 6:1-3 - Bíblia Sagrada
} 
Os rabinos fazem conjecturas em torno do verbo "multiplicar-se" (sobre a face da terra). É reconhecido um ato de luxúria ou comportamento sexual anômalo nessa multiplicação, no qual o sêmen teria sido depositado sobre a terra - isto é, sobre as rochas e árvores. Os homens escolheram dentre as mulheres as que mais lhes agradavam, numa postura de rebelião para com o matrimônio dentro dos padrões da lei adâmica e Vico apresenta opinião semelhante à dos rabinos, no que se refere aos costumes que vão sendo adotados pela geração que antecede o dilúvio:

"A opinião de que os concubitos (coitos), realmente efetuados, de homens livres com fêmeas livres sem nenhuma solenidade de matrimonio não contenham nenhuma malicia é falsa e não reflete a opinião das nações do mundo a julgar pelos seus costumes, que demonstram serem celebrados religiosamente e assim classificam como pecado animalesco as uniões sem celebração." 133

As leis que regulam as sociedades, de maneira geral, apresentam a prática de uniões e casamentos solenes; as alianças acontecem num estágio seguinte ao estágio que Vico chamaria de "animalesco” (di bestia). As regras vão sendo estabelecidas pelo senso comum, que, para Vico, é o dispositivo que permite o domínio das paixões e instintos, para que o homem possa conduzir a vida de acordo com as necessidades comuns.

"O arbitrio humano, por natureza incertissimo, se acerta e se determina com o senso comum dos homens, relativo às necessidades e utilidades humanas, que são as duas fontes do direito natural das gentes." 134

Na teoria viquiana o senso comum aparece como um juízo desprovido ainda de reflexão e, portanto, como um pressuposto que, aliado às demais tendências e capacidades, conduz o homem ferino em direção à sua emancipação: o homem, falando e escolhendo,

\footnotetext{
133 “336 L'oppenione poi ch'i concubiti, certi di fatto, d'uomini liberi con femmine libere senza solennità di matrimoni non contengano niuna naturale malizia, ella da tutte le nazioni del mondo è ripresa di falso con essi costumi umani, co' quali tutte religiosamente celebrano i matrimoni e con essi diffiniscono che, 'n grado benché rimesso, sia tal peccato di bestia." - La Scienza Nuova - Lib I - Sez III De’ Principi - pág 145

134 “141 L'umano arbitrio, di sua natura incertissimo, egli si accerta e determina col senso comune degli uomini d'intorno alle umane necessità o utilità, che son i due fonti del diritto natural delle genti.” - La Scienza Nuova Lib I Sez II - Degli Elementi - pág 96
} 
organiza-se com leis advindas de usos e costumes, aceitos pelos grupos ou tribos que estabelecem suas convenções, acordos e estatutos. ${ }^{135}$

"O senso comum é um juizo sem nenhuma reflexão, comumente sentido por toda uma ordem, por todo um povo, por toda uma nação ou por todo o gênero humano." 136

Para Vico, o senso comum é fonte do direito, uma vez que as leis nasceram do interior de cada cultura, visando a utilidade específica de cada nação; o filósofo napolitano era contrário à idéia de que os povos repassavam seus conhecimentos uns aos outros e, na verdade, propõe que o desenvolvimento histórico de uma comunidade, em qualquer lugar do planeta, segue algum tipo de padrão pré-estabelecido.

O mesmo padrão planta o senso comum na mente do homem que caminha em direção ao progresso: de uma fase divinatória para a uma fase heróica, as leis criadas fazem aparecer os conceitos de justiça e virtude como componentes de um momento de emancipação e préreflexão da sociedade.

\section{3 As civilizações se estabelecem a partir dos três princípios universais e eternos (religião, casamentos e sepulturas).}

"Todas as nações têm alguma religião, todas contraem matrimônios solenes e todas sepultam seus mortos; as nações, as mais selvagens ou "cruas", celebram com

\footnotetext{
135 Giuseppe Modica tece um comentário em que os pressupostos e os princípios (religião, matrimonios e sepulturas) são decorrentes do senso comum: "na Ciência Nova é regra da sabedoria popular ou até mesmo norma de civilização. Às vezes apareece como "certeza de autoridade» e o "criterio para definir o certo», a «sabedoria popular» e a «regra da sabedoria popular», o «uniforme» de que se deleita a mente humana e a própria mente que se deletia do uniforme, os três «sensos comuns» da Ciência Nova (religião , matrimônios e sepulturas) e o próprio plexo de onde derivam, o plexo das nações e medium entre providencia e livrearbitrio". - Introduzione a Giuseppe Modica - La filosofia del «senso comune comune» in Giambattista Vico Caltanissetta-Roma, Sciascia, 1983. Disponível em: http://www.unipa.it/ gmodica/sensocom.htm. Acesso em jan/2007

136 “142 Il senso comune è un giudizio senz'alcuna riflessione, comunemente sentito da tutto un ordine, da tutto un popolo, da tutta una nazione o da tutto il gener umano.” - La Scienza Nuova - Lib I Sez II - Degli Elementi - pág. 96
} 
solenidades, até mais ricas e detalhadas, as religiões, os matrimônios e as sepulturas." 137

Vemos na teoria viquiana que, após a captação dos auspícios divinos, são instituídas as leis de culto, são celebradas as uniões e os casamentos solenes e são sepultados os mortos. Esses princípios podem ser encontrados nos primeiros capítulos do Gênesis: na fase adâmica, Deus providencia uma ajudadora idônea ${ }^{138}$ para o homem, Caim se casa e assim o fazem os descendentes de Adão e Caim. Os gigantes e homens de renome aparecem por volta desse período, quando é registrada, no capítulo 4 do Gênesis, a presença da cidade (Enoque) fundada por Caim; podemos vislumbrar os possíveis homens de renome, nas figuras que a bíblia chama de "pai" ${ }^{139}$, identificando-os pelos nomes: "Jabal, o pai dos que habitaram em tendas e têm gado”, “Jubal, o pai dos que tocam harpa“. O texto bíblico fala também do sepultamento dos mortos na era adâmica, especificando as descendências de Adão e de Caim $^{140}$, em que ficam implícitas as uniões e casamentos solenes bem como o sepultamento de antepassados que serão lembrados por laços familiares ou por grandes feitos heróicos, como as construções de cidades.

“ Onde, tanto em grego como em latim, igualmente, 'filhos da Terra' significou o mesmo que "nobre": e para os latinos "ingenui" significa "nobres", quase como" indegeniti" e mais arrojadamente" ingeniti"; como certamente" indigenae" passou a significar os nativos de uma terra, e "dii indigetes" chamaram-se os deuses nativos, que podem ter sido os nobres das cidades heróicas, que se chamaram deuses." 141

\footnotetext{
${ }^{137}$ Postulado já citado anteriormente.

138 “Não é bom que o homem esteja só; far-lhe-ei uma ajudadora idônea...” - Gênesis 2:18 Bíblia Sagrada

139 “E Ada teve a Jabal; este foi o pai dos que habitam em tendas..” - Gênesis 4:20 - Bíblia Sagrada.

${ }^{140}$ A Bíblia registra, ao citar os descendentes de Caim, a existência de objetos de culto de prováveis festas tribais em Gen 4 : vemos as gerações que se seguem com casamentos, vivendo em tendas, com a criando gado e fazendo utensílios de cobre e ferro. O capítulo 5 de Gênesis descreve a descendência de Adão a partir de Set, o filho da redenção. -Capítulos 4 e 5 de Gênesis -Bíblia Sagrada

141 "Onde, tanto in greco quanto in latino, egualmente, "figliuol della Terra" significò lo stesso che "nobile": ed $a^{\prime}$ latini "ingenui" significano "nobili", quasi "indegeniti" e più speditamente "ingeniti"; come certamente "indigence" restaron a significare $i$ natii d'una terra, e "dii indigetes" si dissero i dèi natii, che debbon essere
} 
“E OS FILHOS DE DEUS (BENEI ELOHIM) VIRAM AS FILHAS DOS HOMENS, etc. (VI, 2). R. Simeon b. Yohai chamou-os de filhos dos nobres: [acrescentando], abominou todos que os chamaram filhos de Deus R. Simeon b. Yohai". ${ }^{142}$

O comentário viquiano referente aos “nobres”, citados em Gênesis 6, pode estar relacionado ao comentário rabínico do Midrash Rabá que coloca os filhos da relação entre filhos dos homens e filhos de Deus - "os valentes e nobres, homens de renome"; os rabinos aludem aos poderosos chefes de tribo ou comunidades que pegavam as virgens e as mulheres casadas $^{143}$ e seriam esses os gigantes pré-diluvianos de que fala Vico, numa referência aos homens que negaram as tradições e prescrições divinas.

"Estes dois axiomas expõem o aparecimento de todo o primeiro gênero humano dividido em duas espécies: uma de gigantes, outra de homens de estatura normal; os primeiros são os gentios e os segundos os hebreus (e a diferença só é explicável por causa da educação ferina de uns e da humana de outros); e, consequentemente, os hebreus tiveram uma origem diferente da dos gentios." 144

Vico aborda com profundidade a relação entre os gigantes ou homens de renome e a formação das civilizações gentílicas; a literatura rabínica também vasculha o assunto há séculos, com o intuito de reforçar a idéia de que a nação judaica é "separada” das demais. Os estudos rabínicos a esse respeito, aos quais Vico parece ter tido acesso, podem ser entendidos

stati i nobili dell'eroiche città, che si appellarono "dei”".- La Scienza Nuova - Lib II Sez IV Cap I - Iconomia Poética - pág 272

142 "E OS FILHOS DE DEUS ( BENE ELOHIM) VIRAM AS FILHAS DOS HOMENS, etc (VI,2). R. Simeon b. Yohai chamou-os de filhos dos nobres: [acrescentando] , abominou todos que os chamaram filhos de Deus $R$. Simeon b. Yohai. ....E ELAS ERAM FORMOSAS (toboth). R.Judan disse: Na verdade tobath (Nota: significando aquela mulher que foi tomada por muitos homens) Midrash Rabbah - Beres. (Genesis) XXVI: 6:5 pág 213

${ }^{143}$ E ELAS ERAM FORMOSAS (toboth). R.Judan disse: Na verdade tobath (Nota: significando aquela mulher que foi tomada por muitos homens) Midrash Rabbah - Beres. (Genesis) XXVI: 6:5 - pág 213

144 "172 Queste due degnità mettono in comparsa tutto il primo gener umano diviso in due spezie: una di giganti, altra d'uomini di giusta corporatura; quelli gentili, questi ebrei (la qual differenza non può essere nata altronde che dalla ferina educazione di quelli e dall'umana di questi); e, 'n conseguenza, che gli ebrei ebbero altra origine da quella c'hanno avuto tutti i gentili." La Scienza Nuova - Lib I - Sez II - Degli Elementi - pág 104 
à luz do trabalho da professora doutora Tiziana Portera ${ }^{145}$, "Os gigantes de Gênesis na literatura hebraica desde a apocalíptica até Abravanel". Por meio dessa obra podemos entrar em contato com as opiniões de diversos filósofos e mestres, dentre os quais Maimon e Abravanel; Vico, ao propor a divisão da humanidade entre "hebreus e gentios" analisa as propostas biológicas, genéticas, psíquicas, políticas e morais dos rabinos a respeito daquilo que a Bíblia define como "gigante”. No trabalho de Portera lemos:

"Outra hipótese é que os gigantes (benei 'elopîm) sejam identificáveis com os descendentes de Set (o filho que Eva teve depois de Caim), em contraposição ao grupo indicado pela expressão "filhas dos homens"- relacionado aos descendentes de Caim. Gen 6:1-4 assinalaria, assim, uma espécie de bifurcação entre a descendência dos Setista e a dos Cainistas. É uma, dentre as interpretações mais antigas e felizes, e, dentre outros, Agostinho a sustenta através da identificação de "filhos de Deus" como um título de eleição e de" filhas de homens" como uma expressão que indica a humanidade em estado de pecado". ${ }^{146}$

A professora Tiziana Portera enxerga a reproposição da estrutura do pecado adamítico do Gênesis 6, em que os Setistas (filhos de Deus) são atraídos “visualmente” pela beleza das filhas dos homens, mudando a natureza do pecado e investindo em Eva como a parte negativa e fortemente voltada aos sentidos (como o da visão); a mulher que dará à luz, fora do paraíso, a Caim e a toda uma descendência pecaminosa, só encontrará redenção quando nascerá Set no lugar de Abel. Portera cita ainda:

"Um filão interpretativo diferente concilia a primeira visão dos filhos de Deus como criaturas divinas, identificando-as com os homens", não se tratando, porém, de semideuses; os super-homens a que alude não correspondem aos semideuses que povoam a mitologia grega.. Os "nefelins" coincidem, de acordo com essa leitura, com

\footnotetext{
145 "I giganti del genesi nella lettura ebraica dall'apocalittica ad Abravanel" - Tiziana Portera - Doutora em Filosofia Hebraica, Faculdade de Litras e Filosofia, Universidade dos Estudos de Palermo, Departamento de Civilização Euro-Mediterraneas e de Estudos Clássicos, Cristãos, Bizantinos, Medievais, Humanísticos Officina di Studi Medievali, via del Parlamento 32, 90132 Palermo.

${ }^{146}$ I giganti del genesi nella lettura ebraica dall'apocalittica ad Abravanel” - Tiziana Portera- Pag 59 .
} 
os reis das dinastias que, como dépotas orientais, criavam haréns reais com a força, praticando seqüestros indiscriminados", ${ }^{147}$

No Midrash Rabá de Gênesis 6:6, na página 213 lemos:

“R. Shimon b. Johai os chamava 'filhos de juizes'. R. Shimon b. Johai amaldiçoa todos aqueles que os chamam 'filhos de Deus' [...] E por que [a Escritura] os chama 'filhos de Deus'? Porque viveram longamente sem dores nem sofrimentos. R. Hanah em nome de R. Josê disse: Porque assistiram as órbitas e o caminho dos planetas. Os nossos mestres dizem: Porque pegaram a parte deles e aquela das gerações que vieram depois deles".

Devido à origem etimológica incerta do termo, encontramos, na literatura judaica, várias interpretações para os nefelins, que acabam influenciando a exegese pós-bíblica. Uma das interpretações julga os gigantes como poderosos e arrogantes, detentores de poder e conhecimento; a outra, explica a origem da raiz da palavra nefelim - $n p l($ naphal $=$ cair $)$ associando-a a anjos caídos que tiveram filhos com as filhas dos homens, os supostos gigantes das origens do mundo ou "homens famosos" ${ }^{148}$. Podemos confirmar o conhecimento de Vico quanto às especulações filológicas a respeito dos gigantes na seguinte observação:

\footnotetext{
"Os próprios latinos filólogos observam que todos os antigos povos foram ditos aborígenes e a sacra história nos narra terem sido povos inteiros, que se chamaram emeus e zamzumeus, que os doutos da língua santa dizem ser "gigantes", um dos quais foi Nemrod, e os gigantes antes do dilúvio, a mesma história sagrada os define "homens fortes, famosos, potentes do século." 149
}

\footnotetext{
${ }^{147}$ Os versículos bíblicos, modificados e reciclados, apresentam imagens e dados encontrados nos textos ugaríricos e acádicos que circulavam no tempo dos patriarcas, dentre os quais a Epopéia de Gilgamesh. - I giganti del genesi nella lettura ebraica dall'apocalittica ad Abravanel" - Tiziana Portera- Pag 59 .

148 "I giganti del genesi nella lettura ebraica dall'apocalittica ad Abravanel" - Tiziana Portera - Pág 61

149 “371 Gli stessi latini filologi osservano che tutti gli antichi popoli furon detti aborigini e la sagra storia ci narra esserne stati intieri popoli, che si dissero emmei e zamzumei, ch'i dotti della língua santa spiegano "giganti" um' de quali fu Nebrot; e i giganti innanzi il dilúvio la stessa storia sagra gli diffinisci "uomini forti,
} 
A história dos hebreus foi e é contada e estudada levando em consideração a filologia, que passa a ser a ferramenta adotada por Vico para a dedução da história dos latinos.

"E, fixando-se por longo tempo e sepultando seus antepassados, começaram a fundar e dividir as terras, cujos senhores foram chamados "gigantes" (que em grego soa "filhos da terra", isto é, descendentes de sepultados), e foram reputados nobres, achando - nesse momento inicial do estado das coisas - e arrazoando com idéias justas - que a nobreza vinha por serem gerados com o temor da divindade; e dessa maneira humana de gerar chamou-se "geração humana", para significar a ramificação das casas em tantas famílias, e por tal geração, vieram as primeiras "gentes",. 150

Vico extrai suas verdades analisando o texto sagrado à maneira dos rabinos que encontram justificativas científicas embutidas nas palavras para explicar o que foi relatado numa linguagem “comovida e perturbada”. A preocupação do filósofo italiano em estabelecer o vínculo entre a fábula e a história é semelhante à dos grandes pós-talmudistas da Idade Média como Abravanel: ambos trabalham, unindo conhecimentos clássicos à profundidade da transmissão hebraica e alternam o estilo demonstrativo ao midrashico-talmúdico. A teoria viquiana e a literatura hebraica medieval englobam componentes filosóficos ao comentário bíblico, sem perder de vista a finalidade ético-religiosa e as intenções exegéticas. ${ }^{151}$

Vico encontra na literatura judaica o suporte científico para extrair a história e a ciência do mito e da fábula. Ao dividir a humanidade entre hebreus e "gentes”, o capítulo 6 do Gênesis foi profundamente investigado por Vico. A teoria viquiana engendra a dinâmica dos fatos em que os descendentes dos filhos de Noé estabeleceram as civilizações que conhecemos e conservaram a prática dos três costumes desde os tempos adâmicos: tal prática

famosi, potenti del secolo” - La Scienza Nuova - Lib II - Proleg.Cap.III - Del dilúvio universale e de’ gigantipag 169

\footnotetext{
${ }^{150}$ La Scienza Nuova - “Idea dell’opera” - pág 14

${ }^{151}$ Sintetizamos o comnetário de Tiziana Portera dedicado à obra de Abravanel "Commentaire du récit de la création. Genèse 1:1 à 6:8. Perouch 'al ha-Torah-Beréchit, traduit de l'hébreu par Yéhouda Schuffers, Lagrasse, Verdier, 1999, pp. 520-521.
} 
coloca em evidência o caráter sociável do homem que prossegue fundando religiões, casandose e sepultando seus mortos. O homem rejeita a vida solitária, errante e ferina e, naturalmente, pratica as regras de vida social.

"Concluímos tudo o que se expôs com relação ao estabelecimento dos princípios desta ciência, que são providência divina, moderação das paixões com matrimônios e imortalidade das almas com as sepulturas; e os homens praticam isso como regra de vida social." 152

\section{4 A história se desenvolve por fases}

"Onde esta Ciência descreve ao mesmo tempo uma história ideal eterna, sobre a qual correm em tempo as histórias de todas as nações, nos seus surgimentos, progressos, estados, decadências e fins." 153

Vico acredita que os ricorsi acontecem toda vez que há a perda de memória do passado: o homem, sem raízes, passa a ser o artífice da própria história. Na fase adâmica, o tempo da história ainda não teria acontecido: Vico diz ser Adão um príncipe de um reino cujo rei seria aquele que lhe teria dado o fôlego de vida e a quem Adão dedicaria reverência. A transgressão do comando "não comerás da árvore do conhecimento do bem e do mal”, à qual se segue a sentença "no dia em que dela a comerdes certamente morrerás," pode ter gerado as primeiras noções sobre ética, filosofia e direito; essas noções foram captadas numa linguagem adâmica, entendida como ideal na medida em que não se serve de instituições. $\mathrm{O}$

\footnotetext{
152 "360 Conchiudiamo tutto ciò che generalmente si è divisato d'intorno allo stabilimento de' princìpi di questa Scienza: che, poiché $i$ di lei principi sono provvedenza divina, moderazione di passioni co' matrimoni e immortalità dell'anime umane con le seppolture; e 'I criterio che usa è che ciò che si sente giusto da tutti o la maggior par te degli uomini debba essere la regola della vita socievole." - La Scienza Nuova - Lib I Sez IV Del Método - pág 157

153 “349 Onde questa Scienza viene nello stesso tempo a descrivere una sto ria ideal eterna, sopra la quale corron in tempo le storie di tutte le nazioni ne' loro sorgimenti, progressi, stati, decadenze e fin"i.- La Scienza Nuova - Lib I Sez IV - Del Metodo - pág 154
} 
princípio religioso que desencadeia o processo civilizatório, isto é, a história, existe num lugar bíblico de desequilíbrio entre as forças do bem e do mal.

"Então disse o Senhor Deus: Eis que o homem é como um de nós, sabendo o bem e o mal; para que não estenda a mão e tome também da árvore da vida, e coma e viva eternamente, o Senhor Deus, pois, o lançou fora do jardim do Éden, para lavrar a terra de que fora tomado." 154

Um dos comentários rabínicos diz:

"A história de Adão é a história da humanidade, de todos nós: sua glória, suas dádivas divinas e seu potencial imensurável. Uma única tentação, à qual ele não soube resistir [...] foi, de fato, uma bênção oculta. Apesar de todo homem sonhar com o paraíso perdido, a história da humanidade e todo o propósito da Criação só se iniciaram, de fato, quando Adão e Eva deixaram o Jardim do Éden. Antes de desobedecer à ordem divina, Adão conhecia a Verdade, estava acima das paixões terrestres e dos impulsos que não tinham o poder de perturbar a clareza de sua mente. O Zohar ${ }^{155}$ afirma que existia até então um equilibrio perfeito entre as forças do bem e do mal. ${ }^{156}$

A quebra relacional inaugura, portanto, o primeiro “corso storico", baseado na graça, com a qual Adão pode se religar a Deus e continuar vivo; enxergamos nessa fase a primeiríssima idade divinatória viquiana, em que o primeiro poeta-teólogo adivinha os auspícios divinos para que prossiga sua caminhada numa terra não mais paradisíaca. O poeta teólogo que comunica o conteúdo de seu dicionário mental inicia, assim, o processo de conservação da memória histórica sobre a qual os judeus fundam sua identidade de povo.

\footnotetext{
${ }^{154}$ Gen 3:22:-23 - Bíblia Sagrada

155 O Sefer ha-Zohar - o Livro do Esplendor - É a obra principal e mais sagrada da Cabalá, a dimensão mística do judaísmo. - Disponível em: www.morasha.com.br. Acesso Dez/2006

156 “Práticas Enganadoras: Torá e Ética nos Negócios” - Parashát Bereshit - Comentário inspirado pelo Dvar Torá de Rabi Yoel Domb sobre Ética nos Negócios - Disponível in: www.netjudaica.com.br . Acesso em set/2006.
} 
Na Parashat - o microcosmo da história - enxergamos as três fases de que fala Vico: a primeira fase divinatória é representada por Adão fora do paraíso; a segunda apresenta cidades, homens de renome e possíveis sacerdotes como Enos e a terceira, que sucumbe com o dilúvio, coloca os homens como "homens", isto é, nem deuses, nem heróis. Na metafísica della mente de Adão, o livre-arbítrio o acompanha e o dirige para as escolhas que determinarão o primeiro princípio religioso cultual: seus filhos, Caim e Abel levam ofertas queimadas ao Senhor ${ }^{157}$. Os primeiros lavradores e pastores da terra oferecem sacrifícios a Deus para serem aceitos, com a condição de que façam e escolham o bem. Os usos e costumes da fase heróica adâmica são vistos tanto nas atitudes de Caim e Abel de cultuar como na prática de casamentos e alianças: Caim conhece sua mulher e edifica a provável primeira cidade, Enoque. Com a cidade, vislumbra-se uma comunidade, com leis, ritos e líderes; os cultos rituais são estabelecidos a partir do repasse dos auspícios do Deus de quem tomaram conhecimento por Adão ${ }^{158}$.

De Adão até Enoque, encontramos então uma idade divina, no sentido viquiano da expressão: a religião e o direito já estavam presentes antes da formação das cidades e foram registradas possivelmente por transmissão oral ou por caracteres que precedem o hebraico e que, de alguma maneira expressaram o conteúdo do dicionário mental característico da mente humana. Na fase heróica, os homens estabelecem relações de convivência que incluem rituais e feitos atribuídos a homens de renome; a simbologia, relativa aos rituais aceitos pelo grupo, define um tipo de linguagem poética que relata os fatos vividos na forma de mitologias. Comparando a vida de Noé com a dos gigantes e homens de renome, o Midrash Rabá pode nos dar uma demonstração da presença das idades viquianas na fase adâmica:

"R.Judah diz: Isso significa três gerações [...] de Enos, do Dilúvio e da Separação (de línguas). R. Nehemiah diz: durante a geração de Enos ele não passava de uma criança." 159

\footnotetext{
${ }^{157}$ Capítulo 4 de Gênesis - Bíblia Sagrada

${ }^{158}$ A Bíblia registra, quando registra os descendentes de Caim, a existência de objetos de culto de prováveis festas tribais. Gen 4 decreve a genealogia de Caim, as gerações que se seguem com casamentos e vivência em tendas, com a criação de gado e o feitio de utensílios de cobre e ferro.

159 "R. Judah said : It means trhough three generations[...] of Enosh, the Flood and the Separation ( of tongues). R. Nehemiah said: during the generatin of Enosh he was but a child”. - Midrach Habbah - pag.209
} 
O comentário rabínico apresenta um Noé justo nas suas gerações por ter escolhido viver debaixo da graça; tendo vivido 950 anos, teria passado por diversas gerações. Na época do dilúvio, aos 650 anos, Noé teria sido justo não só na sua geração como também nas anteriores e nas posteriores. O longevo Noé sobrevive a três gerações: aprende a ser justo ainda na geração de Enos, convive com heróis e homens de renome (como Jubal, Jabal, por exemplo) e presencia a decadência da civilização corrupta e violenta, que termina por ocasião do dilúvio; por ter sido poupado, garante a sobrevivência da cultura hebraica e sobrevive a mais uma geração - sendo o novo Adão do ricorso histórico pós-diluviano. A figura de Noé, em sua longa vida, além de achar graça, sobrevive às águas do dilúvio como um verdadeiro herói e Sem, optando por seguir a tradição do pai, inaugura a civilização hebraica (mais tarde judaica): o relato "fantástico" é repassado pela memória judaica que consegue sobreviver por meio de Noé. Com Noé, inicia-se um ricorso storico para os judeus e o primeiro corso para a humanidade gentílica.

Por meio do verum factum, Vico descreve os fatos da história, certificando-se da presença dos pressupostos eternos e universais identificados na fase adâmica registrada na Torá. O relato bíblico registra fatos acontecidos em séculos, provavelmente sintetizados pela dinâmica da conservação da mensagem residual; com os pressupostos identificados por Vico podemos visualizar as idades viquianas (divina, heróica e humana) representadas nas palavras: filhos de Deus, homens de renome e filhos dos homens.

"Os autores da humanidade gentílica devem ter sido homens das raças de Cam, e mui prontamente, de Jafé, e finalmente de Sem, os quais, uns após outros, aos poucos renunciaram à verdadeira religião do pai comum, Noé." 160

Analisando o texto bíblico segundo os axiomas viquianos podemos deduzir que Noé e seus três filhos sobrevivem ao dilúvio levando consigo a memória da tradição adâmica (que poderiam aceitar ou rejeitar) e agirão de acordo com as características intrínsecas que levarão os homens a empreender um começo civilizatório que se caracteriza pela presença da religião, seguida dos casamentos solenes e das sepulturas; vemos também que a capacidade de se

160 La Scienza Nuova - Lib II-Cap I- Della sapienza generalmente - pág 166 
comunicar, o caráter sociável, o livre-arbítrio e o senso comum aparecem como “ingredientes” que acompanham os homens, conduzindo-os a estabelecer princípios de vida em comum em diferentes lugares e em qualquer tempo. A análise de Vico parece ter levado em conta os estudos judaicos a respeito dos gigantes (heróis, poderosos e rebeldes - presentes nas lendas e fábulas de todos os povos), permitindo que o fato fosse extraído da lenda, complementando alguns conceitos naturalistas e fazendo surgir novas visões sobre a história, a linguagem e a estética.

\section{5 A linguagem é o fenômeno que organiza o mundo}

Com observações filosóficas e filológicas que nos fazem vislumbrar um início civilizatório assentado na metafísica do mito, a teoria viquiana apresenta o ser humano inserido numa realidade social em que o uso da linguagem ${ }^{161}$ em função da história permite que as coisas aconteçam. As coisas ${ }^{162}$ - acontecidas e contadas num tempo obscuro - são coletadas e analisadas por Vico do particular para o universal: o filósofo parte da metafísica de Deus para a metafísica do homem fazendo com que os fatos, relatados em linguagem histórica, se transformem em verdades através do verum factum.

Para comprovar que o fato se converte no verdadeiro, o método experimental de Bacon é eleito por Vico como o mais adequado ${ }^{163}$ pois “foge das verdades generalizadas e persegue as regras de comportamento que podem explicar os fenômenos de modo que não estejam tão distantes da realidade”. ${ }^{164}$ Assim como Bacon, Vico defende a idéia de que é

\footnotetext{
161 Ao considerarmos a linguagem como um fenômeno que antecede a palavra, naturalmente a vinculamos ao seu uso: linguagem, fora do seu caráter social, se reduz à capacidade de produzir sons e imagens

${ }^{162}$ Vico se refere "às coisas” para explicar os elementos que formam o mundo das nações: “[...] o qual, pelos seus elementos é formado por todas as coisas que a pintura representa com hieróglifos.” - La Scienza Nuova “Spiegazione della Dippintura..” - pág. 5

163 La Scienza Nuova - Lib I Sez IV -Del método - pág 157

${ }^{164}$ Bacon, o último dos quatro filósofos que impactaram Vico (os outros três são Platão, Tácito e Grozio), pode ter sido decisivo para a formulação genial da teoria viquiana sobre o mito: Bacon acredita que estejam presentes na mente humana certas convicções ou pré-conceitos ( $i d o l a$ ), que limitam o conhecimento objetivo da realidade; os pré-conceitos deformam a realidade e impedem a visão efetiva dos fatos. ( Diego Fusaro). Disponível em: http://www.filosofico.net/bacon.htm Acesso em ago/2006.
} 
possível re-elaborar com a razão - e com um método - os dados recolhidos na história natural. O filósofo inglês acredita que para desvendar o saber humano é necessário conhecer as idéias dos homens em todos os tempos e o método viquiano pretende conhecer as idéias dos homens contidas na metafisica della mente; ambos preconizam que os fatos, relatados em linguagem histórica, transformam-se em verdades quando a história (que se funda na memória), a poesia (que se funda na imaginação) e a filosofia (que se funda na razão) revelam o saber humano. Vico se serve do modelo judaico de aculturação, do modo rabínico de argumentar e da metodologia de Bacon, apoiando-se em "palavras” para desvendar a história das idéias dos homens. Apostando na "linguagem”, Vico e os rabinos, por meio da hermenêutica e da filologia, provam que a história se faz também com palavras. Na literatura judaica, o papel da linguagem na formação e organização do mundo, desde o fiat, é fundamental; para Vico, a fantasia criadora, que se manifesta por diferentes e progressivas formas de expressão, é a responsável pela formação das civilizações da humanidade.

Vico constata a presença de um padrão religioso no processo de organização jurídica dos povos que foi revelado em Gênesis; nesse livro podemos encontrar também um registro de como pode ter sido a exclamação com a qual o homem adâmico identificou seu Deus: $E l$ parece ser o vocábulo que dá origem à língua dos hebreus ${ }^{165}$, assim como a exclamação “ius”, teria dado origem à língua latina. Vico avalia o processo mental - a metafísica della mente do homem adâmico e do bestione e define um complexo e discutível sistema filológico para provar que a ius, assim como El, surgiu da observação do céu:

"Com o nascimento dos caracteres poéticos e das línguas, nasceu a gius, ou dito "ious" para os latinos, e para os gregos diaión - que mais adiante poderá ser explicado como "celeste", ou dito de Diós; [...] Porque universalmente, por todas as nações gentílicas o céu foi observado da mesma maneira, ou seja, com o aspecto de Jove de quem se recebem as leis e comandos, tidos como auspícios; o que demonstra que todas as nações nasceram sob a persuasão da divina providência." 166

\footnotetext{
165 “Os primeiros registros da comunicação do homem com Seu Criador nós o encontramos no livro de Gênesis (escrito em hebraico), e ele é conhecido por EL. EL é o mais primitivo nome semítico, e sua raiz provavelmente significa "Forte". - Disponível em: http://www1.uol.com.br/biblia/revista/edicao10/aleluia.htm.Acesso jan/2007.
} 
Esse texto nos dá um exemplo do esquema filológico utilizado por Vico, que se assemelha ao modo rabínico de argumentar. Tal modo pode ser explicado pelo Professor Moacir Amâncio, no seu livro “O Talmud” - (SP, 1995 - Ed. Iluminuras) com o termo dvr: dependendo da escolha da vogal a ser colocada entre as consoantes, os significados serão alterados.

"Escolhe-se o seguinte versículo ao acaso ( Gênesis XVI,4): "Eis que foi a palavra do Eterno, (devar - dvr Elohim) a ele, dizendo:[...] Atente-se aqui para o termo dvr, davar, palavra, medaber, eu falo, tu falas, ele fala. Mas dvr, davar, também significa "coisa"”. 167

Com esquemas filológicos semelhantes, Vico deduz que a "lógica” expressa a idéia, isto é, a Lógica deriva de logos e na língua latina significava "fábula", que deu origem à palavra italiana "favella" (falar)"; e a linguagem mental (muda) dos inícios é a própria idéia que busca o significado das coisas em que "logos significa tanto idéia como palavra. Esse tipo de observação levou o filósofo a investigar a origem de tudo na "ius" e o conduziu a tecer as analogias entre os significados de "gigantes" e "nobres" de que falamos anteriormente; inúmeros outros exemplos podem ser encontrados no capítulo da Ciência Nova que trata da Lógica Poética. GV trabalha como os rabinos, no sentido de desvendar o fato usando a razão para entender as palavras que os poetas usaram para "dar sentido e paixão às coisas insensatas" ${ }^{168}$.

\footnotetext{
166 " 473 Con tal primo nascere de' caratteri e delle lingue nacque il gius, detto "ious" da' latini, e dagli antichi greci diaión - che noi sopra spiegammo "celeste", detto da Diós; onde a' latini vennero "sub dio" egualmente e "sub Iove" per dir "a ciel aperto" - e, come dice Platone nel Cratilo, che poi per leggiadria di favella fu detto díkaion. Perché universalmente da tutte le nazioni gentili fu osservato il cielo con l'aspetto di Giove, per riceverne le leggi ne' di lui divini avvisi o comandi, che credevan esser gli auspici; lo che dimostra tutte le nazioni esser nate sulla persuasione della provvedenza divina". - La Scienza Nuova - Lib II Sez II Cap VI Logica Poetica - pag . 234

167 “O Talmud” - Moacir Amâncio - SP, 1995 -Ed. Iluminuras - pág . 89.

168 "186 Il più sublime lavoro della poesia è alle cose insensate dare senso e passione"- La Scienza Nuova -Lib I - Sez II - Degli Elementi - pág 107
} 
$\mathrm{Na}$ teoria viquiana, o homem selvagem aparece sensibilizado diante da suposta divindade e, perturbado, emite sons de espanto: à medida que organiza as idéias produzindo sons para representá-las, o homem organiza também o mundo sobre o qual realizará seus pactos e alianças. As divindades, que auspiciam as leis, povoam os panteões num momento de "sapienza riposta": YWTH aparece na era mosaica, quando surgem também os tantos Joves e as epopéias e relatos que conhecemos. A "Lógica, que deriva de logos" e que antes e apropriadamente significou fábula e, portanto, continha a idéia expressa em palavras, dá forma e posiciona as coisas:

"É necessário que exista na natureza das coisas humanas uma língua mental, comum a todas as nações, a qual de maneira uniforme contenha a substância das coisas e atos da vida humana em sociedade, e a explique com diferentes modificações de acordo com os diversos aspectos das coisas;" 169

A linguagem (a língua) contém a substância das coisas e os atos da vida em sociedade, e acontece na forma de sinais que comunicam as necessidades comuns da vida. As substâncias e os atos da vida são a própria história. Vico elabora sua “arte critica” e dá o passo decisivo para que tal atitude, polêmica e analítica, somada às intensas investidas arqueológicas de sua época, fizessem com que a história se elevasse à categoria de disciplina no cenário científico do século XVII. Os monumentos e ruínas da antiguidade não eram suficientes para “contar” a história sem a interpretação da "língua” que continha a substância das coisas e dos atos da vida dos nossos antepassados:

“[...] as grandes ruínas da antiguidade, inúteis até agora para a ciência porque jaziam esquálidas, inacabadas e deslocadas, vêm à luz nítidas, compostas e localizadas nos seus devidos lugares." 170

\footnotetext{
169 "161 E' necessario che vi sia nella natura delle cose umane una lingua mentale comune a tutte le nazioni, la quale uniformemente intenda la sostanza delle cose agibili nell'umana vita socievole, e la spieghi con tante diverse modificazioni per quanti diversi aspetti possan aver esse cose; siccome lo sperimentiamo vero ne' proverbi, che sono massime di sapienza volgare, l'istesse in sostanza intese da tutte le nazioni antiche e moderne, quante elleno sono, per tanti diversi aspetti significate". A Ciência Nova - Libro I Sez.II Degli elementi- pág 101
} 
As "provas filológicas, que aparecem imediatamente depois das provas filosóficas, afirmam a autoridade com a razão e a razão com a autoridade." 171 Com observações filosóficas e filológicas que nos fazem vislumbrar um início civilizatório fundamentado na metafísica do mito, a teoria viquiana apresenta o ser humano inserido numa realidade social na qual o uso da linguagem ${ }^{172}$ em função do mito permite que as coisas aconteçam. Os rabinos dissecaram a Torá e Vico parece ter se aprofundado nela e em outras tradições para, assim como os rabinos, fazer emergir o fato histórico.

Antes de Vico, a história dos gentios não possuía “incominciamento” e, independentemente da especulação religiosa de que parte, sua teoria apresenta o homem, desde os inícios, inserido numa realidade social, em que o uso da linguagem em função do mito possibilita a revelação do objeto específico do discurso histórico. A teoria viquiana não aceita o cógito como o início da existência humana e aposta na fantasia criadora, ou seja, na poesia e na palavra para resgatar a história dos tempos obscuros. È na linguagem

\begin{abstract}
“lugar de ordem no mundo, [...] que a percepção de um caos irredimível, ou só redimido através de um sacrificio que consagra sem ilusão alguma a impotência humana - e tal é a experiência trágica - nos dá, através de balbuciamentos, o que foi outrora um fúnebre, mas exultante esplendor. ${ }^{173}$
\end{abstract}

\footnotetext{
170 “357 Sesto, i grandi frantumi dell'antichità, inutili finor alla scienza perché erano giaciuti squallidi, tronchi e slogati, arrecano de' grandi lumi, tersi composti ed allogati ne' luoghi loro”. - La Scienza Nuova - Lib I Sez IV - Del método - pág .156

171 “359 Le quali pruove filologiche servono per farci vedere di fatto le cose meditate in idea d'intorno a questo mondo di nazioni, secondo il metodo di filosofare del Verulamio, ch'è «cogitare videre»; ond'è che, per le pruove filosofiche innanzi fatte, le filologiche, le quali succedono appresso, vengono nello stesso tempo e ad aver confermata l'autorità loro con la ragione ed a confermare la ragione con la loro autorità.”- La Scienza Nuova - Lib I Sez IV -Del método - pag 157

${ }^{172}$ Consideramos linguagem os momentos anteriores à palavra.

${ }^{173}$ George Steiner - Cap. “ Do trágico e da tragédia” - pág . 28
} 


\section{CONCLUSÃO}

Giambattista Vico, assim como os rabinos, parte da metafísica de Deus para a metafísica do homem e apóia-se no verum factum para catalogar os acontecimentos reais relatados em linguagem mitológica. GV elabora, portanto, uma teoria sobre o começo da humanidade gentílica que se contrapõe ao método dedutivo, predominante em sua época, porque coloca a religião e o fenômeno lingüístico na base do processo civilizatório. Considerando como um documento histórico o relato do Dilúvio Universal, registrado no capítulo 6 de Gênesis, as colocações do filósofo napolitano baseiam-se nos fundamentos da filosofia clássica greco-romana e judaica, apresentando muitas afinidades com as interpretações rabínicas relativas ao episódio, também considerado um documento histórico conservado pelas tradições orais e verbais judaicas. Da mito-poética das lendas e fábulas dos povos da antiguidade, Vico e os rabinos extraem o fato histórico que revela o conceito amalgamado de religião e direito - crença e lei - inicialmente desprovido de elaboração intelectual e repleto de intuição, emoção e impulso. Tal conceito, ao ser expresso e processado, coloca a poesia, a linguagem e o saber espontâneo - que Vico chama de fantasia criadora - num lugar pioneiro de geradores de cultura.

Vico e os talmudistas dão corpo e forma ao relato mitológico, apoiando-se no fenômeno lingüístico-religioso e na teoria da graça. O método de verificação científica apresentado por Vico, aproxima-se do modo analítico de interpretar e argumentar dos rabinos que, sem utilizar ferramentas numéricas - matemáticas e geométricas - embasa e organiza as hipóteses e as teses, enriquecendo-as de colocações históricas, sociais, psicológicas, filosóficas e filológicas, buscando justificativas nas próprias ciências humanas. Analisando o texto bíblico segundo os axiomas viquianos podemos deduzir que Noé e seus três filhos sobrevivem ao dilúvio levando consigo a memória da tradição adâmica (que poderiam aceitar ou rejeitar) e agirão de acordo com as características intrínsecas que levarão os homens a empreender um começo civilizatório que se caracteriza pela presença da religião, seguida dos casamentos solenes e das sepulturas; vemos também que a capacidade de se comunicar, o caráter sociável, o livre-arbítrio e o senso comum aparecem como “ingredientes” que acompanham os homens, conduzindo-os a estabelecer princípios de vida em comum em 
diferentes lugares e em qualquer tempo. A análise de Vico parece ter levado em conta os estudos judaicos a respeito dos gigantes (heróis, poderosos e rebeldes - presentes nas lendas e fábulas de todos os povos), e permitiu que o fato fosse extraído da lenda, complementando alguns conceitos naturalistas e fazendo surgir novas visões sobre a história, a linguagem e a estética.

A organização civil da humanidade acontece numa fase viquiana conhecida como divina e se desenvolve para as fases heróica e humana sucessivamente; as três fases estão presentes na Torá e nas lendas dos povos da antiguidade e, notadamente, no livro de Gênesis, aparecem em diferentes momentos históricos, comprovando a teoria viquiana relativa aos corsi e ricorsi. No livro de Gênesis encontramos também os fundamentos que servirão de base para a elaboração do conceito viquiano sobre a graça, responsável pela divisão da humanidade entre hebreus e gentios, que dará margem às conjecturas relativas à existência de gigantes no tempo do dilúvio.

Tanto a proposta viquiana sobre o começo das civilizações como os comentários rabínicos sobre o dilúvio universal revelam ser a linguagem o fenômeno que organiza o mundo e desencadeia a história. 


\section{ANEXO A}

\section{Giambattista Vico - La Scienza Nuova - “Idea dell’opera” - pg 13/14/15}

"Perché truoverassi che le razze, prima di Cam, poi di Giafet e finalmente di Sem, elleno, senza la religione del loro padre Noè, ch'avevano rinniegata (la qual sola, nello stato ch'era allor di natura, poteva, co' matrimoni, tenergli in società di famiglie) - essendosi sperdute, con un errore o sia divagamento ferino, dentro la gran selva di questa terra, per inseguire le schive e ritrose donne, per campar dalle fiere (delle quali doveva la grande antica selva abbondare), e, sì sbandati, per truovare pascolo ed acqua, e, per tutto ciò, a capo di lunga età essendo andate in uno stato di bestie, - quivi, a certe occasioni dalla divina provvedenza ordinate (che da questa Scienza si meditano e si ritruovano), scosse e destate da un terribile spavento d'una da essi stessi finta e creduta divinità del Cielo e di Giove, finalmente se ne ristarono alquanti e si nascosero in certi luoghi; ove, fermi con certe donne, per lo timore dell'appresa divinità, al coverto, coi congiugnimenti carnali religiosi e pudichi, celebrarono i matrimoni e fecero certi figliuoli, e cosi fondarono le famiglie. E, con lo star quivi fermi lunga stagione e con le seppolture degli antenati, si ritruovarono aver ivi fondati e divisi i primi domini della terra, i cui signori ne furon detti "giganti" (ché tanto suona tal voce in greco quanto "figliuoli della terra", cioè discendenti da' seppelliti), e quindi se ne riputarono nobili, estimando, in quel primo stato di cose umane, con giuste idee, la nobiltà dall'essere stati umanamente eglino generati col timore della divinità; dalla qual maniera di umanamente generare e non altronde, come provvenne, così fu detta l'"umana generazione", dalla quale le case diramate in più così fatte famiglie, per cotal generazione, se ne dissero le prime "genti". Dal qual punto di tempo antichissimo, siccome ne incomincia la materia, così s'incomincia qui la dottrina del diritto natural delle genti, ch'è altro principal aspetto con cui si dee guardar questa Scienza. Or tai giganti, con ragioni come fisiche cosi morali, oltre l'autorità dell'istorie, si truovano essere stati di sformate forze e stature: le quali cagioni non essendo cadute ne' credenti del vero Dio, criatore del mondo e del principe di tutto l'uman genere Adamo, gli ebrei, fin dal principio del mondo, furono di giusta corporatura. Così - dopo il primo d'intorno alla provvedenza divina, e 'l secondo il qual è de' matrimoni solenni - l'universal credenza dell'immortalità dell'anima, che cominciò con le seppolture, egli è il terzo degli tre princìpi, sopra i quali questa Scienza ragiona d'intorno all'origini di tutte l'innumerabili varie diverse cose che tratta". 174

\footnotetext{
${ }^{174}$ Porque acontecera que as raças, primeiro de Cam, depois de Jafé e finalmente de Sem, sem a religião do seu pai Noé, que tinham renegado ( e era a única coisas que,estando eles então num estado natural, podia, com
} 
matrimônios, mantê-los em sociedade de familias) - e tendo se dispersado, errando, isto é, divagando como feras, dentro da grande selva desta terra, para seguir as esquivas e retraídas mulheres, e sobreviver às feras ( que deviam abundar na grande e antiga selva), e por estarem perdidos, procurando pasto e água, ao fim de um longo tempo, reduzidos a um estado animal - e em certas ocasiões seguindo as ordens da providência ( meditadas e encontradas nesta Ciência), sacudidos e assolados por um terrivel susto advindo de crenças e divinidades (do Céu e de Júpiter) por eles criadas, finalmente alguns pararam e se esconderam em certos lugares: onde, parados, com certas mulheres, temendo a divindade captada, abrigados, com relações carnais religiosas e pudicas, celebraram os matrimonios e tiveram certos filhos e assim fundaram as famílias. E, fixando-se por longo tempo e sepultando seus antepassados, começaram a fundar e dividir as terras, cujos senhores foram chamados "gigantes" (que em grego soa "filhos da terra", isto é, descendentes de sepultados), e foram reputados nobres, achando - nesse momento inicial do estado das coisas - e arrazoando com idéias justas - que a nobreza vinha por serem gerados com o temor da divindade; e dessa maneira humana de gerar chamou-se "geração humana", para significar a ramificação das casas em tantas famílias, e por tal geração, vieram as primeiras "gentes. E nesse momento do tempo antigo, assim como começa a matéria, começa também a doutrina do direito natural das gentes, que é outro aspecto por onde se deve observar esta Ciência. E tais gigantes, por razões tanto físicas como morais, descobre-se (além da autoridade das histórias sem registro) que foram de força e estaturas descomunais, porque não caíram nem creram no verdadeiro Deus - que criou o mundo e o príncipe de todo o gênero humano, Adão, - a diferença dos hebreus que, desde o princípio do mundo, foram de corporatura normal. Assim, o primeiro princípio, ou seja, a providência divina, o segundo - os matrimônios solenes e o terceiro, a crença na imortalidade da alma que começou com as sepulturas, são os princípios com os quais, nesta Ciência, se arrazoa sobre as origens das inúmeras e variadas coisas. 


\section{ANEXO B}

\section{Bíblia Sagrada - Gênesis 6: 1-12}

Como se foram multiplicando os homens na terra, e lhes nasceram filhas, vendo os filhos de Deus que as filhas dos homens eram formosas, tomaram para si mulheres, as que, entre todas, mais lhes agradaram.

Então, disse o SENHOR: O meu Espírito não agirá para sempre no homem, pois este é carnal; e os seus dias serão cento e vinte anos.

Ora, naquele tempo havia gigantes na terra; e também depois, quando os filhos de Deus possuíram as filhas dos homens, as quais lhes deram filhos; estes foram valentes, varões de renome, na antiguidade.

Viu o SENHOR que a maldade do homem se havia multiplicado na terra e que era continuamente mau todo desígnio do seu coração;

então, se arrependeu o SENHOR de ter feito o homem na terra, e isso lhe pesou no coração.

Disse o SENHOR: Farei desaparecer da face da terra o homem que criei, o homem e o animal, os répteis e as aves dos céus; porque me arrependo de havê-los feito.

Porém Noé achou graça diante do SENHOR.

Eis a história de Noé. Noé era homem justo e íntegro entre os seus contemporâneos; Noé andava com Deus.

Gerou três filhos: Sem, Cam e Jafé.

A terra estava corrompida à vista de Deus e cheia de violência.

Viu Deus a terra, e eis que estava corrompida; porque todo ser vivente havia corrompido o seu caminho na terra. 


\section{ANEXO C}

Midrash Rabá - Bereshit (Genesis) XXVI: 6:1

AND IT CAME TO PASS WHEN MAN REBELLED- E.V.'BEGAN' (Gen.VI,I)

R.Simon: In trhee places this term is used in the sense of rebellion \{against God\}:They rebelled(huhal) to call upon the name of the Lord(ib.IV,26); AND IT CAME TO PASS, WHEN MAN REBELLED; He\{Nimrod\} rebelled when he was a mighty one in the earth(ib.X,8). An objection was raised: But it is written, And this is what they have rebelled to do ( ib.XI,6)? He replied:\{God\} smote Nimrod's head, exclaiming.......

Midrash Rabá - Bereshit (Genesis) XXVI: 6:5

THAT THE SONS OF GOD ( BENE ELOHIM ) SAW THE DAUGHTERS OF MEN,etc (VI,2).R. Simeon b. Yohai called them the sons of nobles....

Midrash Rabá - Bereshit (Genesis) XXVI: 6:7

THE NEPHILIM WERE IN THE EARTH... THE SAME WERE THE GIBBORIM (E.V. 'MIGHTY MEN') THAT WERE OF OLD (VI, 4). They were called by seven names: Nephilim, Emim, Refaim, Gibborim, Zamzumim, Anakim, and Awim. ${ }^{175}$ Emim signifies that their dread (emah) fell upon all; Refaim, that all who saw them melted (nirpeh) like wax. Gibborim: R. Abba said in R. Johanan's name: The marrow of each one's thighbone was eighteen cubits long. ${ }^{176}$ Zamzumim: R. Jose b. R. Hanina said: They were the greatest of all masters of the arts of war. ${ }^{177}$

\footnotetext{
${ }^{175}$ V. Deut. II, 10 f, 20 f, 23.

${ }^{176}$ Gibborim denotes mighty, great.

177 Th. holds that this does not actually explain the meaning of the word zamzumim, but is a comment on their might. Th. also conjectures that R. Jose connects zamzumim with zamam, to devise, intend, and it implies that owing to their superior military power they could always carry out their schemes.
} 


\section{BIBLIOGRAFIA}

\section{Obras de Vico}

VICO, G. La Scienza Nuova: giusta ed. Del 1744. Bari: Ed.Laterza, 1974.

. Opere: A cura di Fausto Nicolini. Milão: Ric.Ricciardi, 1953.

. Opere filosofiche: A cura di P. Cristofolini. Firenze:Ed.Sansoni, 1977

- A Ciência Nova : Tradução de LUCCHESI, M. Rio de Janeiro:

Ed.Record, 1999.

. De Antiqüíssima italorum Sapientia ex linguae latinae originibus

Eruenda: Liber primus, caput I. (citada por A. Bosi em $O$ ser e o tempo na poesia nota p.198)

\section{Obras sobre Vico}

BADALONI, N. Introduzione a Vico. Firenze: Ed.Laterza, 1984.

MODICA, G. La filosofia del «senso comune comune» in Giambattista Vico».

Roma: Sciascia, 1983

DORFLES, G. L'estética del mito : da Vico a Wittgenstain. Milano: Ed.Mursia, 1968

CROCE, B. La filosofia di G. Vico: Bibliografia Vichiana. Napoli: Ed. Ric. Ricciardi, 1947.

GARIN, E. Vico e l'eredità del pensiero del Rinascimento. Milano: Ed.Villardi, 1947.

BATTISTINI, A. Vico oggi. Roma: Ed. Armando, 1979

MARCHETTI, A. Riscoprire Vico. Roma: Soc.Ed. Dante Alighieri, 1994

VILLA, G. La filosofia del Mito secondo G.Vico. Milano: Ed.frat. Bocca, 1949

SANTOS, V.C. Vico e a ordem de estudos de seu tempo: a ligação entre conhecimento e ética. Campinas: Educ. Soc., vol. 24, n. 85, dez. 2003 
MOMIGLIANO, A. Vico's Scienza nuova: Roman "Bestioni" and Roman "Eroi" History and Theory, Vol. 5, No. Wesleyan University, 1966, pp. 3-23

VICO E LE REPUBBLICHE DEI MERCADANTI . Ist.It. Studi filosofici Aniello Montano (Università di Salerno). Disponível em: <http//www.iisf.it/montano.htm>. Acesso em 26 jul. 2006

SANTOS ,V. C. “Vico e a ordem de estudos de seu tempo: a ligação entre conhecimento e ética”.Disponível em: www.scielo.br/pdf/es/v24n85/a09v2485.pdf. Acesso dez/2006 Centro di Studi Vichiani. Via Porta di massa, 1. 80133, Napoli. Disponível em: $<$ htpp//www.csv.cnr.it/ >

\section{Obras sobre literatura judaica}

La Bibbia: A cura di GIRLANDA A. e outros. Roma: Edizioni Paoline, 1983

Bíblia Sagrada: Tradução de ALMEIDA, J.F. Florida: Ed. Vida, 1990

AMÂNCIO, M. O Talmud . São Paulo: Ed. Iluminuras, 1995

DEL GIGLIO, A. Introdução ao Talmud. São Paulo: Ed. e Livraria Sêfer, 2000

MIDRASH RABÁ : Cap.26 Bereshith-pp.209 a 231

FLAVIO, J. História dos hebreus -. Rio de Janeiro: Ed. CPAD, 1990.

RABIN, C. Ressurgimento da língua hebraica. S.Paulo:Ed. B’nai Brith,1970.

AUSUBEL, N. Conhecimento Judaico. Rio de Janeiro: A.Koogan Editor,1989.

AZRIA,R. O judaísmo : Traduão de Maria Elena O. O. Assumpção. S.Paulo: Ed. EDUSC, 1996

GUTTMANN, J. A Filosofia do Judaísmo. São Paulo: Ed.Perspectiva, 2003.

LEVINAS, E. Do Sagrado ao Santo: Cinco novas interpretações talmúdicas. Rio de Janeiro: Ed. Civilização Brasileira, 2001. 
ALBRIGHT, W.F. The Archaeology of Palestine: A survey of Ancient People and Cultures of the Holy Land . Bungay Great Britain: Richand ClayEd., 1960.

BRIGHT, J. Early Israel in Recent History Writing: A Study in Method .London:SCM Press, 1956.

RAFFALOVITCH, Is. Breve História da Literatura Judaica.Coleção Judaísmo: Adap. por Henrique Iusim. Rio de Janeiro: Graf. Monte Scopus Ltda., 1962.

VILLAMIL DE RADA . Disponível em: <htpp//www.aymara.org/biblio/igr/igr1.html> Acesso em dez/2005.

PORTERA,T. "I giganti del genesi nella lettura ebraica dall'apocalittica ad Abravanel" Disponível em: www.unipa.it/dicem/html/pubblicazioni/pan2003/17.Portera.pdf. Acesso em jul/2006

Hisória Judaica. Revista cultura 200. Disponível em: www.culturajudaica.org.br. Acesso mar/2006

O Midrash Da Criação. Disponível em: www.netjudaica.com.br. $<$ htpp//www.str.com.br/Scientia/origem.htm> . Acesso em set 2005.

Yetzer . Disponível em Disponível in http://penei.org/vocab/vocab-yetzer.shtml. Acesso em set/2006 Acesso em jun/2006

O Sefer Ha-Zohar - o Livro do Esplendor - Disponel em: www.morasha.com.br. Acesso em set/2006

Tradições e Costumes. Por Schlesinger Erma C. Disponível em: $<$ htpp//www.visaojudaica.com.br. Acesso em abril/2006

O vocábulo El. Disponível em: http://www1.uol.com.br/biblia/revista/edicao10/aleluia.htm. Acesso jan/2007

\section{Outras}

NERGAARD, S. La teoria della traduzione nella storia. Milão: Ed. Bompiani, 1993

ROTTA, S. Montesquieu nel Settecento italiano: note e ricerche Disponível em: http://www.eliohs.unifi.it/testi/900/rotta/rotta_montesettit.html. Acesso jan/2007 
STEINER, G. La morte della tragédia. Milano: Ed. Garzanti, 2005.

SCHILLER, J. C. F. Teoria da tragédia: Acerca da razão por que nos entretêm assuntos trágicos. São Paulo: Ed.Herder, 1964. pp. 13 a 27

FUSARO, D. Francesco Bacone. Disponível em: http://www.filosofico.net/bacon.htm Acesso em ago/2006

BOSI, A. O ser e o tempo da poesia. São Paulo: Ed. Cultrix, 1977

ARROJO, R. Oficina de tradução: A teoria na prática. São Paulo: Ed. Ática, 1992.

PAVESE, C. Dialoghi con Leocò . Torino: Ed. Einaudi, 1947. 